\title{
Through Thick and Thin /l \\ Story Space on Rannoch Moor
}

by

Camille Ringrose

A thesis submitted to the Faculty of Graduate and Postdoctoral Affairs in partial fulfillment of the requirements for the degree of

Masters of Architecture

Carleton University

Ottawa, Ontario

(C) 202I, Camille Ringrose 
This thesis proposes a compilation of fictional narratives that reflect on the moor as ground, as an unstable terrain, of burial and wetness, and proposes alternative ways of knowing through literature, folklore and story-telling as a multiverse method of worldbuilding. Can we use stories to design with precision - not as an act of probing for answers, for newness or novelty, but as a form of watching and waiting? Storytelling suggests a movement to look not to the past, or to the future, but to the deepness of the conditions that surround us, weaving together a more complex tapestry towards recuperation and resilience. This research uses a pluralistic approach (research, drawing, mapping, site-studies, stories, etc) to understand and investigate the relationship between storytelling and architectural representation. It tracks, traces, and upends - through thick and thin - notions of geological time, history, literature and lore through a speculative imaginary of Rannoch Moor. 


\section{Acknolwedgements}

A deep thank you to my supervisor Ozayr Saloojee, for joining me on my

journey through the peatbogs of Scotland and providing unwavering guidance and support throughout the way. Thank you for sharing your knowledge and perspective over the past three years.

A warm thank you to Josh, for always being curious, kind, and patient in a year of fog. Sláinte my dear.

To my studio people, who's friendships I will carry with me to the next chapter.

To my parents, who told me to 'stay gold' and nurtured my curiosity.

To the Moor, who shared its secrets and wonders with me.

A special thank you to my Mum and Nini for sharing stories and creating a desire learn about place and what it meant to be of a place. Scotland misses you.

\section{Tapadh Leibh}


Table of Contents

Abstract

Acknowledgements

Table of Contents

List of Figures

Glossary of Enchantment

Chapter i The Context

I.I The Path / Slighe

I.II The Text / Litreachas

I. III The Method / Rian

I.IV The Path

Chapter ii Scotland

II.I The History / Eachdraidh

II.II The Wild

II. III The Vote

II.IV The Estate

II. V The Wetness

Chapter iii The Moor

III.I The Imagination

III.II The Peat

|II. III The Ground

Chapter iv Rannoch Moor

IV.I The Arrival

IV.II The Visit

IV.III The Access

IV.V The Creatures

Chapter v The Stage

V.I The Set

V.II The Curiosities

V.III The Reflection

Chapter iv The Narrative

VI.I The House and the Moor

VI.I The Story

Afterward

Bibliography ii

iii

iv

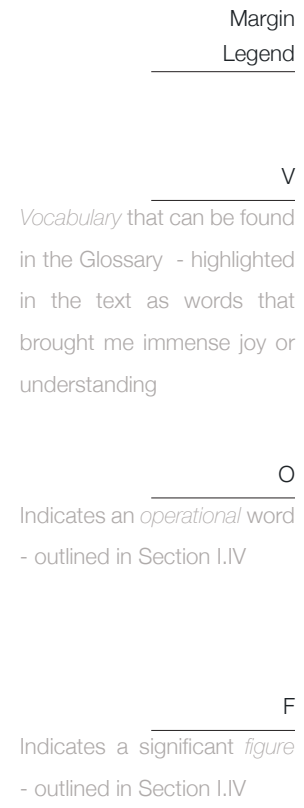




\section{List of Figures}

Figure 1 Buachaille Etive Mòr (The Heardsman), Rannoch Moor, 2020

Figure 2 Literature Mapping / Supporting Literature 4

Figure 3 Rionnach Moaim, Rannoch Moor, 2020

Figure 4 Dramatic Landscape, Rannoch Moor $2020 . \quad 9$

$\begin{array}{ll}\text { Figure } 5 \text { Collage: Characters of the Highlands } & 10\end{array}$

Figure 6 "Surveying Party by Kinloch Rannoch." Loch Rannoch, 1749. British Library . London. 13

Figure 7 Below: The Berkeley Hunt, 1842: The Death.

Figure 8-11 Policies of union, property, and access. 20

Figure 12 Wetness, Rannoch Moor 2020.

Figure 13 Waterway Mapping of Rannoch Moor and Scotland 23

Figure 14 Thin Places. Rannoch Moor 2020. 24

$\begin{array}{ll}\text { Figure } 15 \text { Operations of Peat } & 28\end{array}$

Figure 16 Operations of Peat: Mini Bog Model 30

Figure 17 Timeline of Peat, Scotland and Rannoch Moor 31

Figure 18, 19 Rannoch Moor, $2020 \quad 32$

Figure 20, 21, 22 Site Photos. Rannoch Moor, 2020

Figure 23 The Ways of Rannoch Moor 36

Figure 24, 25, 26 Railway and Rannoch Moor Station. Rannoch Moor 2020. Railway Track Assemblage Diagram 37

$\begin{array}{ll}\text { Figure } 27 \text { The Boundaries of Rannoch Moor } & 38\end{array}$

Figure 28, 29 Wetland Moor Ground Cover, Peat Coverage Map Rannoch Moor. 39

Figure 30 Rannoch Moor Lookout, 2021

Figure 31, 32 Cameron, Dominique. Moor Series. 2020 (Rannoch Moor), 41

Figure 33 Golden Hour, Rannoch Moor $2020 \quad 42$

Figure 34 Surface Engagement Sketches $\quad 43$

Figure 35 Flora and Fauna Sketches, Rannoch Moor 44

Figure 36 Rannoch Moor Pluriverse of Relations 45

Figure 37 Speculative Section, Rannoch Moor. $\quad 46$

$\begin{array}{ll}\text { Figure } 38 \text { Collage Draft } & 48\end{array}$

Figure 39 Operations and Figures $\quad 50$

Figure 40 Collage No. 1 - Carbon Landscapes

Figure 41 Collage No. 2 - Lore and Bog Bodies 53

Figure 42 Collage No. 3 - Sunken Foundations of Place $\quad 54$

Figure 43 Collage No. 4 - "There is no wild land in Scotland" 55

Figure 44 Collage No. 5 - The Trophy Room 56

Figure 45 Collage No. 6 - Shoring Up $\quad 57$

Figure 46 Collage No. 7 - Right to Roam 58

Figure 47 Collage No. 8 -Unsettled $\quad 59$

Figure 48 -Collage No. 9 - Memory Terraforming $\quad 60$

Figure 49 Sunken House $\quad 65$

$\begin{array}{ll}\text { Figure 50 The Register } & 67\end{array}$

Figure 51 Drawing No. 1 A Light Beckons $\quad 71$

Figure 52 Drawing No. 2 The Moor is a Trickster $\quad 73$

Figure 53 Drawing No. 3 Rearguard Action $\quad 76$

$\begin{array}{ll}\text { Figure } 54 \text { Drawing No. } 4 \text { Interior Exposure } & 78\end{array}$

$\begin{array}{lr}\text { Figure } 55 \text { Drawing No. } 5 \text { The Baron } & 79\end{array}$

$\begin{array}{ll}\text { Figure } 56 \text { Drawing No. } 5 \text { Surrounding Graveyard } & 81\end{array}$

Figure 57 Drawing No. 6 The Catotelm $\quad 83$

Figure 58 Drawing No. 7 Ruination $\quad 85$

$\begin{array}{ll}\text { Figure } 59 \text { The Broomway } & 89\end{array}$ 
Glossary of Enchantment

Acrotelm (V.16) - boundary of living plants and organic matter in the top $50 \mathrm{~cm}$ of the ground

Bealach [gaelic](BYALuch) - pass, route

Beinn [gaelic](Bayn) - mountair

Blashy (V.13) - Rainy, wet, gusty. Gen.Sc.

Catotelm (V.17) - lies beneath the water table in a peat / moor land. Stores / preserves the decayed organic matter. 'Cata' word form element meaning 'down, downward' and also 'through'.

Cèilidh (V.3) - a social event that relayed news, information and lore that was central to the identity of the village or town performed by the village bard. A community Gathering (V3)

Croc [gaelic](KROCHK) - hill

Croft - a small rented farm, especially one in Scotland, comprising a plot of arable land attached to a house and with a right of pasturage held in common with other such farms.

Coire (V.1) [gaelic] - corrie, a steep-sided hollow at the head of a valley or on a mountainside; a cirque. (V.2)

Copresence - occurrence of two or more things together in the same place and time.

Creag [gaelic](KRAYK) - crag, rock

Devalorize - to reduce something, or to de-valour something. To take away the value of something.

Druim [gaelic](DROOim) - ridge

Endurance (V.8) - to remain, to last, to endure.

Entangle (V.7) - to be twisted together, caught in something, entwined. 
Estate: (V.11) an extensive area of land in the country, usually with a large house, owned by one person, family, or organization

Gleann [gaelic](GLEH-own) = glen, valley

Goselet (V.15) - n. A soaking, drenching, downpour (of rain)

Hoar Frost = also hoarfrost, radiation frost, or pruina, refers to white ice crystals deposited on the ground or loosely attached to exposed objects, such as wires or leaves

Mercurial - something that is subject to a sudden or unpredictable shift

Precision (V.5) - not as an act of probing for answers, for newness or novelty, but as a form of watching and waiting

Provisional $=$ arranged or existing for the present, possibly to be changed later

Revere (verb) - to feel deep respect or admiration

Rionnach Maoim (V4) - shadows cast on the moorlands by clouds moving across the sky on a bright and windy day

Ruination - the operation or fact of ruining someone or something or of being ruined

Shift - a slight change in position, direction, or tendency.

Sithean, Sidhean [gaelic](SHEEhun) = knoll (often associated with fairies)

Smirr - A Scottish word to describe a fine, drifting rain or drizzle. A smirr is so light it seems like a mist or smoke.

Spindrift (V.14) - sea spray whipped up by gusts of wind and driven across the tops of the waves

Sron [gaelic](STRON) - nose, edge of mountain ridge

Stob [gaelic](STOP) - peak, summit, something sticking up like a post

Tartanry (V.11) -representations of traditional Scottish culture perceived to be stereotyped or kitsch, particularly those emphasised first by the emergent Scottish tourist industry in the 18th and 19th centuries, and later by the American film industry.

thick and thin - under all circumstances, no matter how difficult. Through thicket and thin wood - literal description of a determined progress.

Tracking (V.1) - etymology path : to learn ('to acquire knowledge') - leornian (Old English, 'to get to knowledge, to be cultivated') - liznogan (Proto Germanic, ' to follow or to find a track') - leis (Proto-Indo-European prefix, 'to follow a track') to track

Viscous (V.6) - internal friction - being in the thick of something, the sticky consistency between solid and liquid,

Will-o'-the-wisp (V.18) = Attributed to a flame-like phosphorescence caused by gases from decaying plants in marshy areas - people believed it to be carried by a sprite trying to lead them astray onto the moors - its Latin translation, ignis fatuus, means "foolish fire." Eventually, the name will-o'-the-wisp was extended to any impractical or unattainable goal. 
chapter i

The Context

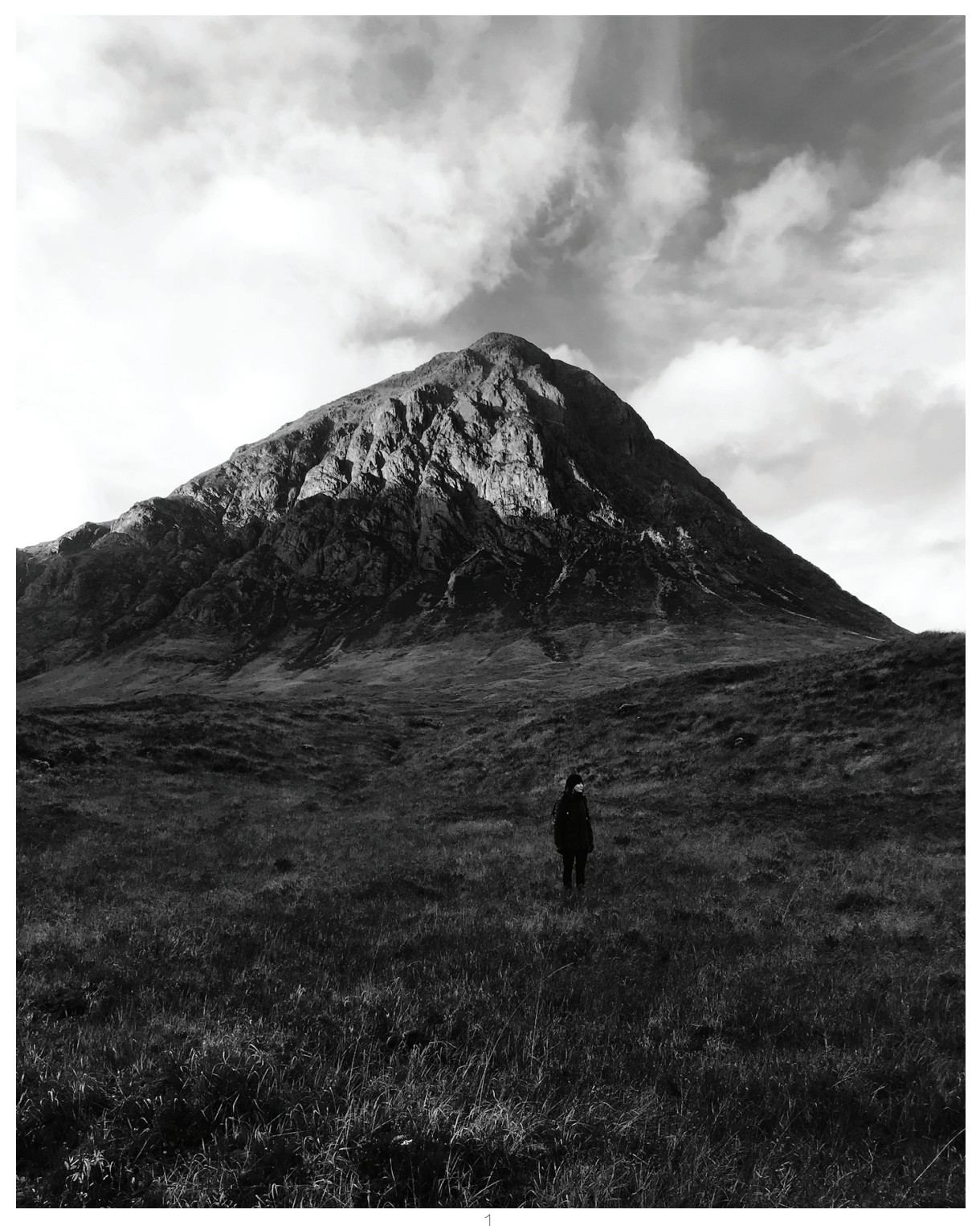

Figure 1

Buachaille Etive Mòr (The

Heardsman), Rannoch

Moor, 2020 


\section{I.I The Path / Slighe}

he Scottish Highlands remain, to this day, a place of
enchantment and wilderness rich in history and littered with
ancient castles and old estates. A "natural playground which begs to be explored..." extolls the Visit Scotland web page, conjuring a sense of idyllic scenery and vast, remote landscapes, ripe for the traveler and visitor. Reality, is of course, much different, stretching beyond touristic accolades. This landscape has a dark and complex history that is, more often than not, unacknowledged. Centuries of conflict in the British Empire delineate these lands and the wild 'playground' was once the site of mass displacement because of agricultural "improvement" and colonial control. Cambridge scholar Robert Macfarlane reflects on such landscapes on a journey to the Hebrides in his book Wild Places. He remarks "The pasts of these places complicate and darken their present wildness; caution against romanticism and blitheness. To be in such landscapes is to be caught in a doublebind: how is it possible to live them in the present, but also acknowledge their troubled histories?" This question set the pathway for this thesis as a way to reflect on how we communicate in our designed world/design worlds.

The paths and shapes of this thesis is tethered to the work of Robert 
Robert Louis Stevenson, Arthur Conan Doyle and Neil Gaiman.

Robert Macfarlane's pluralist vocabulary and verbal imagery track geological time, literature and myth to illuminate the relationship humans have with their landscapes and with the ground. His methodology stresses the importance of indexing, tracking and layering as a process to reconsider the relationship between space and ground. Both fictional and nonfictional sources inform the vibrant narratives of Macfarlanes work, an endeavor this thesis employs through its trajectory.

Nan Shepherd's book The Living Mountain eloquently captures the subtle details of the Cairngorm mountains in Scotland. Her descriptions helped my own understandings of landscape atmosphere. Since arriving in Scotland in October last year, my attention is continuously drawn to the way the light falls upon a room, streetscape, or a coire. She writes, "Light in Scotland has a quality I have not met elsewhere. It is luminous without being fierce, penetrating to immense distances with an effortless intensity." Her words reveal a dedication to the qualitative elements of landscape and place, and have inspired each stage of the research.

Rachel Hewitt's text Map of a Nation: The Biography of the Ordinance Survey details transitions of power and influence through land surveying and measuring strategies developed by the British Empire in the eighteenth and nineteenth centuries. Hewitt's work explores natural frontiers, nationhood and identity as they unfold with the complex history of mapping in the United Kingdom. Her writing emphasizes the agency and act of documentation; and of the immense responsibilities of pursuing and archiving knowledge through research.

Robert Louis Stevenson's Kidnapped, Sir Arthur Conan Doyle's Sherlock Holmes and the Hound of the Baskervilles and Neil Gaiman's The Graveyard Book were literary precedents, inspirations and catalysts for the thesis. These storytellers were an additional pathway and literary landscape for the thesis - the Scottish moor and its in-between spaces feature prominently in the works noted above. 


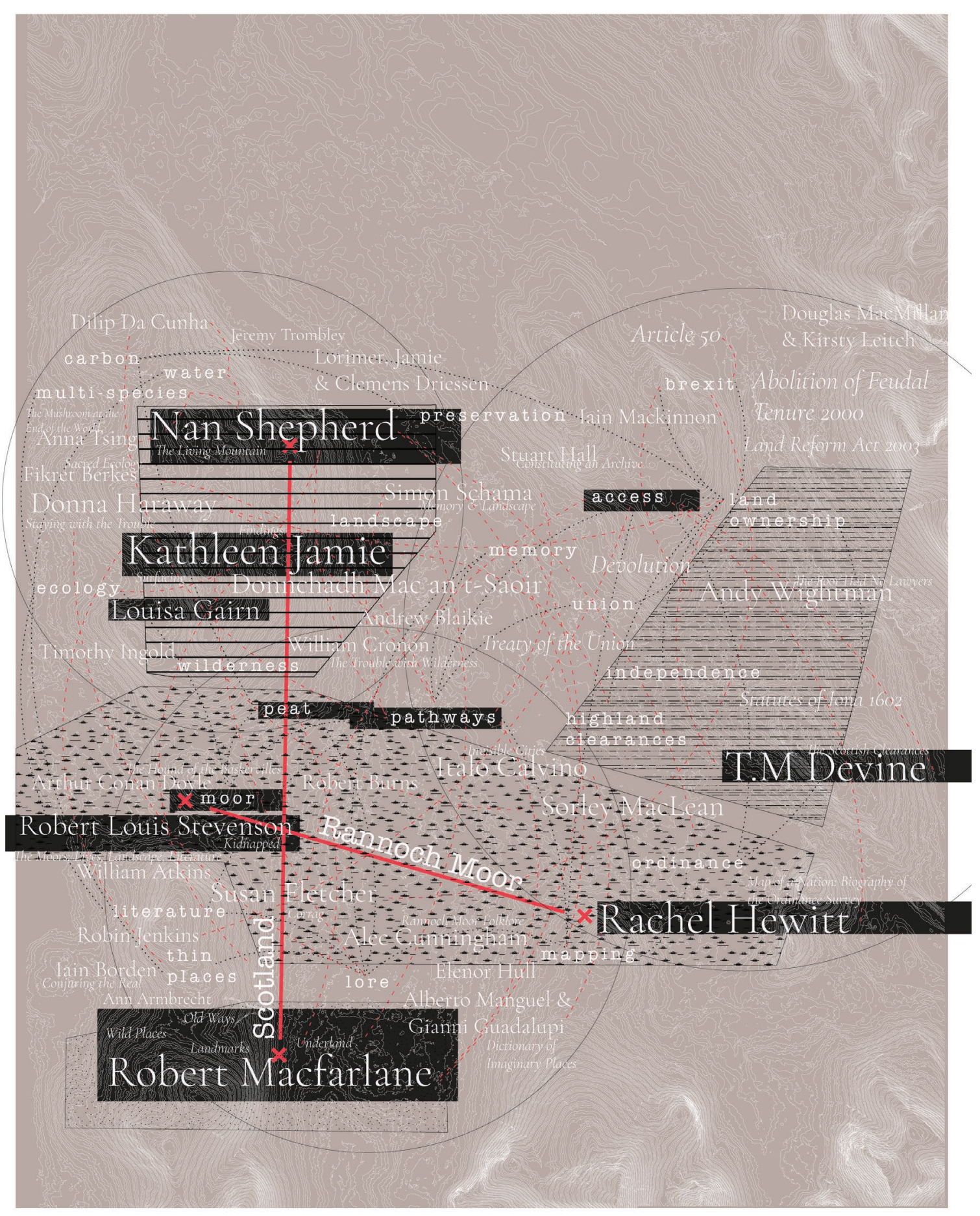


Gaelic language and storytelling has long been an important cultural tool for the historical populations in the Highlands. A central feature in everyday life, the oral traditions of these communities attempted to capture, contain and hold memory and culture and was used both as a form of education and record ${ }^{4}$. The figure of the bard was a central role that combined storyteller, historian, genealogist and composer. The bard would reflect on the world through performance called a ceilidh, a social event that relayed news, information and lore that was central to the identity of the village or town. This process was responsible for maintaining the local culture and keeping record of its history5.

In the seventeenth century this practice was outlawed by the British crown. Under the eighth clause of the Statutes of Iona the Gaelic tradition was to be suppressed in favour of the English language and education in the Lowlands of Scotland'. Today approximately I.I\% of the population speaks Scottish Gaelic?. The use of language and education were tools to gain control and exert dominion over the Highlands. As such, attention to documentation methods and sources are integral to this thesis, which draws on policy documentation, storytelling, myths, methods of linguistic mapping and data analysis throughout.

Surviving Celtic cultural traditions provide richly detailed and evocative, poetic descriptions of the landscapes and atmospheres. Such words are invaluable in piecing together an understanding of the Highland landscape. Gaelic poet Donnchadh Mac an t-Saoir's (anglicised Duncan Ban Macintyre) famous poem of Beinn Dorian offers a rich depiction of the flora and fauna of the site.

4 Grant, "'And in Every

Hamlet a Poet': Gaelic Oral

The hind's in the deer-forest

Where she ought to be,

Where she'll find sweet grass

Pure in the blade,

Heath-rush and deer-grass,

Herbs full of substance. ...
Tradition and Postmedieval

Archaeology in Scotland,"

30-31.

5 Grant, 31-32.

6 Goodare, "The Statutes of

Iona in Context," 53.

7 "Scottish Government

Gaelic Language Plan

2016-2021." 
Were primrose, St John's Wort

And tormenti1 flowers

The delicate orchids

Forked, Spiky and Smooth,

And meadows where it grows

In great clusters ${ }^{8}$

Macintyre describes things that are "Connected in movements / With separate purpose ... / There is an order /In their assembly..." He reveals a profound recognition of the interconnectedness of a landscape's ecologies. This holds important implications for the future of Scottish land and local environments, their historical relationships and speculative futures. The Gaelic language lends itself to detailed nature writing as it provides a comprehensive index of vocabulary to describe the specificity of a landscape. Conditions such as, "shadows cast on the moorlands by clouds moving across the sky on a bright and windy day," ${ }^{\text {זо }}$ are called rionnach maoim (Figure 3).

The decline of Gaelic literacy transformed the relationship people have with the ground, and moorlands in particular: "the keen sense of conservation that went with it has atrophied, as has the language which accompanied that sense." Macfarlane remarks here on the profound relationship between language, story, place and space. The act of storytelling as a cultural record, wayfinding method and place maker sits
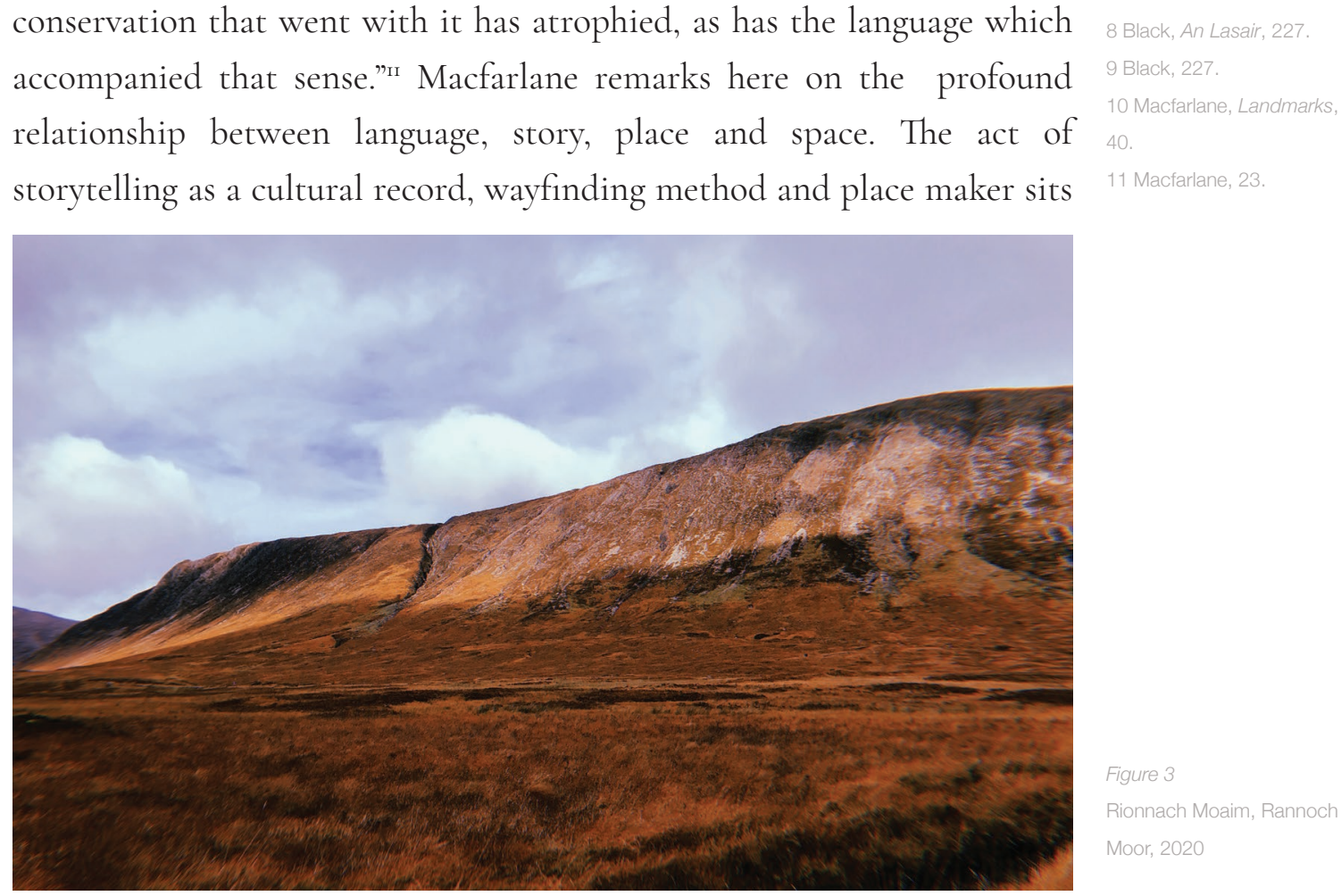
at the core of Highland histories, and as such, fictional narratives, lore and nature writing inform the architectural narrative of this thesis. The thesis inhabits a space between myth and reality, overlapping the supernatural and the real. It is inspired by Macfarlane's journey to the Onkalo nuclear waste site in Finland where anthropologists, historians, geologists, artist, architects, linguists and biologists gathered to design a warning system for future accidental visitors to alert them to the dangerous world buried deep in the ground. An 'active communication system' was proposed by linguist Thomas Sebeok, a system that would "relay the nature of the site using story, folklore and myth."12

Story provides an exploration into the deeper, slower (not just as a process of time), viscous, and enduring layers of architectural processes. Stories delve deeper into the rich and complex details of the narrative process. They are slower as an act of watching and waiting with precision; in opposition to the fast paced churn of superficial 'realistic' renderings. It is the ability to reflect quietly, staring deeply into the mirror rather than loudly and forcefully recreating the mirror. Stories can be viscous - as a state in which discourse can become entangled, twisted and turned in and over itself to explore different frictions, meanings, perceptions - think of Neo touching the mirror in the Matrix; is it the mirror that changes or his perception of what the mirror is. Their endurance lies in the ability to outlast the ego of a single name or noun; folklore, stories, myths, and fairy tales can be timeless. Novelist Angela Carter reflects on the idea of endurance within the realm of fairy tales: "Ours is a highly individualized culture, with a great faith in the work of art [architecture] as a unique oneoff, and the artist [architect] as an original, a godlike and inspired creator of unique one-offs. But fairy tales are not like that, nor are their makers. Who first invented meatballs? In what country? Is there a definitive recipe for potato soup? Think in terms of the domestic arts. This is how I make potato soup."'3 Carter acknowledges the deeper, quieter, slower, enduring beauty that can be employed by understanding the different rules of stories; shifting into tales that are neither fictional nor non-fictional, but sit in-between as simply story. She identifies the contact zones between the real and the imagined using the fluid boundaries of the story as a way

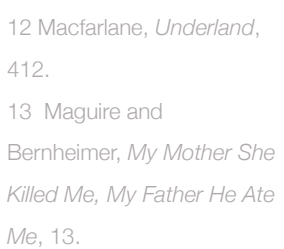

12 Macfarlane, Underland

13 Maguire and

Bernheimer, My Mother She Me, 13. 
to think through creative process. The story space devalorizes the single author, the individual ego, the 'godlike and inspired creator', an all too familiar archetype in the architectural discipline. This idea translates into the profession world through thoughtful design decisions; Tatiana Bilbao decided the use of computer rendered images would no longer have a place in her studio, opting instead to promote a collage based representation strategy. Bilbao believes this process "accepts all of [the] personalities, diversities and complexities that are not only my ideas...I want my architecture to be a platform for anyone to create their own way of living." ${ }^{\prime 4}$ Bilbao uses collage to work through a collaborative creative process, whereby the representation plays by the rules of the story; inclusive of, and open to other ways of seeing or thinking. Like a story, the collages create contact points between the real and the imagined, free from the tethered reality or perspective that renderings impose.

Stories delve into the thick and thin of it; opening passageways to alternative ways of understanding, diving into inquiries of language and literature, prompting operational cues, tools, and figures that help form the architectural narrative of space. Operations can be defined as words of description, action, state, things, or ideas that suggest ideas of spatiality, place, movement, position, adjacency, and so on, as they apply to a site. To think of an unsettled ground, for instance, can indicate the physicality of unsure footing or a metaphorical ground space of policy and management; a shifting landscape both literally and figuratively. It embodies material properties as well as atmospheric ones. Tools are the architectural, landscape, programmatic, and atmospheric instruments or agents that connect the figure to the operation; a door, for example, is a tool that allows one (the figure) to cross a threshold or boundary (the operation). The tools utilize prompts from Theo Deutinger's Handbook of Tyranny as a form of method from which to expand on and employ a more 'meta' definition of the term; what is a political tool? Tools of manipulation? Etc.. Finally, the Figures are characters, dramatis personae, or key actors in the research narrative. They are the lord and lady, the farmer, the politician, the wolf, the buried, and so on, who make up the species and creatures of the story. 
The pathway of this thesis began with an intensive site study; archiving and indexing through mapping, site visits, and documentation, diagrams and drawings to try and take in the fullness of Rannoch Moor and of the larger Scottish context. It explores ideas of connection and networks, memory, history, place and climate, tracking the investigations to issues of ownership, infrastructure, territory and access. This produced models of mini bogs and a thickening of the tangible with the other layers of the site - its literary and experiential histories, its real-life politics, and its multiverse of actors and agents (the dramatis personae). These paths go on to navigate how the landscape might engage spatially through the architectural and material realities of the site. A floating railway, the Estate/ Manor House, foundations and pathways; how do they engage with the surface, depths, and inhabitations of the moor? Both literally and figuratively? How do they shore, retain, balance, or hold back the earth? How do they walk on unstable ground? These curiosities led to a series of spatial collages (outlined in Chapter V) which unearth a process of meaning making and meaning revealing, informing the ethnography of my own understanding of the discipline. They become prompts for narrative and storytelling as a way to think about design and future histories, which ultimately led to a series of curious fables (Chapter VI) - speculative fiction about Rannoch Moor which is currently being developed as a series of stories and associated scenes that fold in, reflect upon, take hold, and play up the rich, magical, mysterious space on the moor.

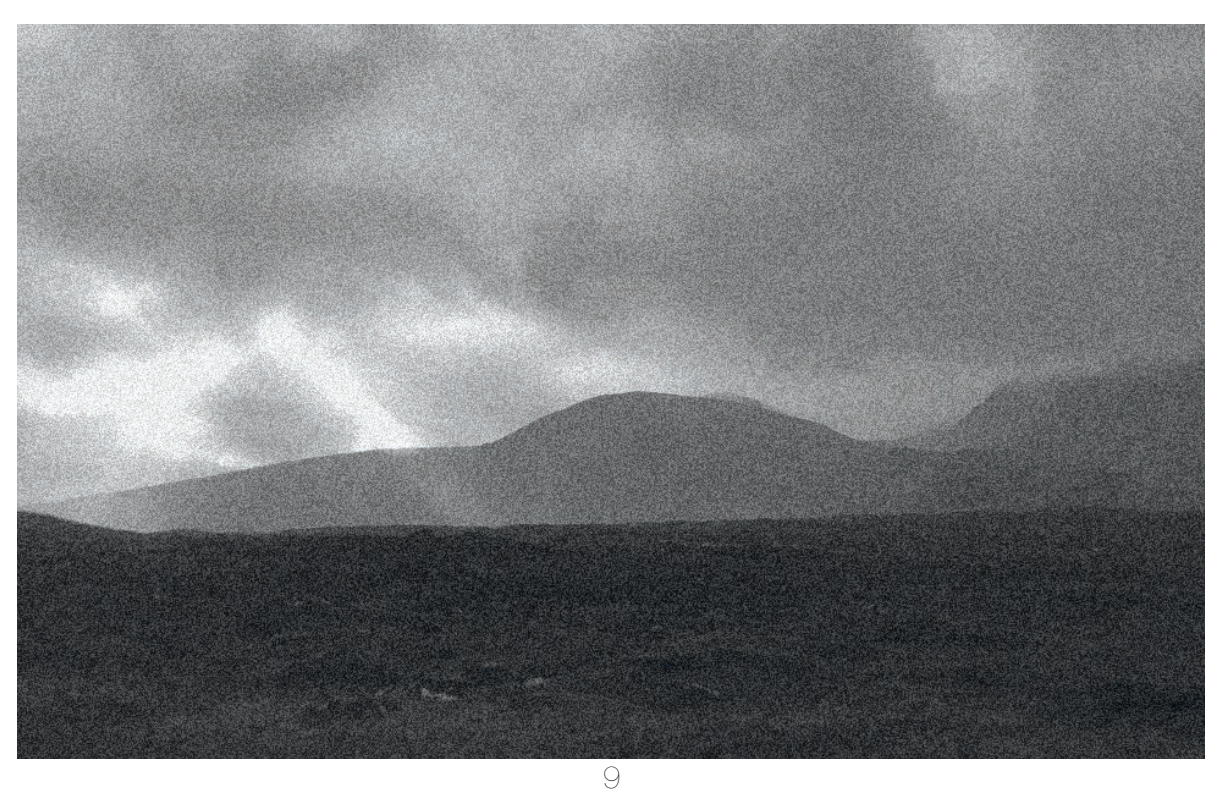




$$
\text { chapter i }
$$

Scotland

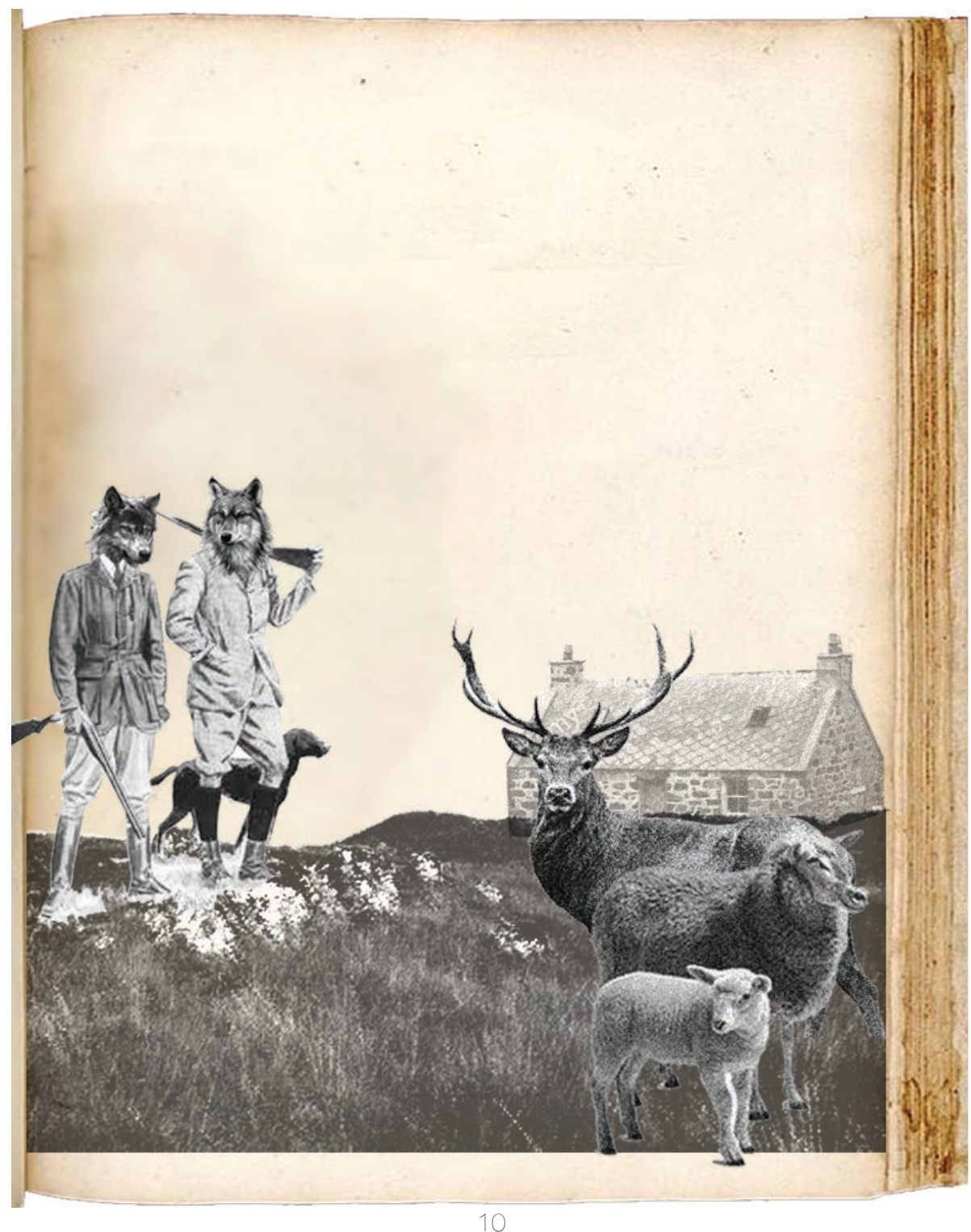




\title{
II.I The History / Eachdraidh
}

\begin{abstract}
ontrary to tourist and pop culture depictions of the Highlands as an 'untouched' landscape, these lands retain subtle indications of past occupation. During the $18^{\text {th }}$ century the British government created policies of clearing and displacing entire villages in the Scottish Highlands for agricultural "improvement." Forced removals of people resulted in a loss of culture and language. The Clearances, as they were known, and agricultural changes to the landscape caused significant emigration to Canada and New Zealand, depleting local populations but creating new terrains for sheep farms and other more profitable industries that fuelled the British Empire ${ }^{15}$. These now vacant and remote terrains have been romanticized and as wild and ancient landscapes - and incorrectly as untouched wilderness. Humans were very much present in the remote areas of the Highlands, and the crumbling structures of their pasts are still evident. Sorley MacLean describes it as follows:
\end{abstract} 0.2 0.3

"If it doesn't, I'll go to Hallaig, To the sabbath of the dead,

Down to where each departed Generation has gathered. Hallaig is where they survive, All the MacLeans and MacLeads Who were there in the time of mac Gille Chaluim:

The dead have been seen alive" 
The sense of loss is evident as the poet visits Hallaig, his family village. Scottish Historian Thomas Devine examines the role the Clearances have played in Scottish history in relation to shifting attitudes in land management. He describes the decline of the clan system in the early seventeenth century as having unravelled the social fabric of the Highlands. Under the reign of James VI, imperial law was enforced through strategic policies and land expropriation. ${ }^{17}$ A key moment in this history is the collapse of the Jacobite uprising at the Battle of Culloden in I745; commonly referred to as 'the 45.' Highland clans supported the Stuart monarchy who had been removed from the throne in i688. Charles Edward Stuart was a Catholic and a Scot, favoured over the Protestant Dutchman that sat on the throne of England. The last battle fought on British soil, it marks a significant moment in the history between Scotland and England. After losing the battle, the British army sought to subdue the Highland territory, determined to crush any future rebellion. Land holdings in the Highlands were appropriated once again, estates and farms seized under British authority and the first set of Clearances began ${ }^{18}$. The delineation of the landscape during the eighteenth and nineteenth century following 'the 45' still exists today, reflected in the vast estates that remain in the Highlands. The Clearances remain fresh in Scottish politics as land reform is an ongoing topic of discussion.

The I8th century also saw the formation of the Ordinance Survey (Fig. 6). A direct response to the Jacobite rising, it focused on strategies of mapping and infrastructure development as a policy of governance and control. Rachel Hewitt notes:

"Strategies to 'pacify' the Highlands after the Jacobite Rebellion in 1745 - disarming of the clans, the establishment of soldiers to police the region, the building of better roads and the confiscation of Jacobite estates for the purposes of civilizing, and promoting the happiness of the Inhabitants upon the said Estate...by promoting amongst them the Protestant Religion, good government, good Husbandry, Industry and Manufacturers. Many considered that the Highland landscape was responsible for its inhabitants rebellions behaviour. Mountains and lochs formed natural

17 Devine, The Scottish Clearances, 37-40. 18 Hewitt, Map of a Nation, 20-27. 
barriers between clans, fostering a profound sense of community and dividing Highlanders from Lowland influence. One man felt that Highland chiefs were mirrors of their surroundings in more metaphorical ways too: both were useless, obstructive and terrifying. "Such Noble-men as these are like Barren Mountains, that bear neither Plants nor Grass for Publick Use. They touch the Skie, but are unprofitable to the Earth."'?

Connections between people and place are used to identify the nature of a frontier; one that the British Empire sought to tame and control as they ventured farther north into the Highlands. After 'the 45 ' the British military realized they lacked information on Highland geography and terrain, making it harder to track down and pacify rebellious clans. Mapping space and infrastructure became methods of control, used to take command of a landscape and render it as an extractive terrain.

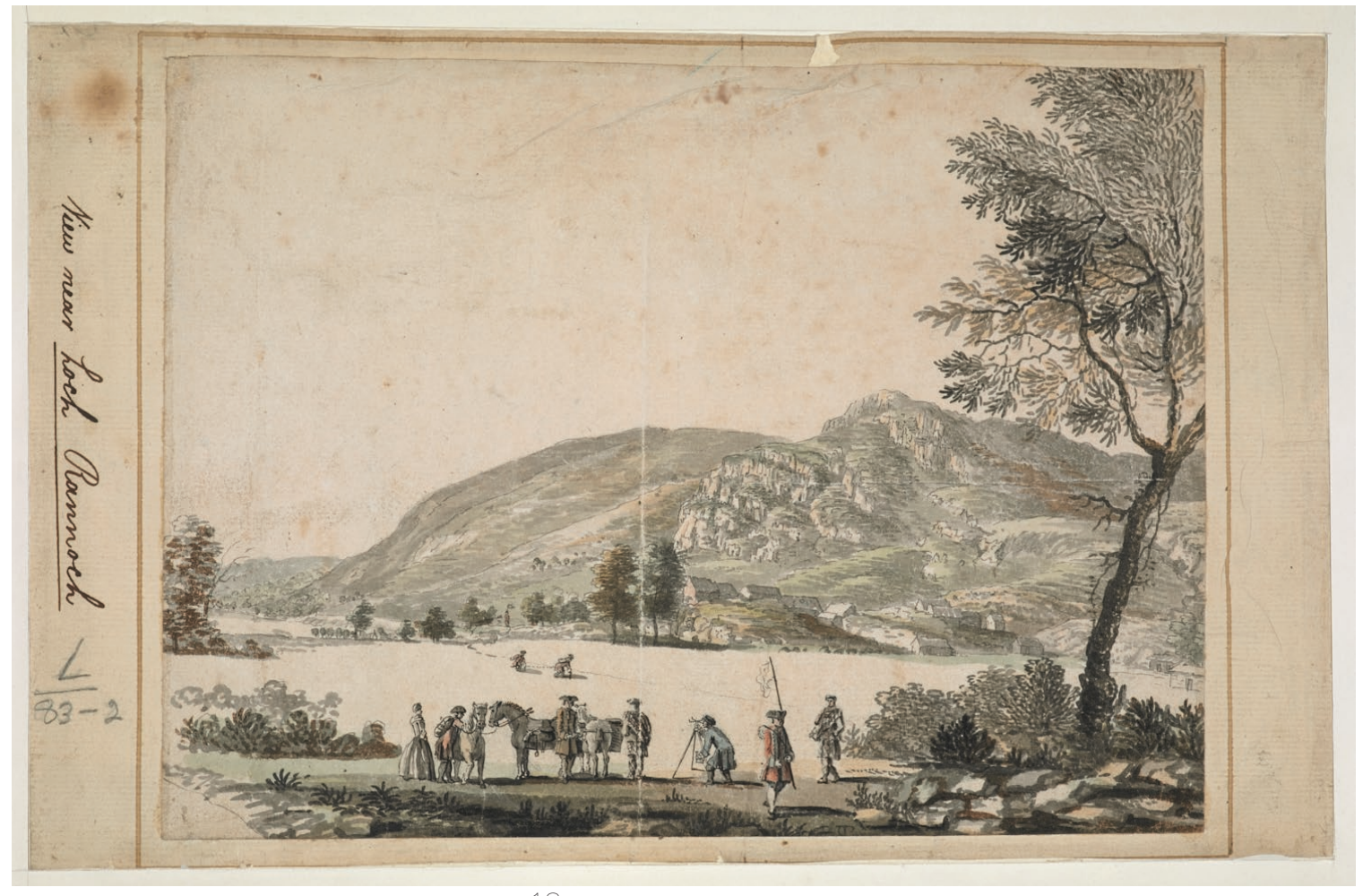




\section{II.II The Wild}

Scotland has some of the inequitable land ownership practices in the western world, with 1235 owners owning $70 \%$ of the land: $0.0002 \%$ of the country's 5.454 million people own $7 /$ Ioths of it land. Among these owners are Anders Holch Povlsen, a Dutch retail magnate, Kirk Kristiansen, the CEO of LEGO, the Duke of Buccleuch, and Donald Trump, effectively creating a concentration of land ownership in a small fraction of wealthy elites $^{20}$. Some of these holdings date back to the Clearances when it was common to grant British gentry with the expropriated properties of the Highland clans. It was not until 2000 that Scotland abolished feudalism with the Abolition of Feudal Tenure Act ${ }^{21}$. There has been since a rapid development in the advocacy for land reform. The Scottish Land Reform Review Group was formed by the Scottish government to conduct research into land reform in the hopes of "enabl[ing] more people in rural and urban Scotland to have a stake in the ownership, governance, management and use of land, which will lead to a greater diversity of land ownership, and ownership types, in Scotland."22

The report was finished in 20I4, and detailed suggestions for the future of land practices in Scotland. It called for transparency in title holdings and purchaser protection of public and common lands and denounced the out-of-date policies that protected large estate holdings ${ }^{23}$. Concentrations of land and wealth are unsustainable as they do not provide a diversity of holding types, and are inequitable in terms of holding significant power within the country. Sporting estates cover approximately 2.I million hectares, more than fifty percent of all privately owned land in the Highlands with the average estate owning 5000-80oo hectares ${ }^{24}$. Ailsa Raeburn, chair of Community Land Scotland, notes:

"We know there are lots of concerns locally about the impact of some large landowners and the power they feel they can exercise over local people and local democratic decisions. This is Scotland in the 2ist century, a Scotland with a very exciting future for its people and land - not a Scotland

\footnotetext{
V. 11

20 Wightman, The Poor Had No Lawyers, 340-55. 21 "Abolition of Feudal Tenure Etc. (Scotland) Act 2000."

22 "The Land of Scotland and the Common Good: Report - Gov.Scot." 23 "The Land of Scotland and the Common Good: Report - Gov.Scot." 24 Wightman, The Poor Had No Lawyers, 342.
} 
rooted in the igth century where a very small number of people held huge power over the land and its people. Diversifying land ownership and spreading the benefits of who owns the land and natural assets is critical to achieving this fairer Scotland." ${ }^{25}$

These concerns reflect the historical narrative that has defined the Highland landscape and raises questions regarding inequitable access to space which has resulted in diminishes and decaying northern communities exacerbating the divide between people and land.

The hunting estate marks the next phase of Highland land use after the Jacobite fall in I745. As the development of roads and boundary markers were established through military surveying efforts, lodges and estates were built to host the landed gentry. The establishment of this property type has significant cultural implications, giving rise to the to the $\mathrm{I} 8^{\text {th }}$ and $19^{\text {th }}$ century development of tartanry. The sporting estate became a symbol of the hunting lifestyle in British high society, a theatrical display of pomp and circumstance ${ }^{26}$ (Fig. 7). Many of these estates sit on vast swaths of land, their boundaries overlapping with conservation designations such as Sites of Specific Scientific Interest or Areas of Outstanding Natural Beauty. The delineations of these areas are somewhat arbitrary in that the ecosystems they seek to protect, study, or hunt, are not bound to these edges.
25 Davidson, "Magnus

Davidson Becomes

Youngest Member of

Community Land Scotland Board."

26 Wightman, The Poor Had No Lawyers, 347.

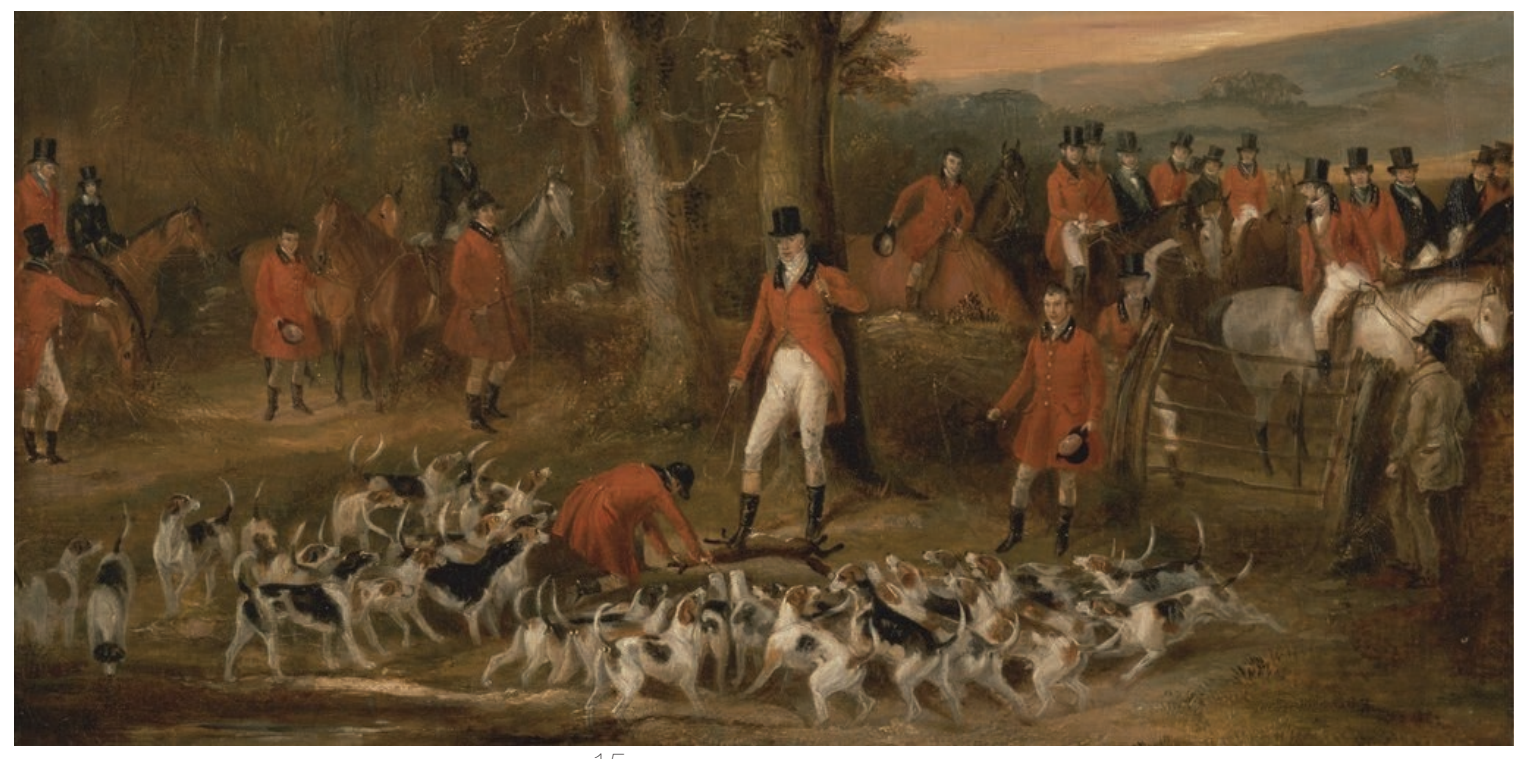

Figure 7

Below: Francis Calcraft Turner, active 1782-1846, British. 1842. The Berkeley Hunt, 1842: The Death. Painting, sporting art. Place: Yale Center for British Art, Paul Mellon Collection. 
Due to the concentration in private land, challenging questions arise regarding diversification of the landscape, public infrastructure, pathways, and decisions on best practices for land management. Wealthy landowners can make unilateral decision about their estates, regardless of related cultural, social, economic or ecological impacts. Paul Lister sits in the middle of these types of debates. He is the owner of the 23,000 acre Alladale Estate, located in Sutherland, in the north of the Highlands. Unlike the majority he proposes something different: rewilding. He argues that land should be returned to the way it was 3 oo or so years ago, citing the old Caledonian forest and wolf ecologies that have long been absent from the land, believing that visitors wish to see "original" flora and fauna ${ }^{27}$. Although Lister professes 'sustainability' and a 'nature first,' ethos, his decisions could have far reaching and detrimental effects. Crofting communities that rely on communal land for agricultural practices would risk losing their flocks should wolves be reintroduced to the area. Once abundant, the last recorded wolf on Rannoch Moor was documented at the beginning of the I 8 th century, ${ }^{28}$ symbolizing today the monopoly of power as proposals of rewilding fail to consider the health of local communities that now depend on the land. This evokes old dynamics between 'lord' and 'tenant' and policies of land clearance and "improvement." Landowners, in 27 Simpson, The Cull: Scotland's Deer Dilemna. 28 Cunningham, A History of Rannoch Moor. 29 Simpson, 28:30. 30 Berkes, Sacred Ecology, 9. a way, have become new the wolves.

Vivian Montgomery works the Croft of Clune and feels that this is the Highland Clearances all over again: rewilding will mean rapid treeplanting, displacing families and devastating, in turn, local communities. To her, "there is no wild land in Scotland." ${ }^{29}$ Rural communities risk losing their livelihood and local community due to the isolated nature of the model Lister proposes. Montgomery symbolizes the traditional models that have existed on the landscape for hundreds of years in which humans and local ecologies exist relationally based on understanding of natural balance. Fikret Berkes, an ecologist whose work investigates the interface of natural and social life, reflects on these systems; "[they] tend to have a large moral and ethical context; there is no separation between nature and culture. In many traditional cultures, nature is imbued with sacredness... characterised by embeddedness of knowledge in the local cultural milieu, bounded in time and space [emphasising] the importance of community."30 
An ecologist for Nature Scot, a government funded natural heritage organization in Scotland, Cathay Mayne expands on the politics and risks of rewilding,

"...[it] is based around people who have a lot of money, usually made elsewhere, involved in ecotourism. It takes away all forms of production, people living in the environment...most rural jobs would disappear. By taking away the capacity to keep producing here, and turning it into this wild landscape that we sell to tourists we are less sustainable. We would need to produce things elsewhere and bring it in." ${ }^{\text {I }}$

She targets the separation of society and nature, outlining the social and economic ramifications of creating such a binary division of the landscape. Other critics share similar views in that rewilding merely creates a wild theme park that increases the divide between humans and a viably sustainable land stewardship practice. Mayne points out that it creates issues around equity as well. Why should one place enjoy a wild state while others forfeit theirs in order to produce the things people consume? These issues of spatial equity are complex and are deeply rooted in time and place.

II.III The Vote

Land ownership and management practices provide a natural segue to Brexit. The historical narrative of property rights, clearances and land use has created a cultural, social and environmental divide between Scotland and England over the future of these landscapes. This thesis draws on the continuously unfolding circumstances and politics of Brexit to contextualize and understand divisions and political boundaries that inform notions of ground and space.

The first referendum for Scottish Independence (Fig. ro) was held in 2014 and just under half of the population voted to remain in the United Kingdom ${ }^{32}$. When the United Kingdom asked the four nations (Northern Ireland, Wales, Scotland and England) to vote on whether to remain in the European Union in 2016 (Fig. 9). 62\% of Scotland voted to stay within the EU, the highest percentage among the four nations ${ }^{33}$. Leaving the European Union was not a factor in the initial 2014 independence

31 Simpson, 32:12.

32 "Scottish Independence

Referendum - Results - BBC News."
33 "EU Referendum Results - BBC News." 
referendum, allowing questions of independence to reopen for further consideration after the Brexit vote. In the last few months it has been recorded that at least $54 \%$ of the Scottish population would be in favour of another independence referendum ${ }^{34}$. With the Scottish election looming in May 202I, the Scottish National Party led by Nicola Sturgeon leads with $56 \%$ constituent support, and will push for independent sovereignty, ${ }^{35}$. The Scottish government has been clear from 2016 that Brexit would not be in the best interest of the nation. A statement on the Scottish Government website states, "Scottish Ministers have consistently highlighted that the UK Government failed to engage meaningfully with the Scottish Government on Brexit since Article 50 was triggered in March 20I7, despite repeated efforts by the Scottish Government to find comprise options." ${ }^{\prime 6}$ 34 McDonnel, "Scottish Independence."

35 McDonnel. 36 "Brexit - Gov.Scot." The tension between Westminster and Holyrood is palpable as the future of the union (Fig. II) lies on unstable grounds.

\section{II.IV The Estate}

The archetypes of land structures bring architecture into the realm of political debate and sovereignty. The political future of the country suggests uncertainty, a shifting terrain, an unsettled ground. This ambiguity is a catalyst to help speculate on the future of Scotland. The Estate - as an architectural type - represents an out-of-date façade, an anachronistic colonial world that caters to a deeply rooted class system not always invested in the broader health, wellness or uplifting of local communities or landscapes. A lone structure in a vast landscape. The Manor or Estate house is metaphorically shored up in the moor landscape, propped up by ideas of sovereignty and empire; a romanticized idea of the hunting estate complete with pomp and circumstance and the conceptual foundation of maintaining ideas of grandeur and facadism. It represents a history of contentious policy that has governed Scotland within the terms of the union and encourages further speculation into the future of the Empire within Scotland's landscapes.

The Estate symbolize the inequitable land distribution mentioned previously and are intrinsically linked to ideas of ownership and access. In 2003 Scotland passed the Land Reform Act (Fig. 8) which opened up large 
swaths of land and water to public access, but also included the initial structure of community land purchase rights. The Act states :

"An Act of the Scottish Parliament to establish statutory public rights of access to land for recreational and other purposes, and to extend some of the provisions for that purpose to rights of way and other rights; to make provision under which bodies representing rural and crofting communities may buy the land with which those communities have a connection; and for connected purposes." ${ }^{37}$

The legislation identifies the tangled nature of ownership and access and sets up the first steps in dismantling the concentration of private Estate holders, with successful buyout cases stressing issues of absentee landlords, lack of investment, and historic injustice. However the legal navigation process remains complex and only a handful of communities have been successful in land bids. ${ }^{38}$

\section{7 "Land Reform (Scotland) Act 2003," 1 . \\ 38 Carrell, "Scottish \\ Village Buys Large Part of Langholm Moor from Duke of Buccleuch." 39 "Land Reform (Scotland) Act 2003," 1-2. Chapter 1 \\ Section 2 \& 3 40 "Land Reform (Scotland) Act 2003," 2. Chapter 2, Section 6, Subsection ii 41 MRS. ANN GLOAG v. PERTH AND KINROSS COUNCIL+THE RAMBLERS ASSOCIATION.}

The Act also enshrines the 'right to roam' in law. It allows "access rights to: (a) the right to be on land; and (b) the right to cross land...exercised (a) for recreational purposes; (b) for the purposes of carrying on a relevant educational activity; or (c) for the purposes of carrying on, commercially or for profit." 39 However the Act also has a provision that this access may not be granted if it there is "a building or other structure or works." ${ }^{\circ 0}$ This begs the question of whether or not this can be enforced on the vast estate holdings in the Scottish Highlands. In 2007 Ann Gloag took the Council of Perth and Kinross to court, requesting that her estate be off limits to pedestrians citing the need for increased privacy. ${ }^{4 \mathrm{I}}$ She won and her court case set a dangerous precedent for further estate owners to restrict access on their holdings. It further demonstrates the deep complexities between the Estate model and the ancient traditions and responsibilities of the commons. 

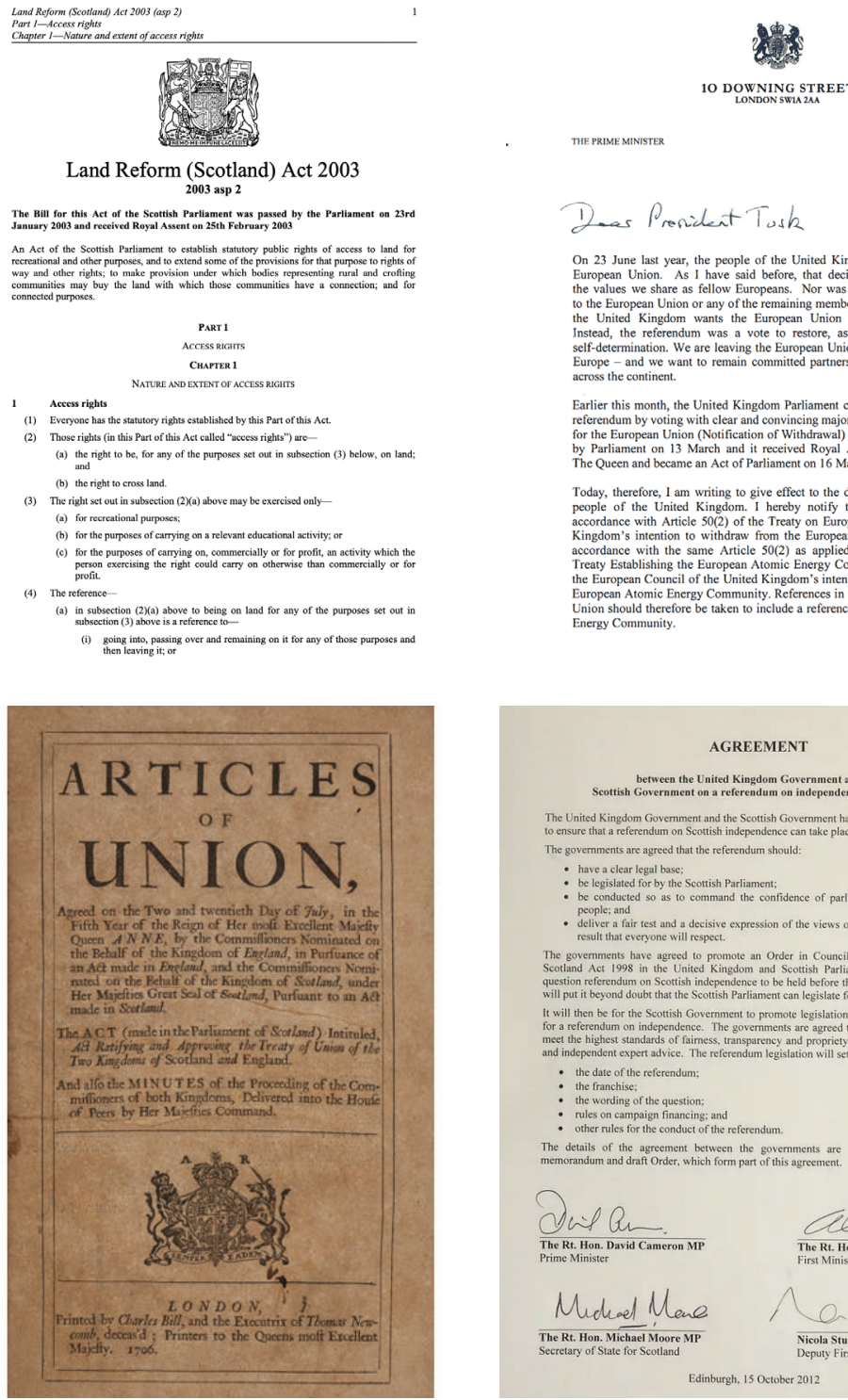

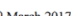

Dear Prenicunt Tosk

On 23 June last year, the people of the United Kingdom voted to leave the
European Union. As I have said before, that decision was no rejection of the values we share as fellow Europeans. Nor was it an attempt to do han the United Kingdom wants the European Union to succeed and prospen Instead, the referendum was a vote to restore, as we see it, our nationa Europe - and we want to remain committed partners and allies to our friends across the continent.

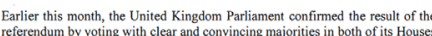
for the European Union (Notification of Withdrawal) Bill. The Bill was passed
by Parliament on 13 March and it received Royal Assent from Her Majesty Pet of Parliament on 16 March

Today, therefore, I am writing to give effect to the democratic decision of the people of the United Kingdom. I herbyy notify the European Council in
accordance with Article 50 (2) of the Treaty on European Union of the Unita Kingdom's intention to withdraw from the European Union. In addition, in he European Council of the United Kingdom's intention to withdraw from the European Atomic Energy Conm Energy Community.

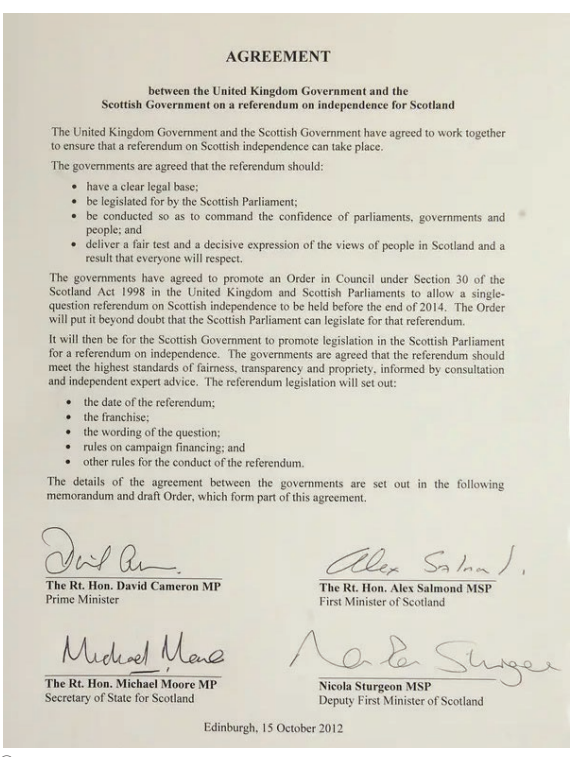

20
Figure 8-11

Policies of union, property, and access. From Top Left Clockwise: "Land Reform (Scotland) Act 2003." Digital Image. Scottish Parliament, 2003. Accessed 2020. https://www.legislation. gov.uk/

"Article 50 (Brexit) Triggering Document" Digital Image. United Kingdom Parliament, 2017. Accessed 2020. https://www.gov.uk/ government/publications/ prime-ministers-letter-todonald-tusk-triggeringarticle-50

"Scottish Referendum 2014 Document". Digital Image. Reuters. 2014. Accessed 2020. https://www.bbc. co.uk/news/uk-scotlandscotland-politics-19952630, "Articles of the Union 1709". Digital Image. 2015. Accessed 2020. https:// www.abdn.ac.uk/historic/ actsofunion/image3.php 
"...regional summer mean temperatures are projected to increase by between 0.9 $4.5^{\circ} \mathrm{C}$ by the zo5os compared to a 1961-1990 baseline. Regional winter precipitation totals are projected to change by between $-2 \%-+31 \%$ for the same scenario. Sea level is expected to increase by approximately $20-40 \mathrm{~cm}$ by 2090 compared to a 1990 baseline. Higher rates of sea level rise for the UK of up to 1.9 metres by 2100 have been estimated for a physically plausible high++ scenario based on in direct observations of past climate change events... sea levels are projected to continue to rise beyond 2100 even in lower emission scenarios and several meters of sea level rise within centuries is possible... Scotland has relatively lower temperatures and higher levels of precipitation than other regions of the UK. However, there is regional variation with the Western Highlands being exposed to relatively more wind, rain and snow than Eastern Scotland."27

Climate change projections indicate that Scotland will experience more precipitation and rising waters in the coming years. This is especially significant as Scotland's rivers and lochs contain 90\% of surface freshwater for the United Kingdom and host the highest points of the national watershed (Fig. I3). The relationship between the landscape and its water systems will becomes increasingly important as affected terrains will be forced to adapt to wetter, soggier conditions.

Dilip Da Cunha highlights the importance of recognizing the interrelated systems that exist between water and land, arguing against the delineation between the two. He observes the colonial relationship between humans and rivers, that at a point in time people identified the river, and in doing so allowed it to be seen and in doing so reifying the ludicrous assumption that that flora and fauna see the same thing we do. His profound recognition of the delicate ecosystems that engage with water as more than lines on a map reminds us that in order to design for water, we must design for wetness $^{43}$. Wetness is integral to the Scottish climate, a critical element of its future terrains. Not only in the ground, but as fog that appears as thick as clouds, of the harsh wet winds that blow the North Sea over the heather, or of the constant humidity that hangs in the air and dwells in your bones.

42 "Scotland Climate Change Evidence Report." 43 da Cunha, River Vs Rain Dilip Da Cunha. 
The wetness floods into the cultural identity of place in Scotland, working its way into fashion (wax jackets, sturdy wellies and a go-to fisherman sweater), art (see Figure 3I, 32), and language. Between Scottish Gaelic and Scots dialect, there are over one hundred words to describe rain. They are a wonderful range of words that capture the fantastical element of water well; blashy describes rain at its wettest, and most gusty; blashes against the window in a storm ${ }^{44}$. Spindrift envisions "sea spray whipped up by gusts of wind and driven across the tops of the waves." ${ }^{35}$ Or to get caught in a drenching, bone soaking, downpour is to be caught in a goselet. ${ }^{46}$ The list goes on as the words work their way through changes of direction, weight, speed and force. They reflect a culture that responds to changes of state through adaptation; the weather changes quickly and therefore so should the language, and so should the mind and the perception. The water permeates the language, seeping into the cultural identity of the nation and defining the local landscape

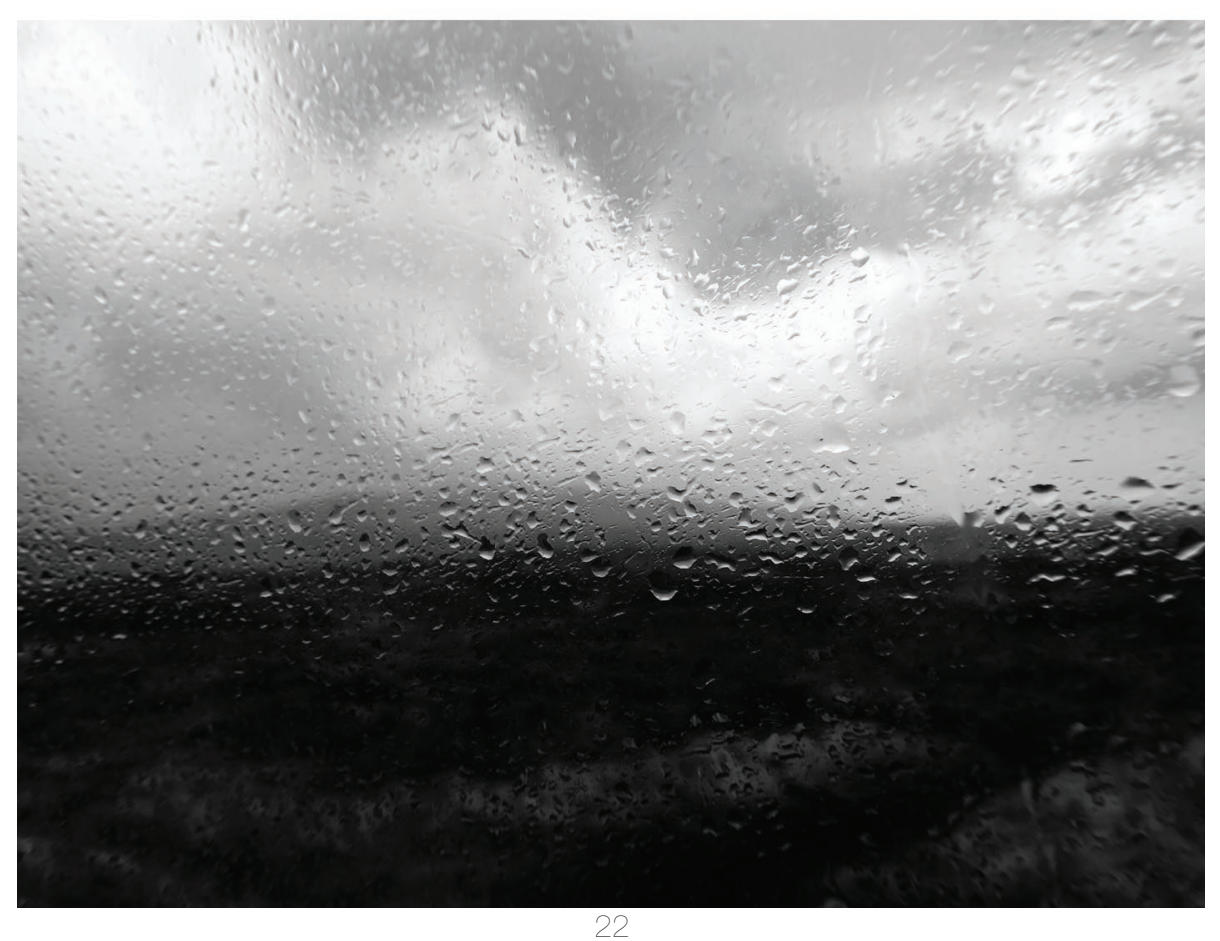




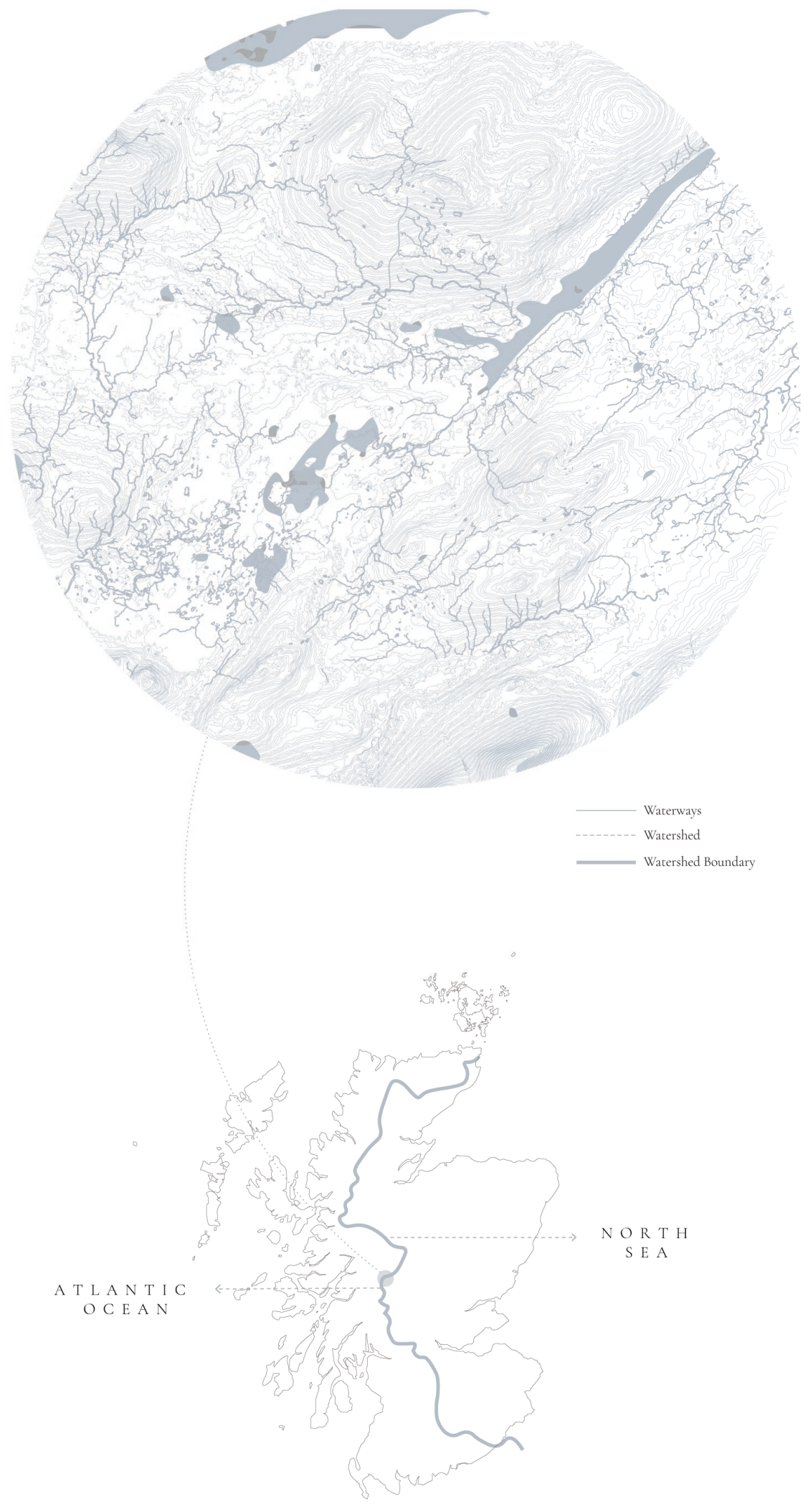

Figure 13

Waterway Mapping of Rannoch Moor and Scotland 
chapter ivi

The Moor

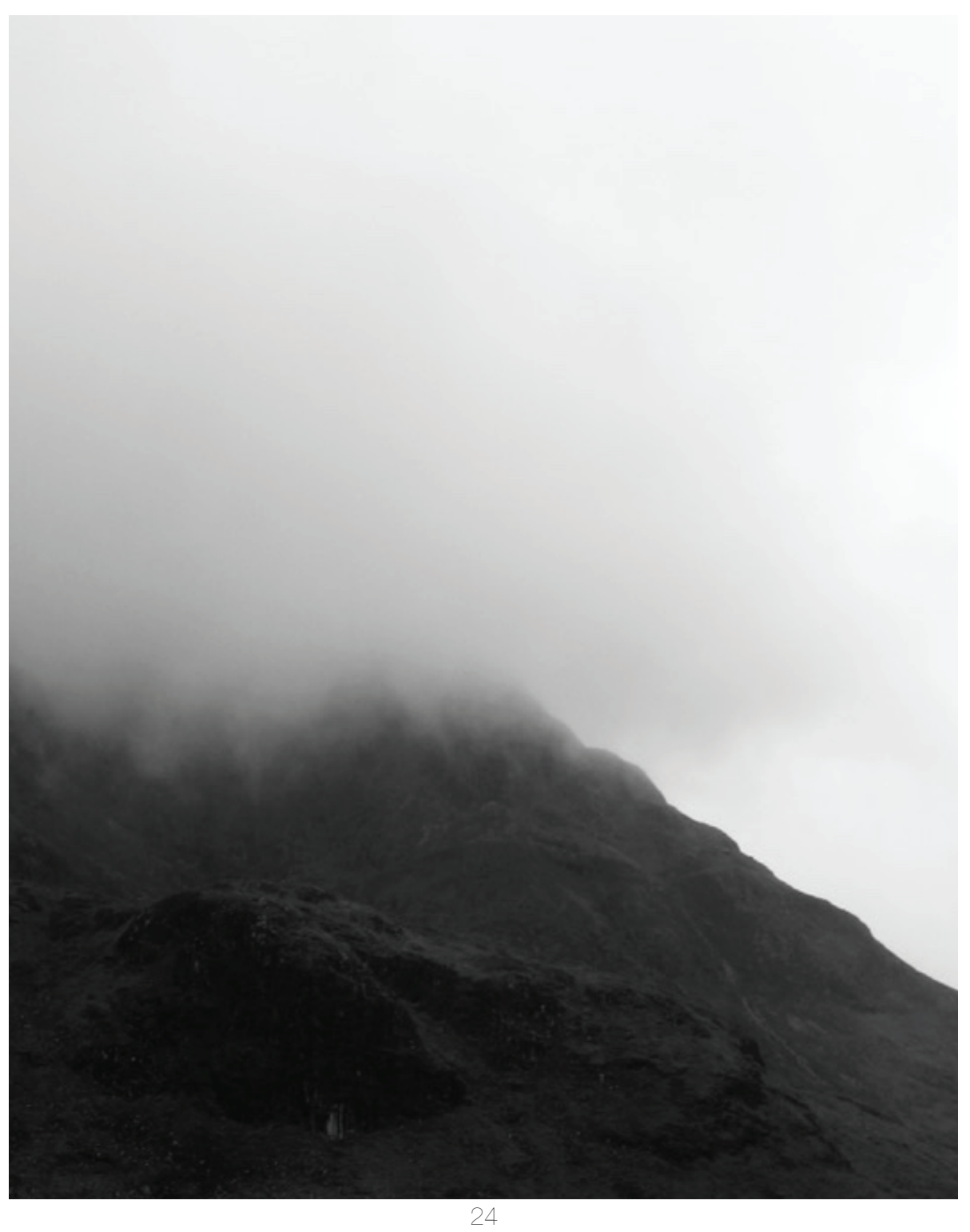




\section{III.I The Imagination}

$\mathrm{T}$

he moor is many things: it is peatland, bog, fen, , mire, swamp. It connotes denotes being 'bogged down' such as in a quagmire: soft boggy area of land that gives way underfoot or suggests an awkward, complex, hazardous terrain. To be mired is to be stuck, or be involved in a difficult situation. The moor is a place is a place that you can be sucked into, sunken down and through, enveloped. The moor is both literal and figurative, real and imagined, a place and a state of being.

Moors are the sites of eerie tales, cautionary legends, the supernatural, home to mythic beasts and predators werewolves, giant dogs, kidnappers. The moor features frequently in literature and pop culture as a site of the unknown; it welcomes and hosts spectral forces and tragic events. Sir Arthur Conan Doyle's Hounds of Baskerville introduces the reader to the land: "...in front of us rose the huge expanse of the moor, mottled with gnarled and craggy cairns and tors. A cold wind swept down from it and set us shivering." ${ }^{47}$ In Doyle's description, the moor is something fantastical and overbearing; something to be feared. We read from Willian Atkins, Nan Shepherd, Robert MacFarlane, Arthur Conan Doyle and John Milton:

It was a place of unreachable loneliness, the stage for sacrifice, exile and the outplay of grievance. It was a setting for love, and what came with love. It was
47 Doyle, The Hound of the Baskervilles, 108. 
a place of discarded symbols. It was wind strong enough to make a bull kneel. It was rainfall measured in the height of children. It was where you went to hide. ${ }^{48}$

'Knowledge does not dispel mystery', 'the more one learns of this intricate interplay of soil, altitude, weather, and the living tissues of plant and insect... the more the mystery deepens... ${ }^{4}$

...we began to learn the habits and the obligations of the moor, its resistance to straight lines of progress. As Murray knew, going on the moor is slow. To be measured in hours not miles. "“o

As you look at their gray stone huts against the scarred hill-sides you leave your own age behind you, and if you were to see a skin-clad, hairy man crawl out from the low door fitting a flint-tipped arrow on to the string of his bow, you would feel that his presence there was more natural than your own. ${ }^{\mathrm{r}}$

[As] a flame,

Which oft, they say, some evil

48 Atkins, The Moor. 49 Shepherd, The Living Mountain. 105. 50 Macfarlane, The Wild Places, 74 .

51 Doyle, The Hound of the Baskervilles, 137. 52 Milton, Paradise Lost. 9.631-642

Spirit attends,

Hovering and blazing with

delusive light,

Misleads the amazed night-wanderer

from his way

To bogs and mires, and oft

through pond or pool;

There swallowed up and lost,

from succour far. $5^{2}$

-9.63I-642 Paradise Lost

Phantom lights, unusual smells and unsure footing are common on the moor. Historical findings reveal sacrificial lands, ancient archives of butter and cautionary tales of wandering out into its wet, clouded expanse. It is an in-between space, mysterious in its physical composition, both earth, water, air, mist, cloud, rain,. The ground of the moor - peat - is neither alive or dead. The ground of the moor is $80 \%$ water but it is not a river, nor is it terra firma. The moors exist in the mind as an intermediate terrain. These landscapes are synonymous in the Highlands with the notion of "thin places"; places in which the distance between heaven and earth are lessened, perceived as closer due to the unearthliness of the terrain (Fig.I4). 
Moorland is peat. Historically, peat has been used as a source of fuel. It is rich in carbon and peat "bricks" are harvested (cut and pulled) from the ground and burned. It is extracted from the ground by clearing the top layer of heather and cut using spades that are also used to carved the peat into units. The bricks are left to dry before being used in the home, in kitchens, hearths and fire-places. Harvesting peat was a community process, digging and stacking volumes of peat for through the year ${ }^{53}$. Today it is seldomly used as a main source of fuel and is sparingly used as fertilizer or for the fire. It has a warm earthy smell and a dry heat when ignited.

Peat is formed when captured and store dead organic matter is saturated with water and sphagnum mosses. The waterlogged condition of the moor's ground is almost devoid of oxygen, yielding high acidic content that helps the ground to preserve organic matter. The acrotelm boundary of peat consists of the living plants and organic matter in the top $50 \mathrm{~cm}$ of the ground, while the catotelm lies beneath the water table, storing the dead organic matter ${ }^{54}$. The RAMSAR Convention, an organization that seeks to identify and protect Wetlands of International Importance ${ }^{55}$, defined peatlands as: "ecosystems with a peat deposit that may currently support a vegetation that is peat-forming, may not, or may lack vegetation entirely. Peat is dead and partially decomposed plant remains that have accumulated in situ under waterlogged conditions" 56 . This definition, however, does not include former deposits where extraction, mining, burning, or other eroded the peat.

Scotland is home to a substantial portion of the Earth's peat wetlands, adding additional environmental significance to the Highland territories. Peat wetlands act as a carbon sink, retaining significant portions of the world's carbon emissions in its soils. The soils dead organic matter and its highly saturated, acidic state creates excellent grounds for storage and preservation ${ }^{57}$. As such, it has a remarkable ability to store carbon. With climate catastrophe at hand, one could argue that this landscape is essential, almost sacred. It stores immense amounts of the worlds carbon emissions, making them critical terrains for carbon sequestration, and are the largest store of carbon in the UK. Degraded peatlands

53 Fenton, Scottish Country Life, 196-97. 54 Bruneau and Johnson, "Scotland's Peatland Definitions and Information Resources," 3.

55 "Homepage | Ramsar." 56 Bruneau and Johnson, "Scotland's Peatland Definitions and Information Resources." 57 Bruneau and Johnson, $1-3$ 
become a carbon source, releasing its contents back into the atmosphere. Demands for their preservation are becoming increasingly louder. Much of the Scottish terrain is made up of peat and it covers nearly twenty percent of Scottish land ${ }^{58}$. At a growth rate of Imm a year, these landscapes are fragile and prone to erosion and wildfires, causing the ground to dry and release the stored carbon back into the atmosphere,. As such, the maintenance and care of these landscapes come under scrutiny and play a pivotal role in debates over future land stewardship practices in Scotland.

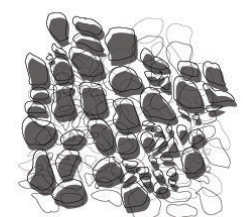

As Porous

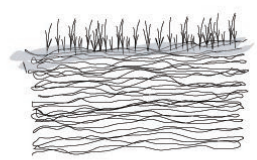

As Layers

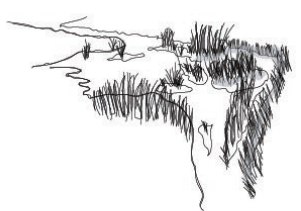

As Wettness

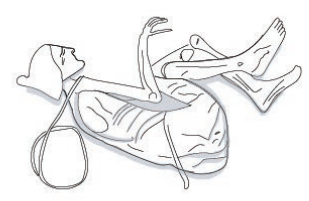

As a Burial Place

As Fuel

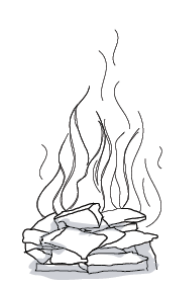

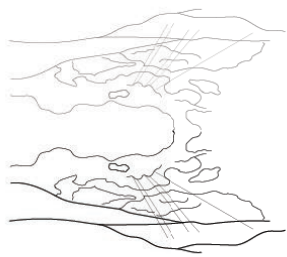

As a Thin Place

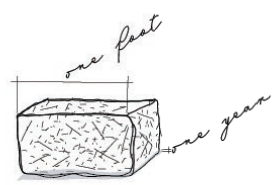

As a Unit of Measurement

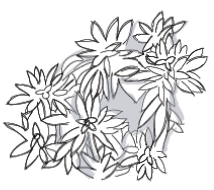

As Carbon Sequestration
58 Bruneau and Johnson,

"Scotland's Peatland -

Definitions and Information

Resources." 3-4

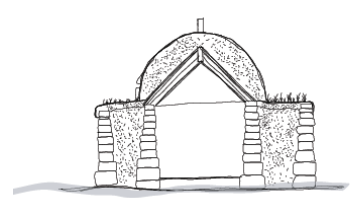

As Dwelling
Figure 15

Operations of Peat 
The Moor is a cabinet of curiosity, at the scale of a landscape. Bog bodies such as the Tollund Man have been found, dating back to $2500 \mathrm{BC}$, their facial expressions perfectly preserved. He is believed to be part of a sacrificial ritual on the moor, indicating the veneration and significance of these sites, of moors as burial places and sacrificial lands 59 . The bodies are enveloped in sphagnum and cocooned in an underworld of preserved moss. Two thousand year old butter, once an item of luxury, has also been found in peatbogs, stored beneath the surface, placed for retrieval at a later date, or perhaps as an offering to the ground ${ }^{60}$. Artifacts such as swords, weapons, wheels, and and canoes have also been found in peat bogs revealing intricate details of the past as they are unearthed.

Peat grows slowly. It accumulates at a rate of one millimetre per year, giving it a unique relationship with time. It becomes a unit of incremental measurement; measuring days, months, years, centuries in layers in the saturated, porous, unstable ground. These layers contain not only artifacts and bodies, but carbon data that reveals environmental conditions from past millennia ${ }^{6}$. This ground allows a glimpse into deep time, of an older, slower world; imprints of past life, ritual and atmosphere all contained in the shallow layers of peat. The depth of the ground becomes a timeline; at one metre deep the carbon discloses particulars from the year IO2IAD. Twelve meters predates the Anthropocene and provides a look into the last days of the Pleistocene and the retreat of glaciers as the earth warmed into the Holocene. ${ }^{62}$ Understanding the operations of peat formation (Fig. I5, Fig. I6) provides a reading of the human existence that has been, is, will be, and beyond; the moor and peat are elements of deep time (Fig. I7). Robert Macfarlane writes, "Deep time is measured in units that humble the human instant : epochs and aeons, instead of minutes and years...Deep time opens into the future as well as the past." ${ }^{33}$ The average lifespan of a woman in the United Kingdom is approximately eighty-three years of age $^{64}$, less than a centimeter of growth in peat-time. Peat helps re-order our relationship and understandings of time.

Perhaps peat landscapes remind us of the fragility of human existence,

61 Turetsky, Manning, and Wieder, "Dating Recent Peat Deposits."

62 Dyakonov et al., "The Age of Peatlands and Peatland Formation Stages in Polesie Landscapes of the East European Plain." 63 Macfarlane, Underland, 15. 64 "National Life Tables - Life Expectancy in the UK - Office for National Statistics." 
of the generations and beings that have come before us and those that will be there long after we are gone, adding to the unsettling, unknown of it all. Tales of 'the will o' the whisp' or ignis fatuus, the foolish light, (phosphorescence released by decaying gasses) is said to lead people astray over the moors, and strange sounds emerge from a decaying ground. The physical qualities of the terrain deepen the mysticism adding a layer of the supernatural to these sites and provide a spatial experience from which to draw upon. Contemplating the sensations of space in relation to the ground has profound effects in film, literature, and reality, and not just about the physical elements we can see. Architectural historian Iain Borden points out that “...[these] enquiries help us realize that architecture is not always a matter of plan, section, and elevation, but also an affair of impression, psychology, reaction, smell, listening, emotion, and bodily movement. ${ }^{35}$
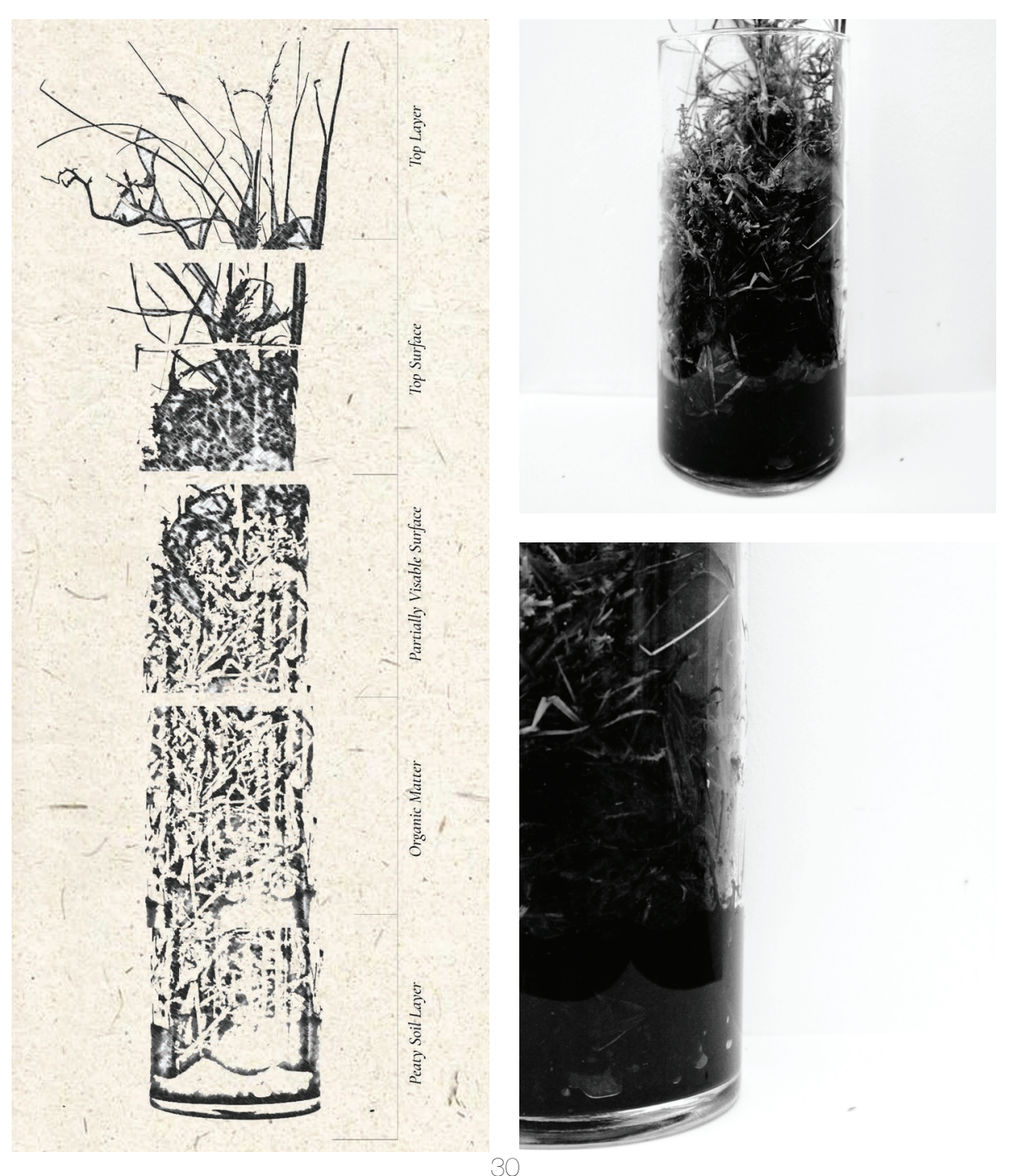

65 Handa, Potter, and
Borden, Conjuring the

Real, 11.

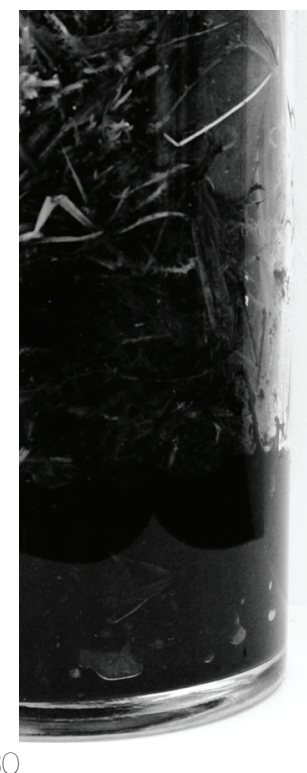




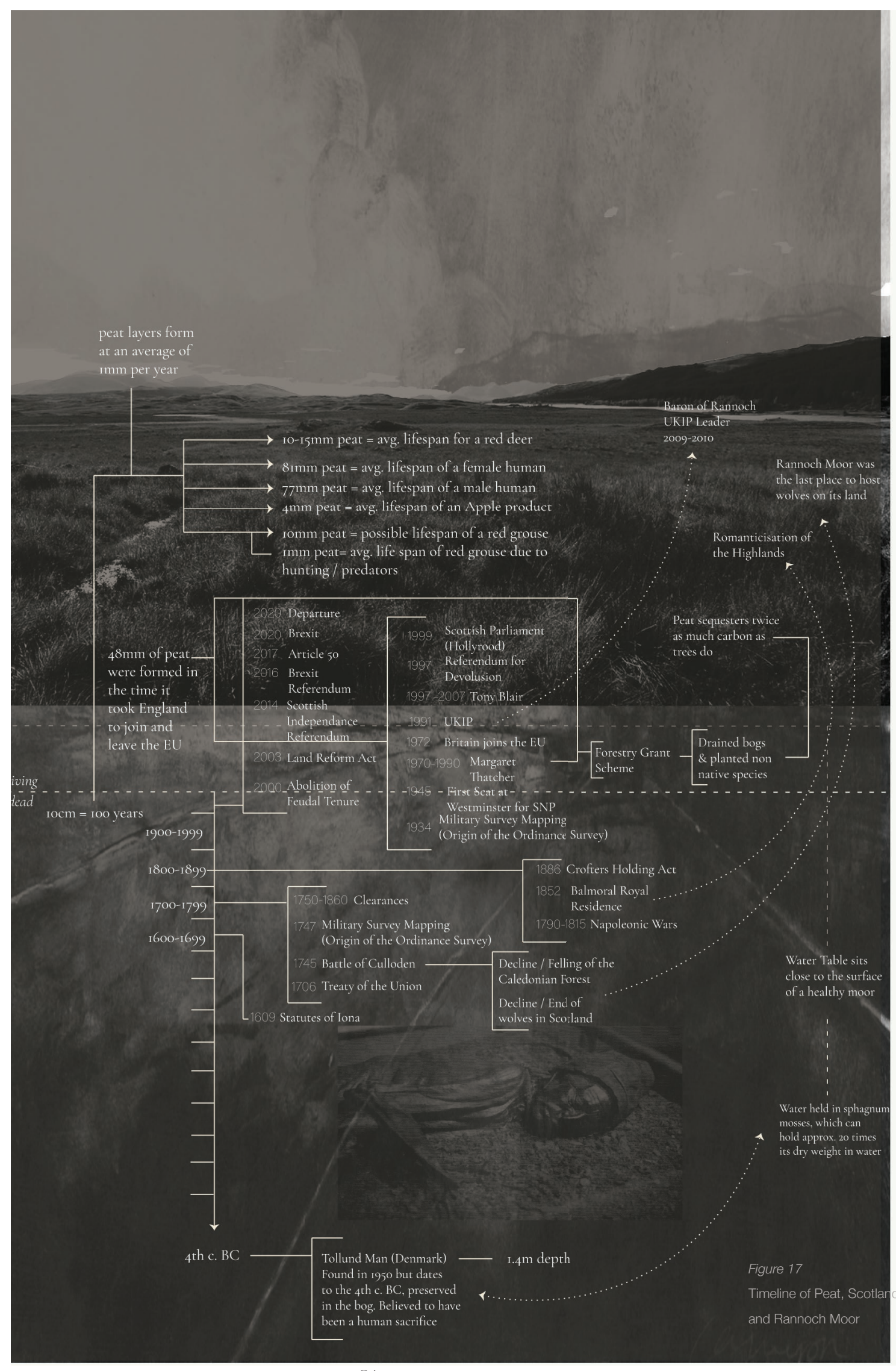


chapter is

Rannoch Moor
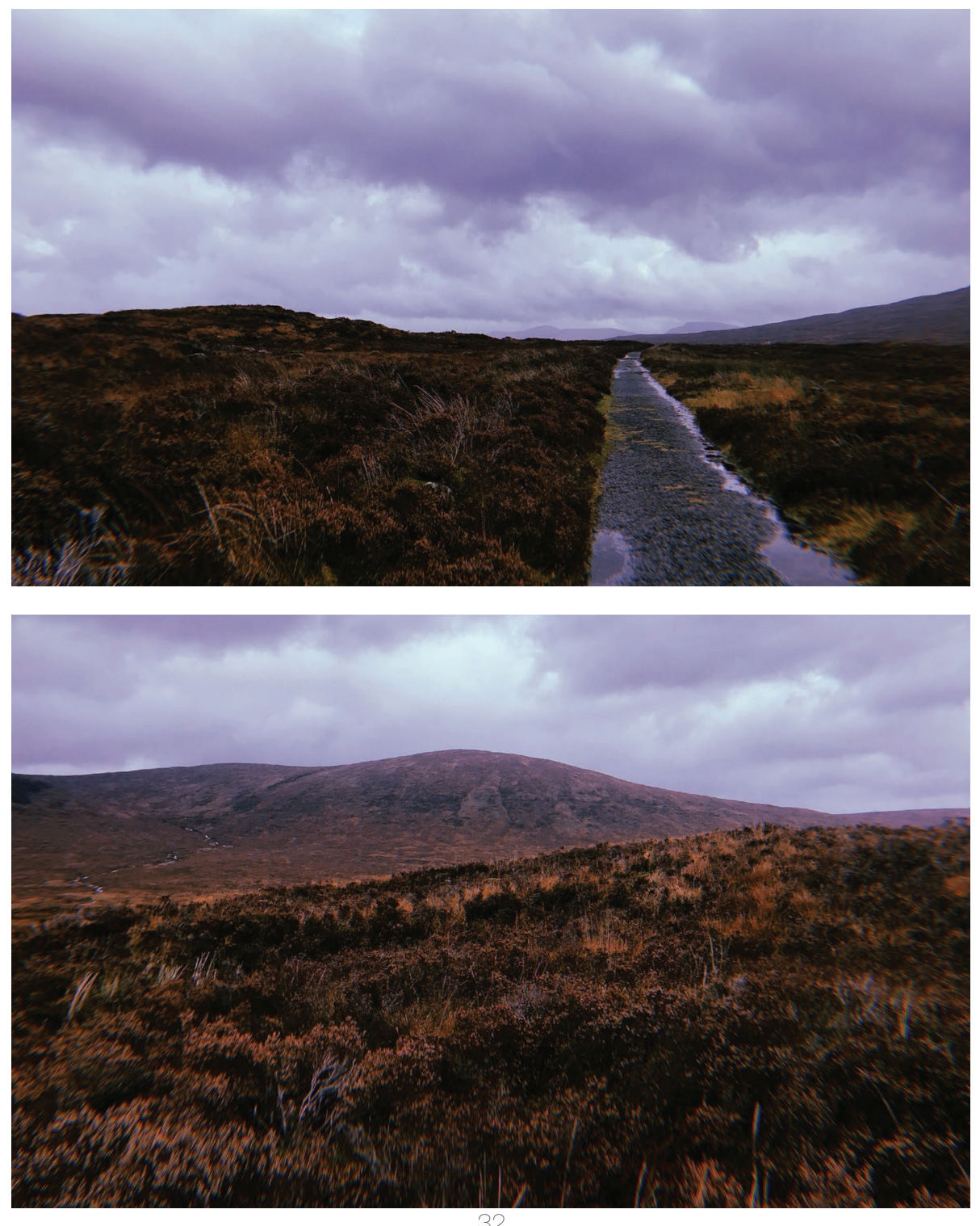

Figure 18, 19

Rannoch Moor, 2020 

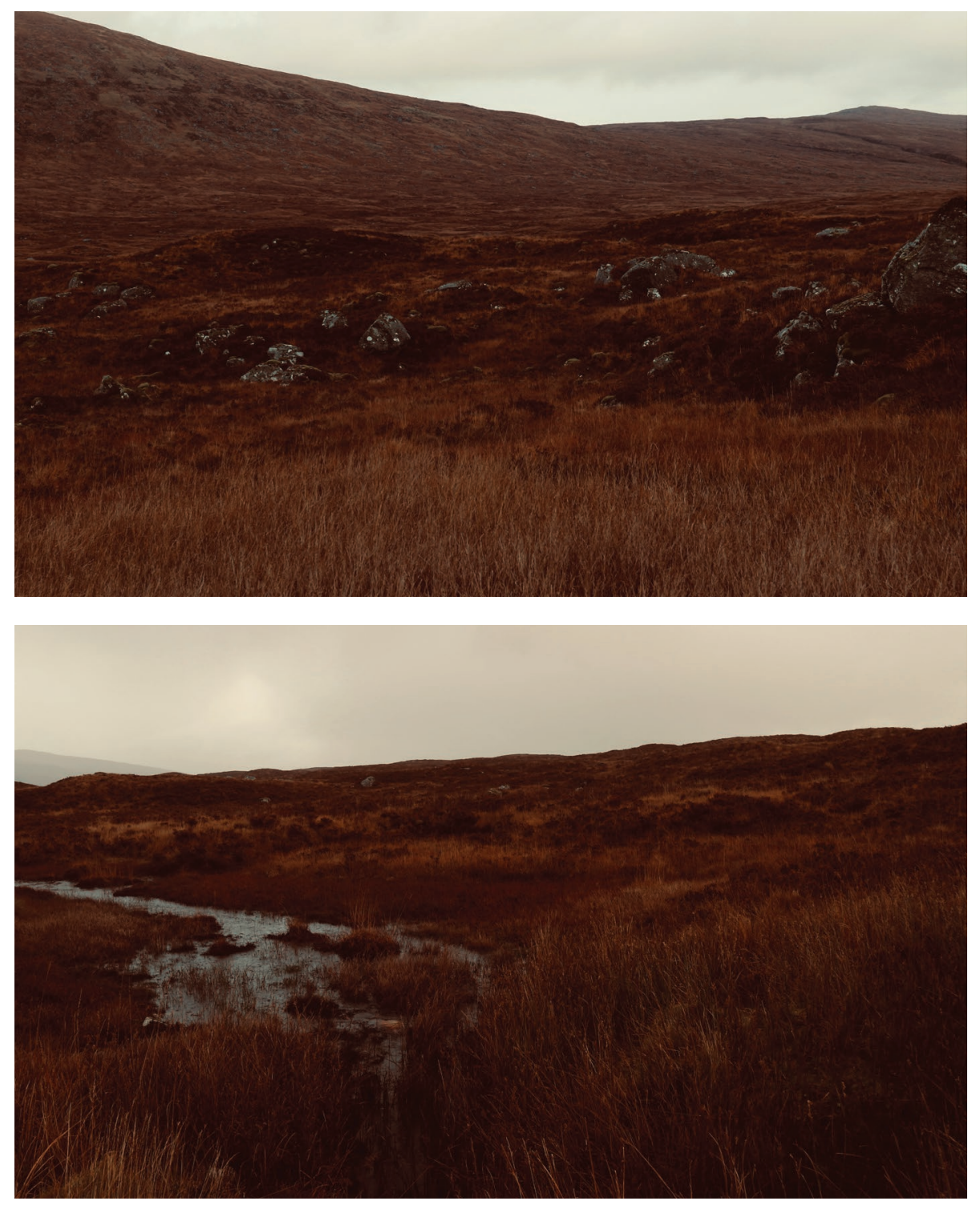

Figure 20, 21, 22

Site Photos

Rannoch Moor, 2020

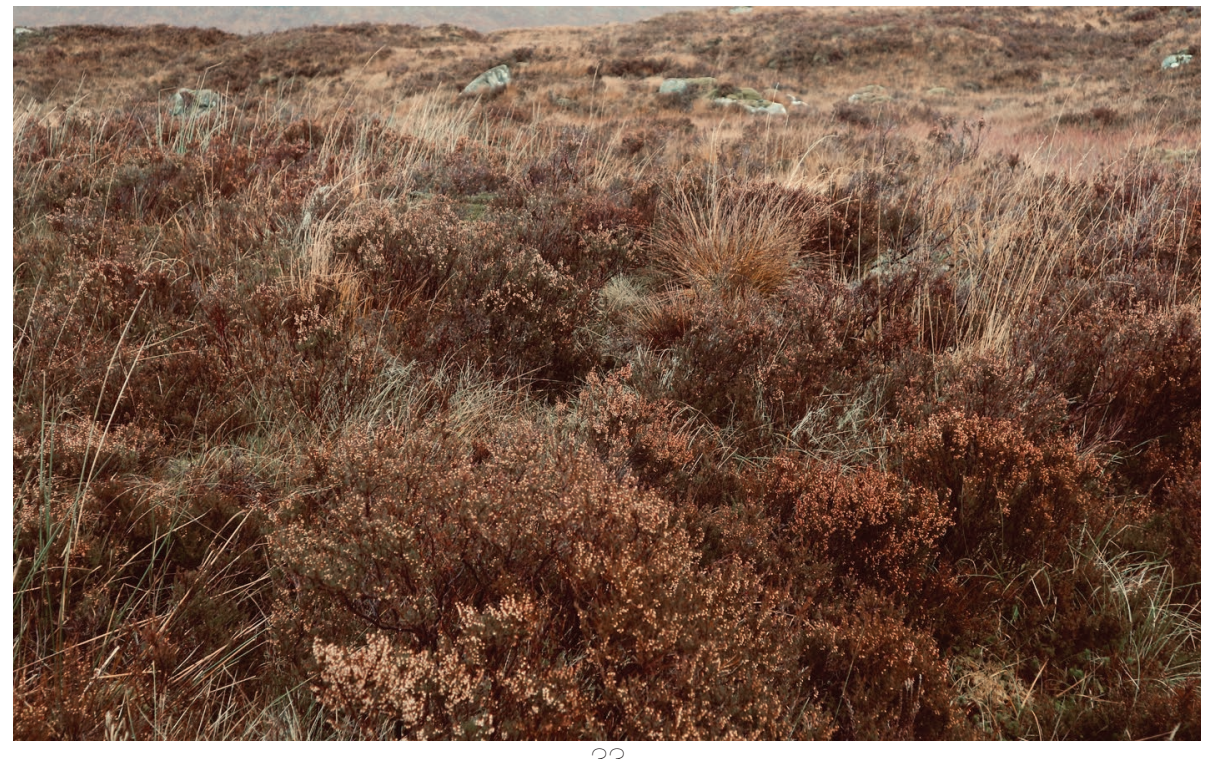


achel Hewitt and Robert Louis Stevenson helped provide the
site for this thesis; Rannoch Moor. Historically the moor served
as a base for surveying the Highlands after the fall of the Jacobite rebellion in 1745 . It became, as a result, a critical terrain in the relationship between England and Scotland. As the territory was unfamiliar to the English at the time, surveying methods were employed to gain knowledge and control over the territory and its peoples. Stevenson depicted the moor as a space for hiding, a place of unseen activity. The dichotomy between the desire to see and not see in these narratives - the politics and relationships of spatial equity - were key for the thesis.

IV.II The Visit

In the Fall of 2020 I moved to Scotland in order to be close to my site. There have been challenges for accessing the site (COVID-rg and lockdowns among them) regularly, however occasional site visits were possible and proved invaluable. Much of the site research has relied on the local community. The Rannoch Moor railway station has a small visitors centre and museum that provided details and context that was unavailable or unclear through other sources. The Rannoch History Society publishes locally made booklets about the area that cannot be found in any library or database. Many of the accounts and stories of the moor are from oral histories, passed down through family narratives ${ }^{66}$. Alec Cunningham, the

66 Cunningham, A History of Rannoch Moor, 5. 
local historian, took the time to listen and record the events and stories of Rannoch Moor so that others could inform themselves about the rich history.

Rannoch Moor is an expanse of boggy landscape that sits in the central highlands in Scotland. It is designated as a site of outstanding beauty and is home to lochs, mountains, peat bogs and diverse plant and animal species. it is a historically significant site, famous for Jacobite hideouts, feats of floating railway engineering, massacres, stories of clansmen and wolves, and central to the formation of the Ordinance Survey.

The Moor is famous. It has been used as filmic background and context (Harry Potter and Outlander, for starters). Its shifting weather, dramatic vistas and unsettling vastness make it a prime location for mystery and fantastical stories. Its darker history includes the site of the Glencoe massacre. In 1692 the Clan MacDonald families were killed in their homes while hosting royal soldiers, punishment for stalling their pledge of loyalty to the crown ${ }^{67}$. It is also is host to many tales and stories of strange occurrences while walking in the landscape. Some date back to the days of droving cattle through the $\operatorname{mud}^{68}$, some are more in recent, with one hiker confessing the moor left her “...questioning what I saw or didn't see, what was real and what couldn't possibly be." ${ }^{99}$

67 Fletcher, Corrag.

68 Cunningham, Tales of

Rannoch.

69 Clark, "A Spooky

Scottish Story Straight out

of Outlander - The Globe

and Mail."

70 Cunningham, Tales of

Rannoch, 76.

\section{IV.III The Access}

"One day a traveller, on his way back from Kingshouse to Rannoch, was half way across the moor when the mist thickened. The way had been desolate and he had difficulty in following the path which frequently disappeared among large rocks and treacherous bog. Just as he rounded a knoll, he stood silently listening. He had heard something. The solitude was broken by the sound of footsteps. He looked back; someone was following him. The footsteps came closer, and he peered into the mist, expecting to see a gamekeeper or a fellow traveller. He noticed that the air had become so chill that he shivered. He began to feel very uneasy..."

- Tales of Rannoch 
The Moor is accessible from the west via the A82 motorway, and the A9 from the east, however there are no through roads that connect either side of the moor (Fig. 23). The only way across is by a public footpath that leads from the Kingshouse Inn to the Rannoch Train Station, or via the trainline that cuts through the moor. The construction of the train was completed late $19^{\text {th }}$ century. Due to the moors unsettled ground, thousands of tons of ballast were lost into the ground, unable to provide a stable foundation for the railway. In order to secure a stable foundation for the railway, the engineers decide to 'float' the rail line on a raft of brushwood and heather, followed by ash and rubble ${ }^{71}$ (Fig. 26). The public pathway stretches from the A82 near the Kingshouse Hotel - a popular rest stop for walkers - across the moor to the Rannoch Train Station. Travelers who cross the moor have claimed they have felt presences that were not there, seen apparitions of An Duine Eagalach (the Egg-Faced Man), or been guided out of harm's way by supernatural forces ${ }^{2}$.

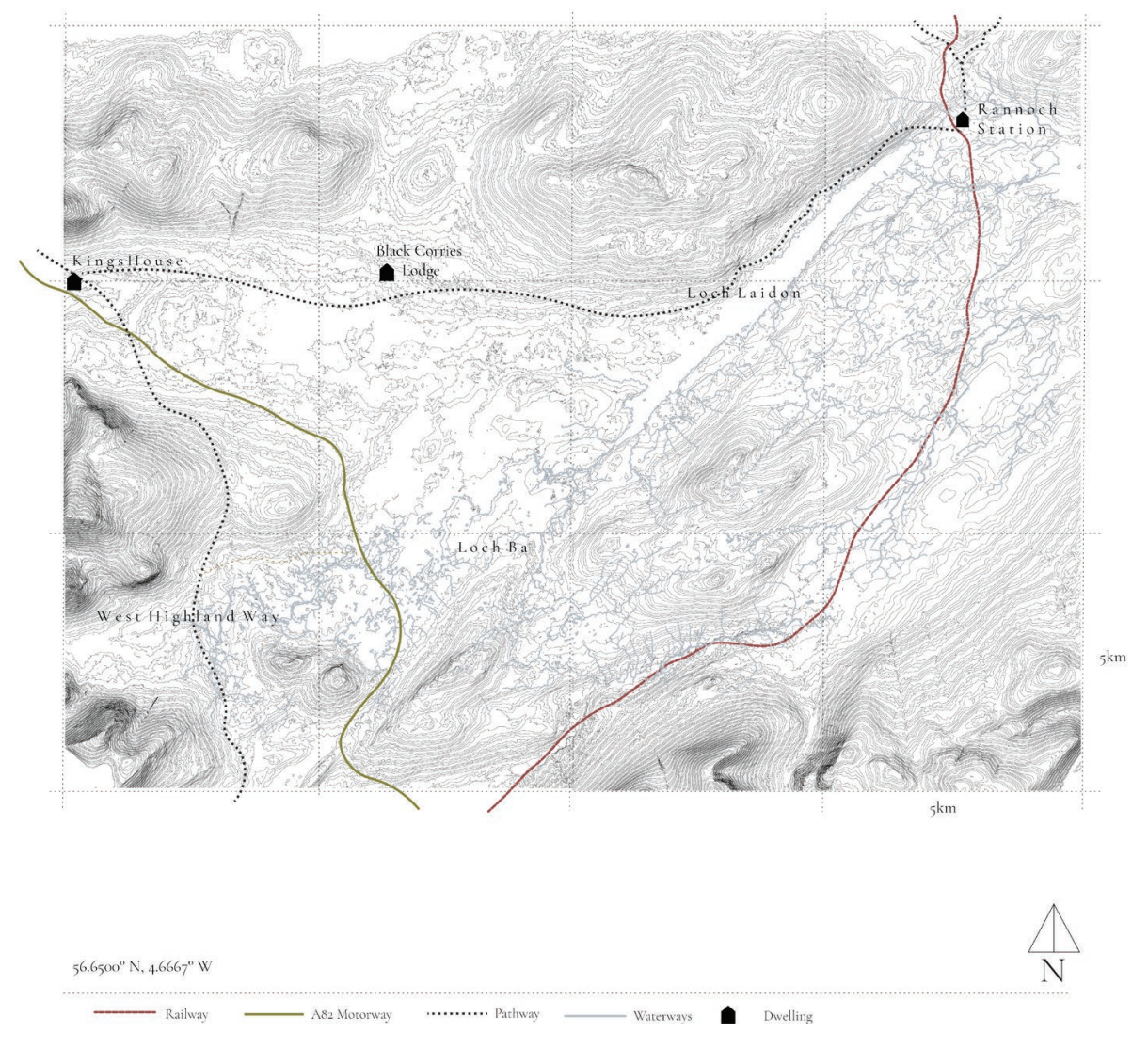

71 Rannoch Visitors Centre, "Building the West Highland Line." 72 Cunningham, Tales of Rannoch, 75-77. 

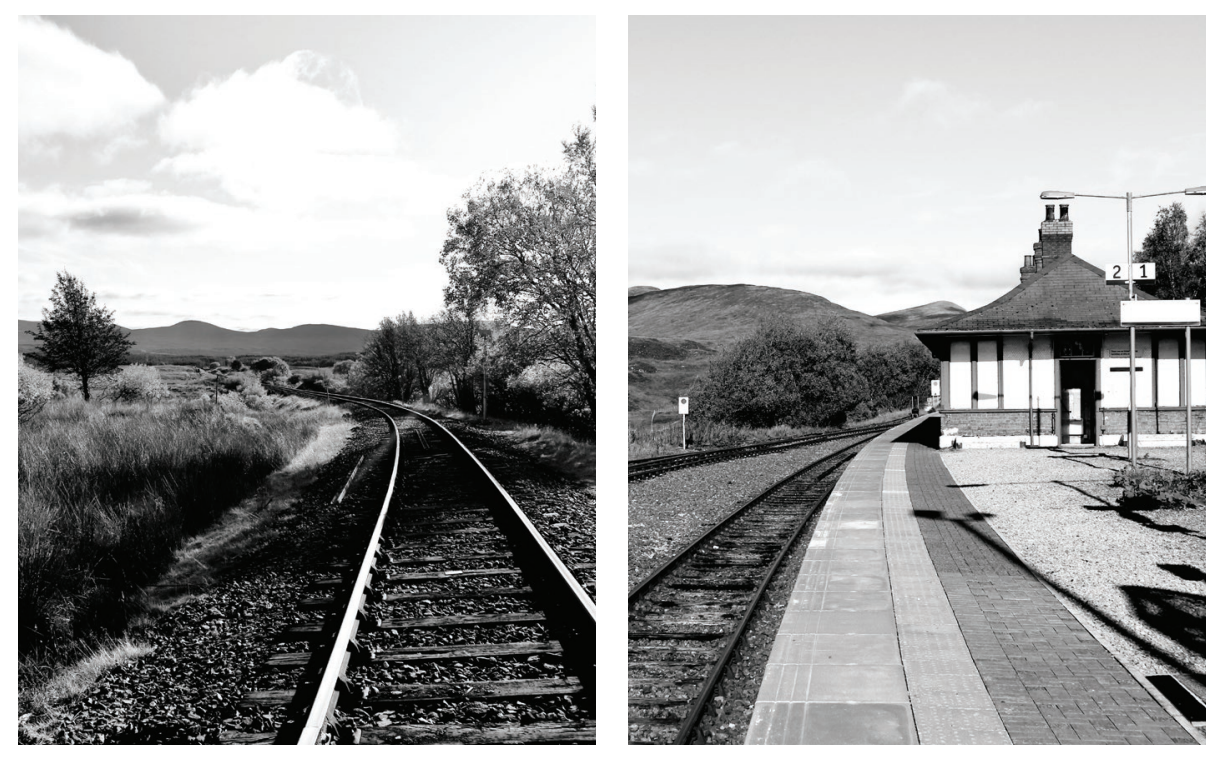

Figure 24, 25, 26

Clockwise from Left: Railway and Rannoch Moor Station

Rannoch Moor 2020

Railway Track Assemblage

Diagram

Typical Railway Track Assemblage

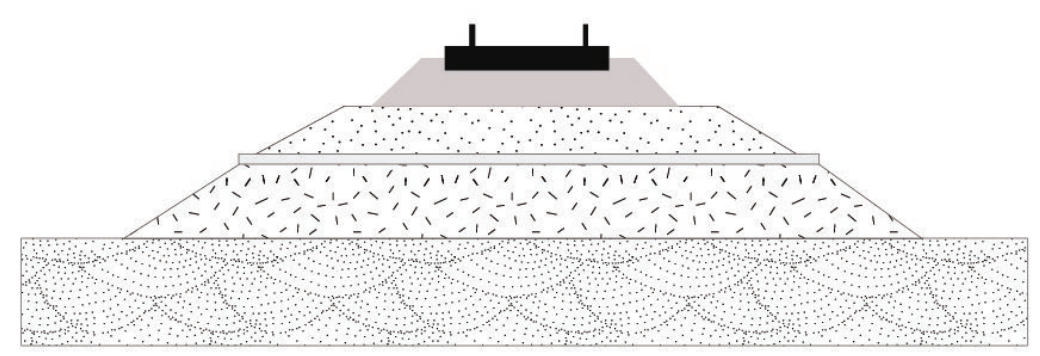

Rails
Sleepers

Ballast

Subballast

Blanket

Subgrade

Subsoil

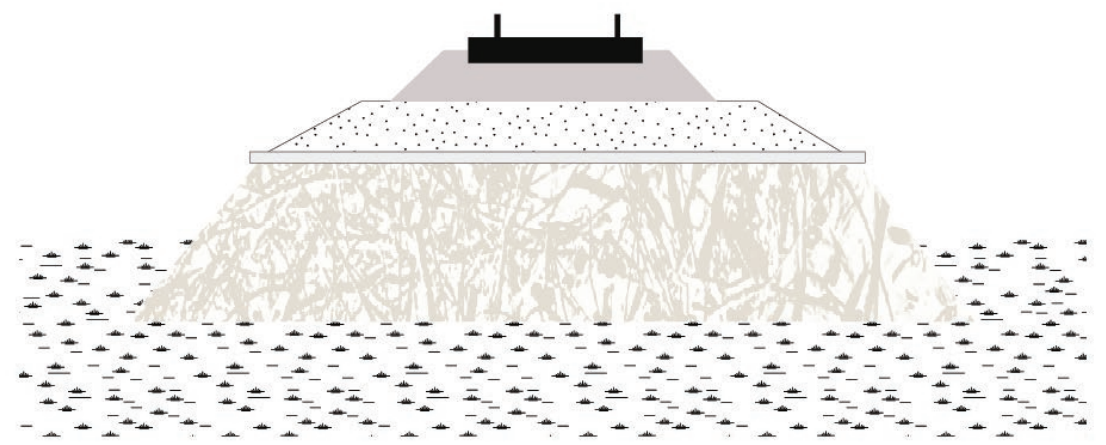

Rannoch Moor Rail Line Assemblage

Rails

Ballast

Subballast

Blanket

Subgrade : brushwood, ash $+\operatorname{logs}$

Subsoil : peatland

Water content high 
It is designated a Site of Special Scientific Interest (Fig. 27) and is listed under RAMSAR as a recognized wetland (hosting ample peat deopsits, Fig. 28, 29). There is one private hunting estate on the moor, and listed on the Scottish Land Registrar as belonging to the Baron of Rannoch, former UKIP party leader Sir Malcolm Pearson ${ }^{73}$. Unlisted is the Black Corries Estate, which according to a local hotel manager, belongs to the family of the Stella Artois franchise. It is also a hunting estate, available for reservation at around £3,350.00 per week. On the estate, visitors can hunt deer and grouse as well as fish for salmon.

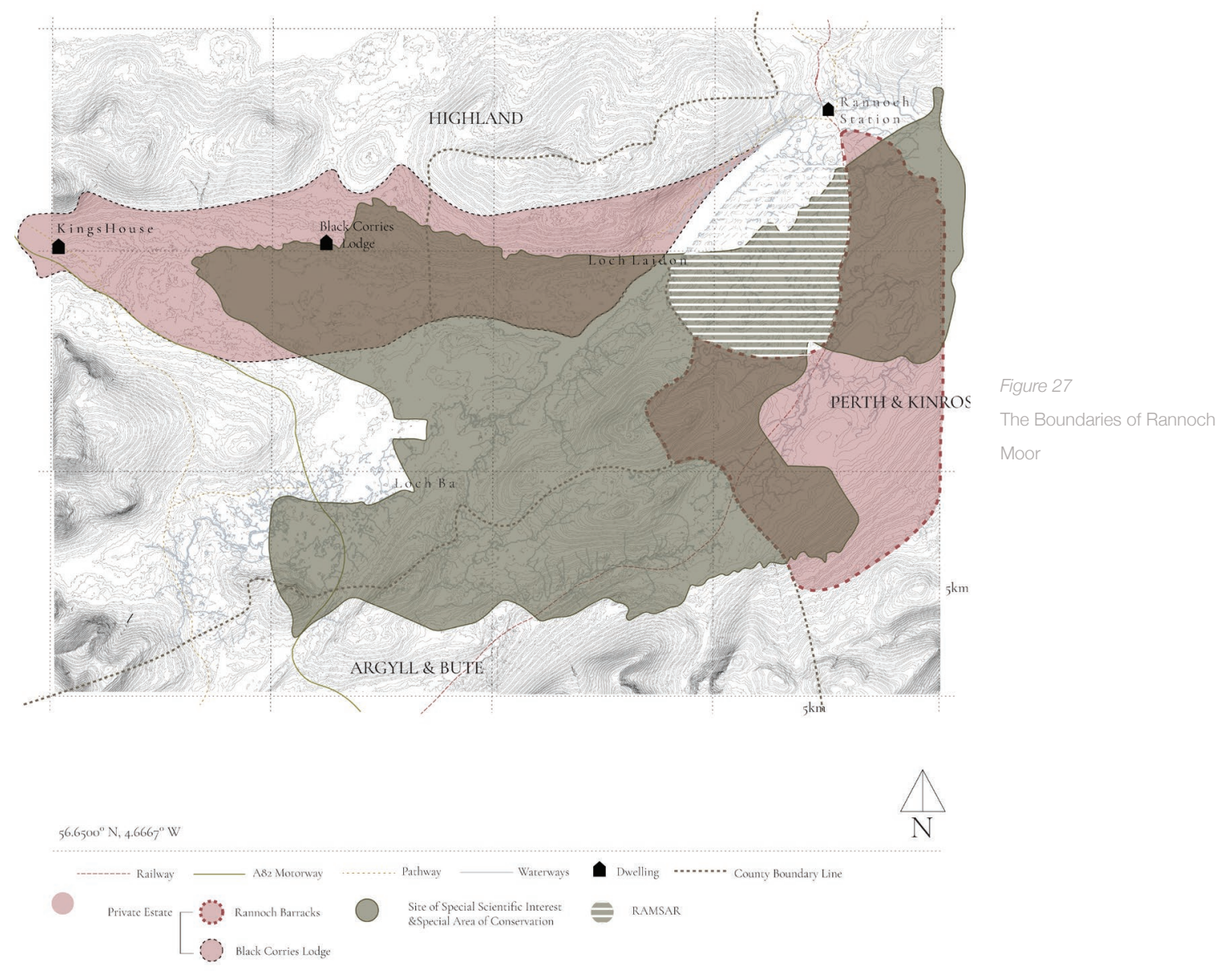



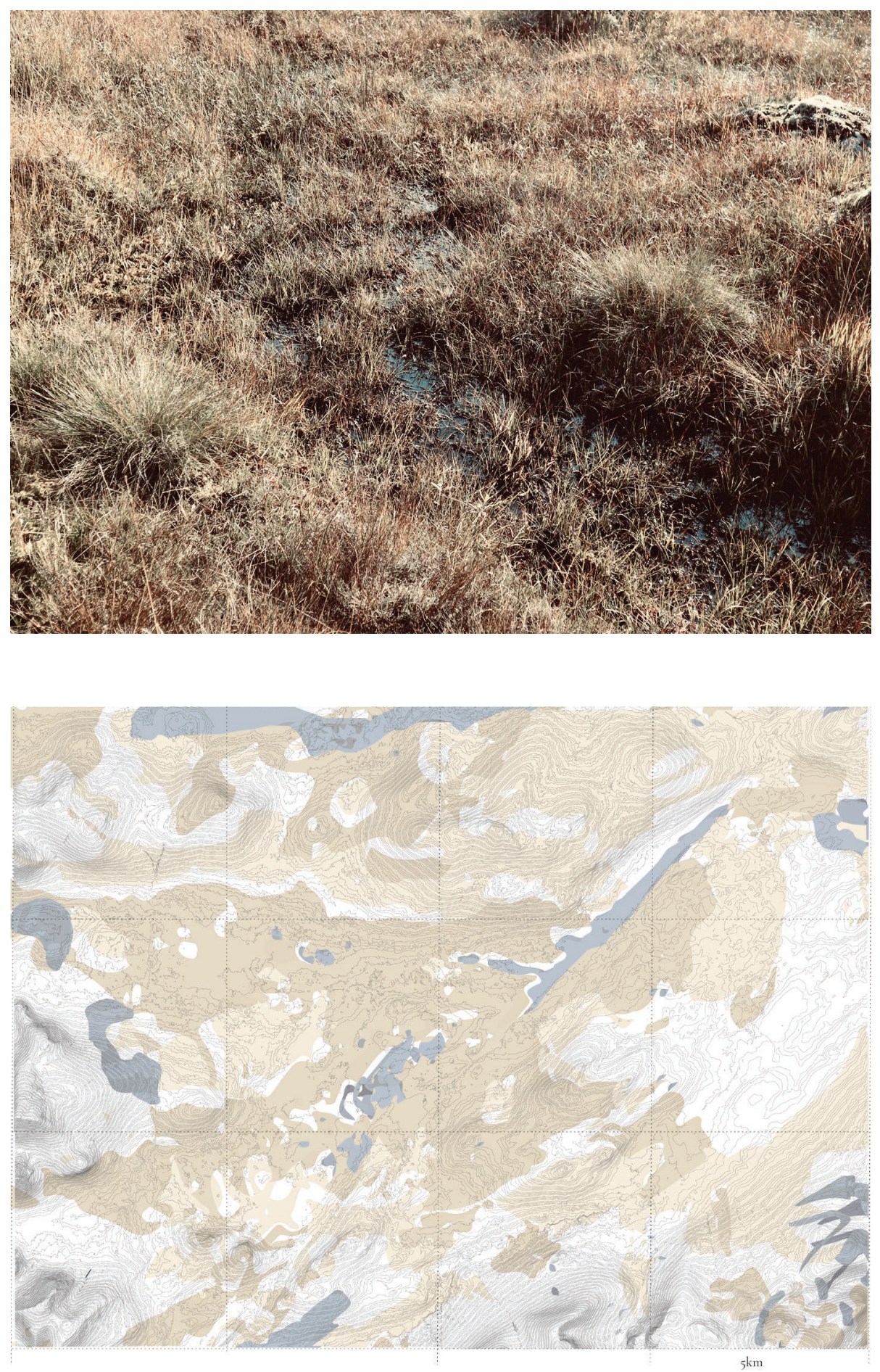

Figure 28, 29

Top: Wetland Moor Ground

Cover

Bottom: Peat Coverage,

Rannoch Moor.

$56.6500^{\circ} \mathrm{N}, 4.6667^{\circ} \mathrm{W}$

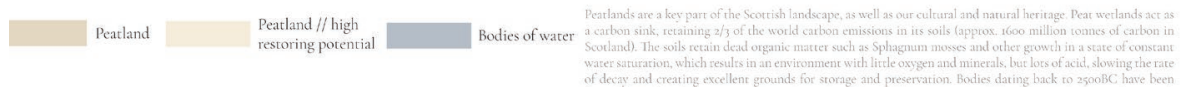


In addition to the physical routes, there other points of access into site that go beyond the purely tactile and tangible and delve into the realm of memory. Rannoch Moor is formed and accessed through sites of memory and story that give meaning to the landscape. How does place exist in the mind? How do you access this meaning? Stevenson and Conan Doyle, Milton, Atkins and Shepherd and the Ordinance Survey have guided us to some of these grid mapping, mark making, literature and storytelling, historical events and more that begin to form the memory of the site. The site begins to take form in the mind through physical markers, certain stones, and hilltops, the stories of these places creating a timeless access to the site. The Heart Stone on the Road to Isles offered travellers a navigational sign that they are near Rannoch Moor in the days of droving. The stone remains, as a physical mark on a trail, as a story of days past, and as guide for travellers who walk the pathway for leisure. The peak Buachaille etive mor (Fig. I) or "The Herdsman", gets its name from its sentinel like presence, marking the gates to Glencoe and herding creatures

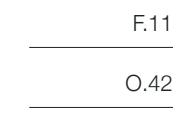
through the pass, watching over the moor, or the distinctive hills (seen in figure I4$_{4}$ ) that provided refuge for the Macdonald clan as they fled for their lives, the massacre of their families living on in the memory of place. These elements imprint on the meaning of the site through memory, imagined scenes, stories, and language, preserving it in time for others to access. Accessing the moor is not just about the physical access points that are identifiable on a map - they are the points of memory that hold meaning to those that traverse and consider the landscape as more than just a physical place. Any future speculation requires consideration for both the physical and non-physical modes of access.

\section{IV.IV The Scene}

The landscape is vast, free of trees and prominent physical markers (Fig. 3o) aside from an occasional structure or large rock. Space is different on the moor. Perspective becomes altered and distances are not what they seem. The horizon is in view, but is appears closer than it is. The atmosphere on Rannoch changes daily; the light, weather, ground cover, and air, play with the mind. Scottish artist Dominique Cameron captures the dramatic scene of the moor in her evocative drawings (Fig. 3I, 32). 


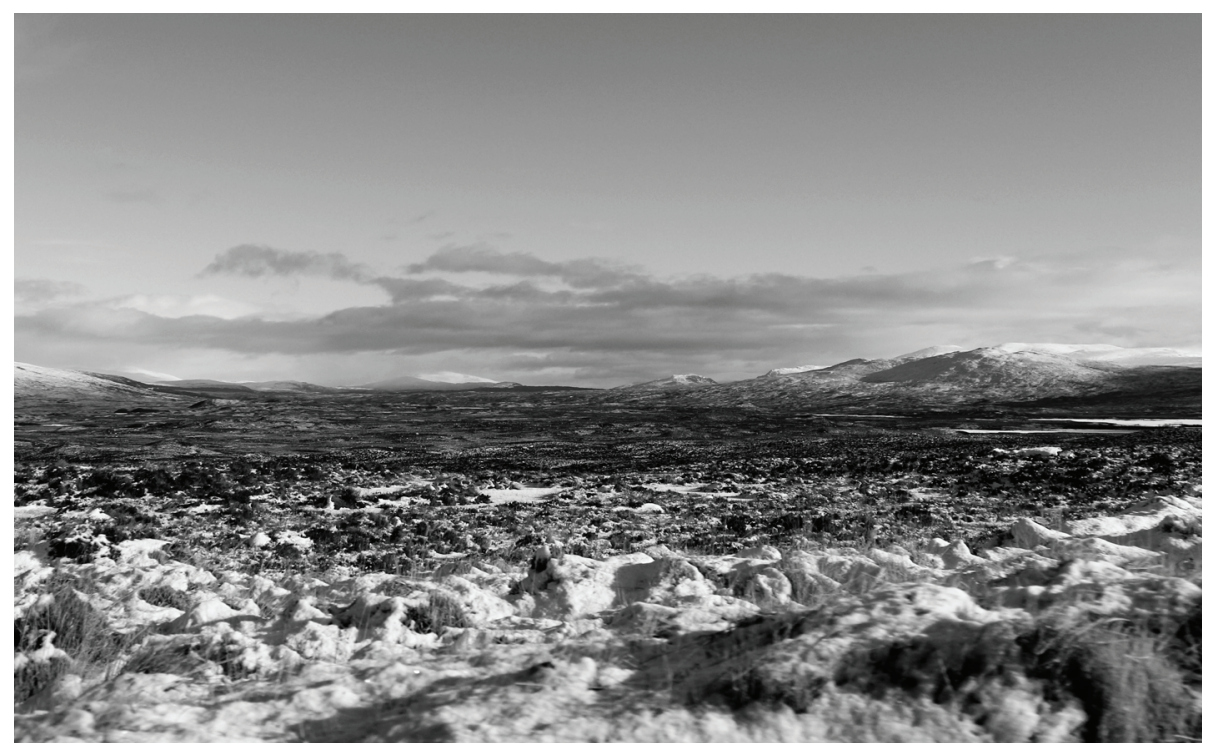

Figure 30

Rannoch Moor Lookout, 2021

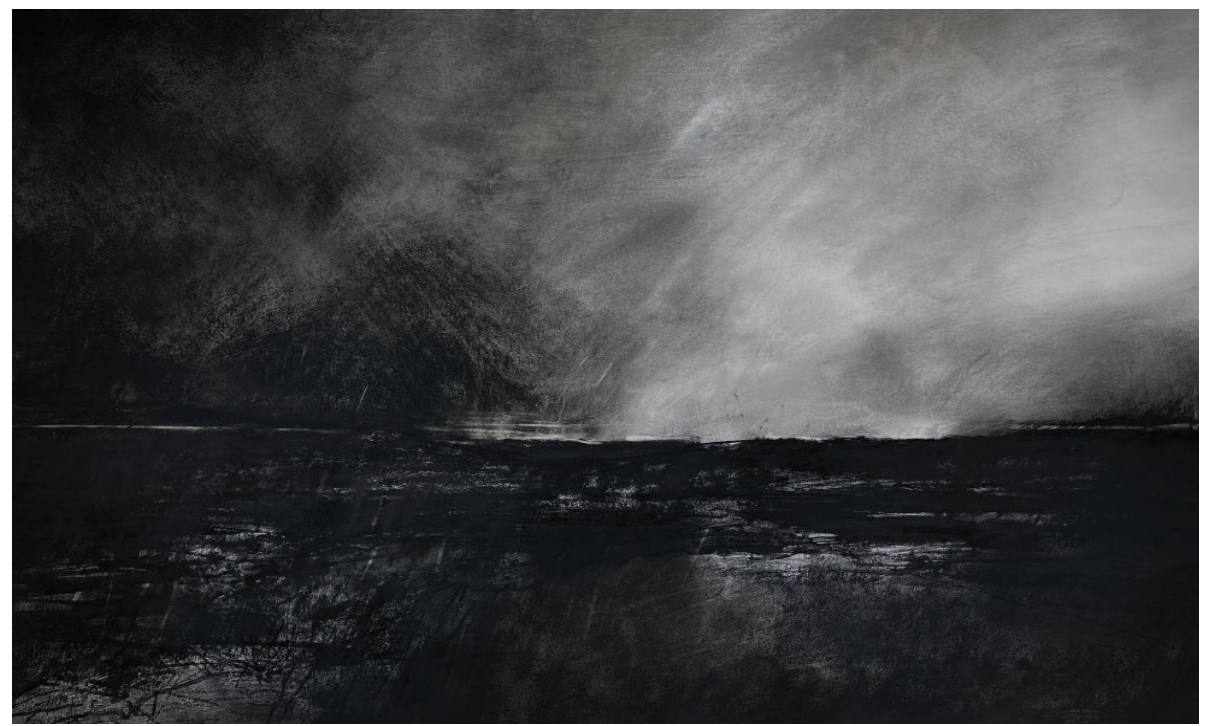

Figure 31, 32

Cameron, Dominique. Moo

Series, Charcoal on Paper,

2020 (Rannoch Moor)

https://dominiquefcameron.

com/portfolio/rannoch-

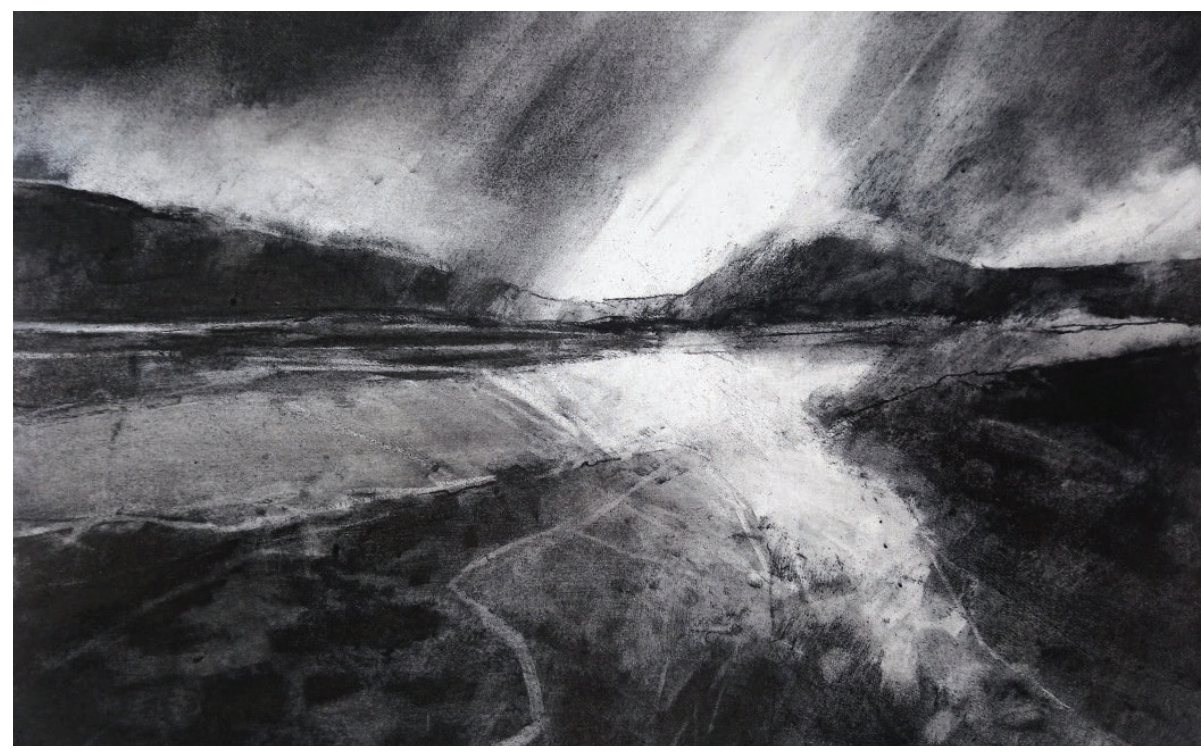

moor/ 
Rannoch sits at a latitude of 53 degrees north, so in October and November the sun stays low, the golden hour lasting all afternoon (Fig. 33). There is a maintained pathway to allow access from the train station to the west side of the moor, however leaving the path is ill advised as the terrain is boggy and far wetter than it looks. A quick hop onto the moor proved wet and squishy, water pushing out from under the pressure of my foot. Deer manage to navigate it gracefully, a seemingly impossible task on such spindly legs.

The moor does not provide a stable surface, both mentally and physically. It sinks and shifts, and in doing so, invite questions of how we intervene in and on and over the ground. They are ideas that celebrate and question foundations (Fig.34 ) - both as a physical act of emplacement, as a metaphorical notion of place, identity or politics, and both of which contribute to the traces left by those who have made place on the moor. Contemplating the unsettled conditions of the moor floats questions about surface engagement. How does one build or make place on a landscape that is amphibious in nature - both land and water. Resourceful methods of 'floating' using brushwood and heather have been used to create (semi) stable structure on its surface. Sinking is a natural process within the geology of the moor, so how do you built on it, into it, or allow it to adapt to the ground? How do you design in and for a changing landscape?

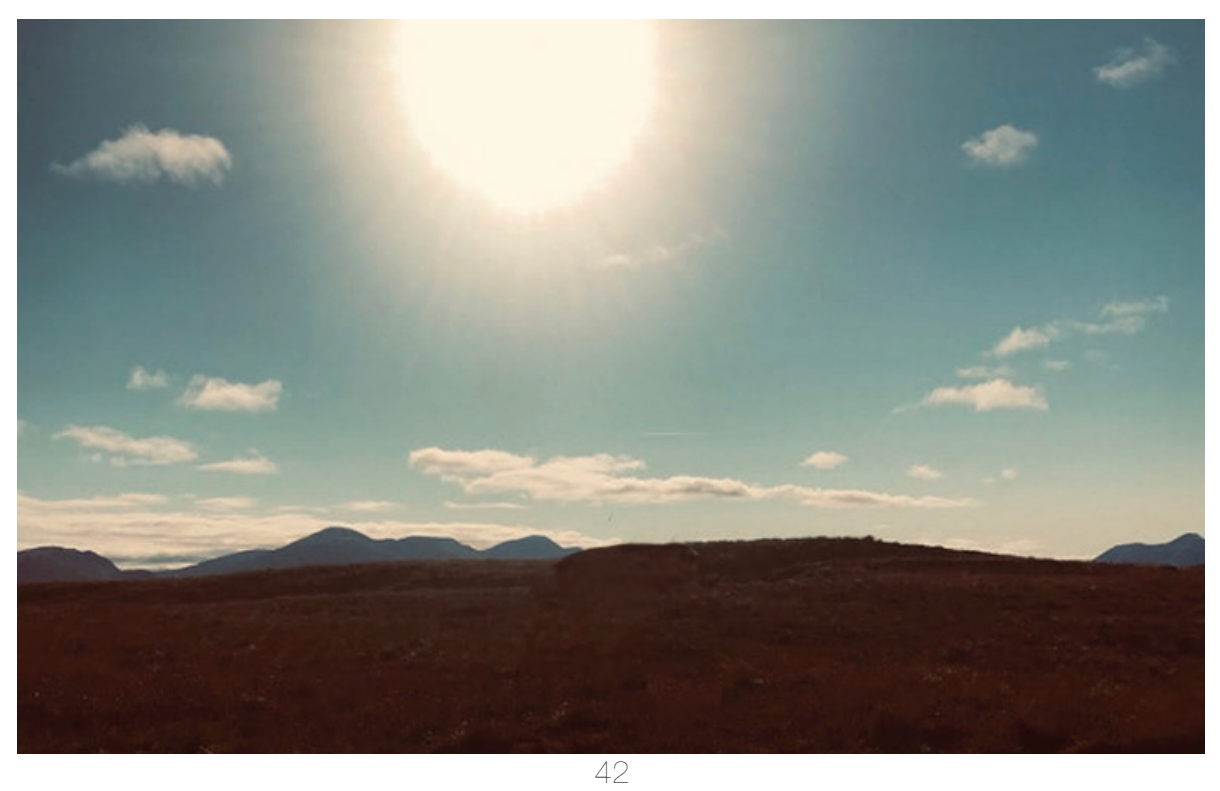




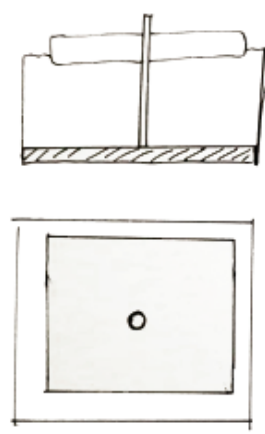

centred pole anchor
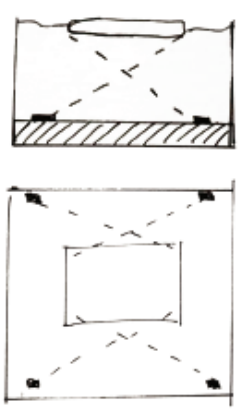

cross chained anchor
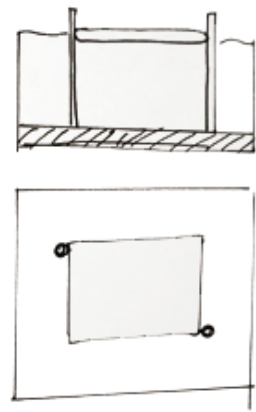

poles on 5 des anchor r Makoko

Floating

School

by NLE,
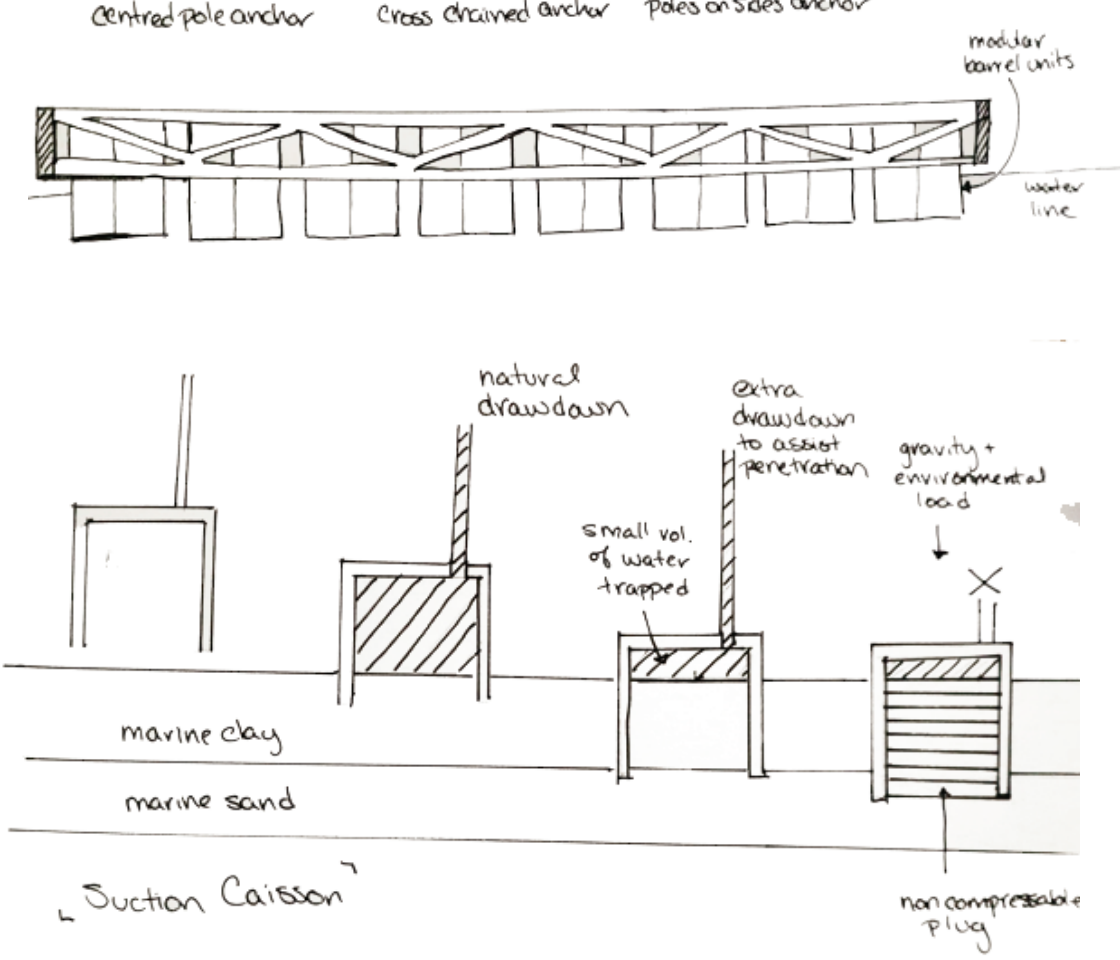

Figure 34

Surface Engagement

Sketches

Exploring unusual, shifting,

or adaptive foundation

building techniques.

Foundations that engage

with different surface

conditions.

From Top (left to right): NLÉ Makoko Floating School.

Lagos, Nigeria, 2012. http://

www.nleworks.com/case/

makoko-floating-school/,

Suction Caisson, Limpet,

Trans-Alaska Pipeline

Foundation example.

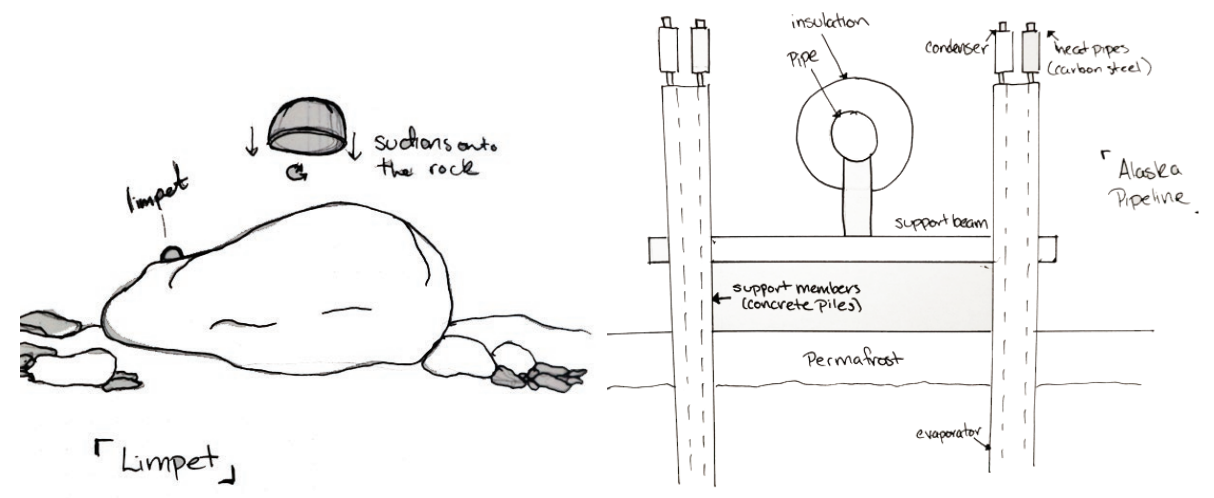


... [ask] not to what critters are supposed to be able to do, by nature or education, but to what beings evoke from and with each other that was truly not there before, in nature or culture. ${ }^{74}$

\section{- Donna Haraway}

The moor is a pluriverse of relations (Fig. 36). The flora and fauna (Fig. 35) listed by the Site of Special Scientific Interest indicate species that are deemed valuable ecosystem elements and include otters, Rannoch rush grass and dwarf birch trees. The hunting estates add to this pluriverse, with their own relational and unique ecologies and programs, and in doing so, cross boundaries and thresholds. Deer eat the grasses that halt the growth 74 Haraway, Staying with the Trouble, 7 of trees that might infringe on the hunt. Grouse lay their eggs and hide in the rushes and heather of the surface growth. The highland pony carries the deer carcass off the moor and back to the hunting estate. The off-road vehicle is needed to cross the boggy landscape that would envelop the tires of a standard car. These relationships go on and on. They do not, however, abide by the 'official' delineations of the landscape such as property lines or conservation efforts (Fig. 37). As Dilip da Cunha argues that just because we draw a line to indicate a river, does not mean the plants and animals see what we see, or that the river is in fact, bound by that colonizing line. The moor works in this way, too.
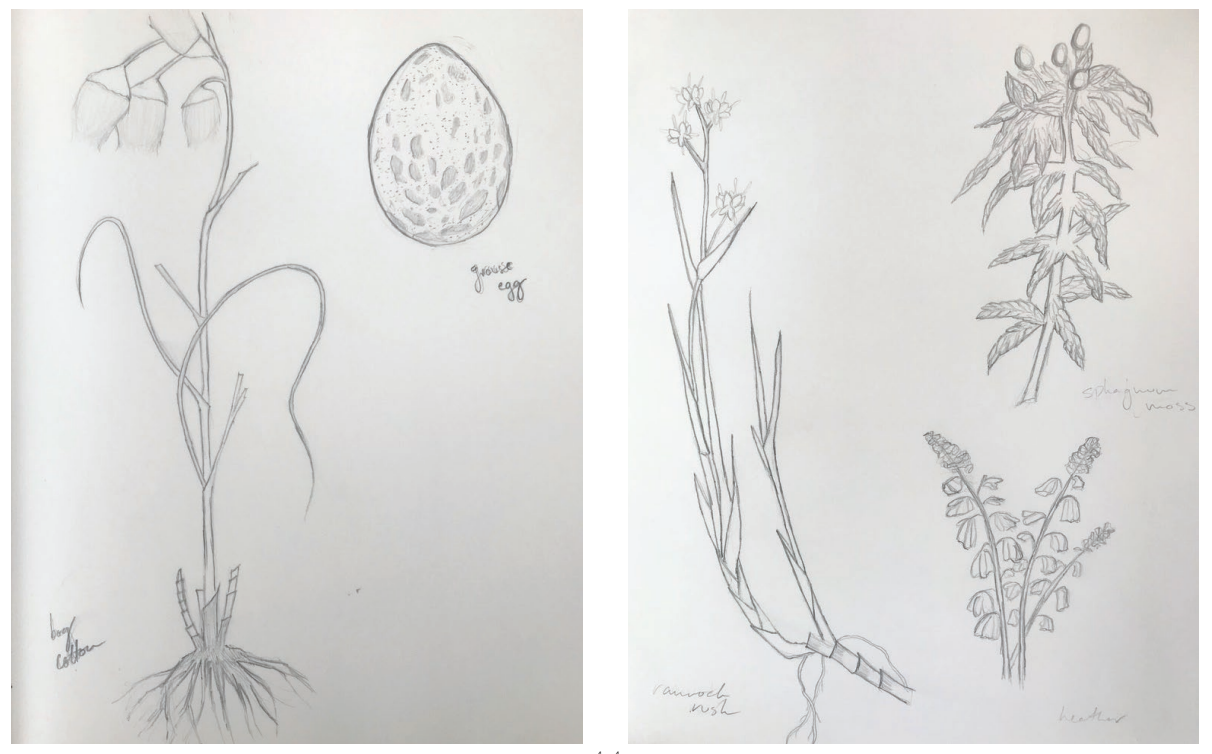

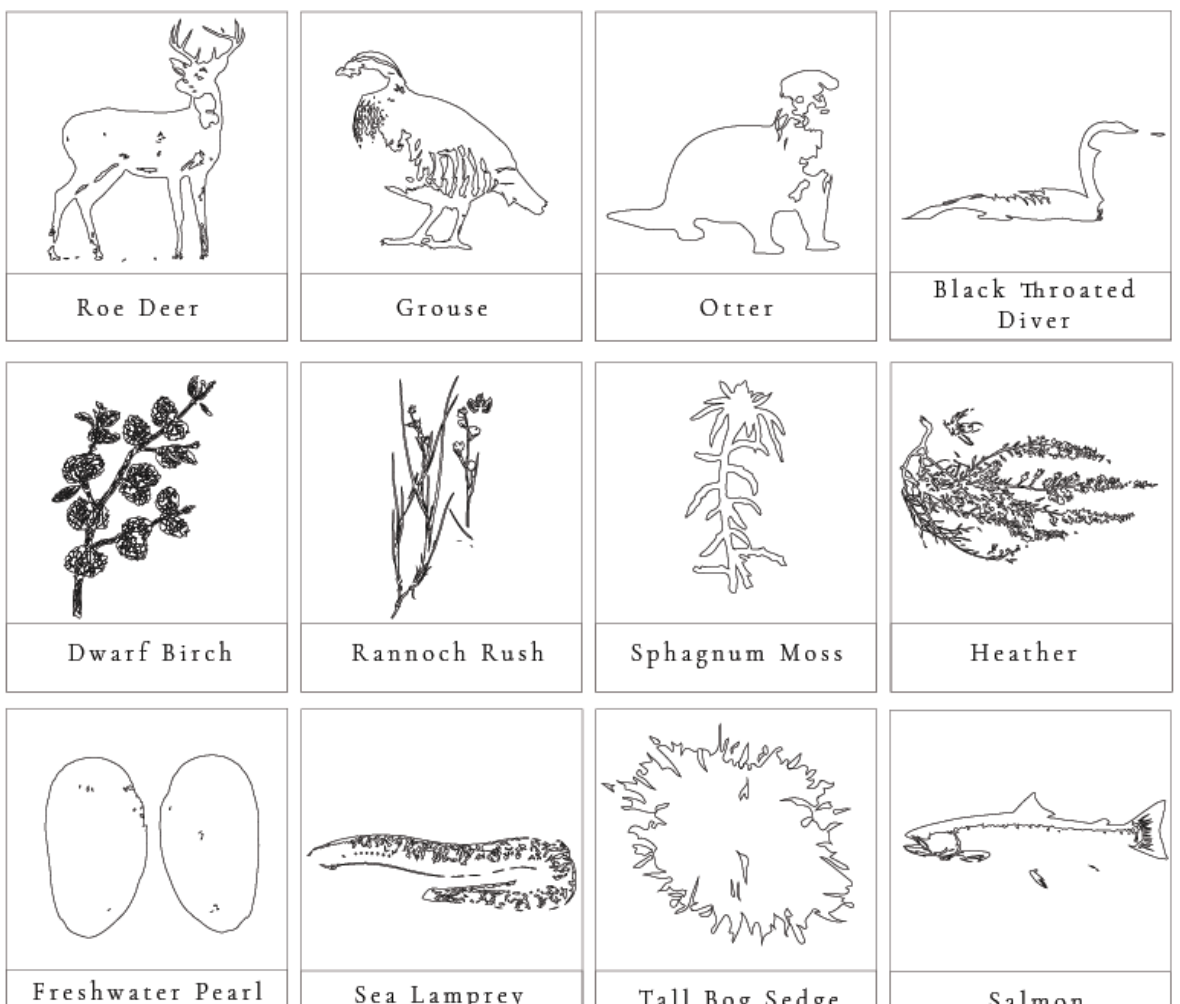
Muscles
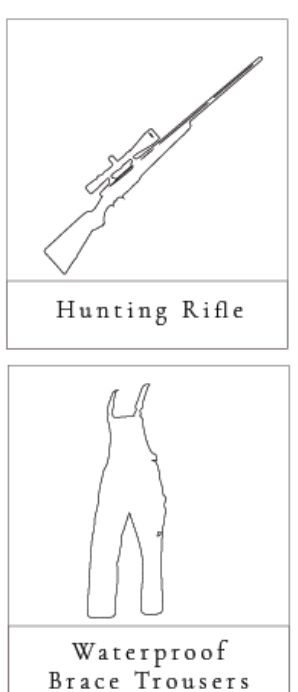
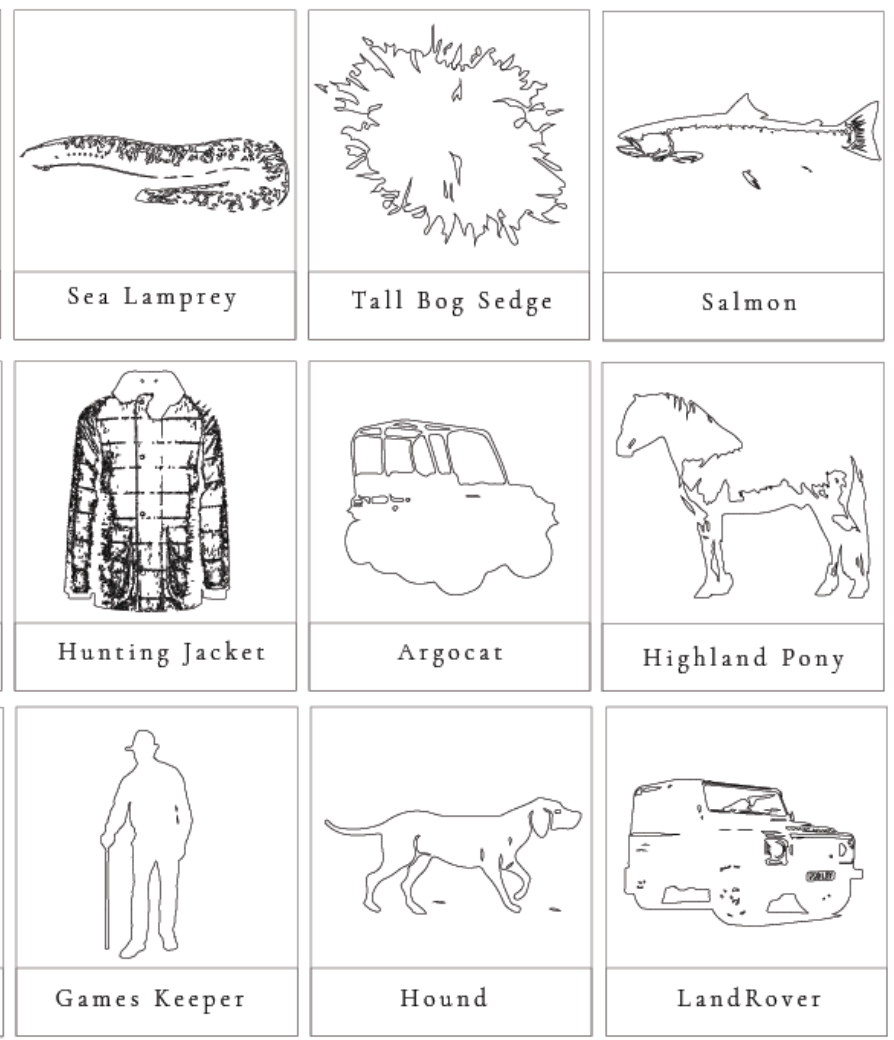
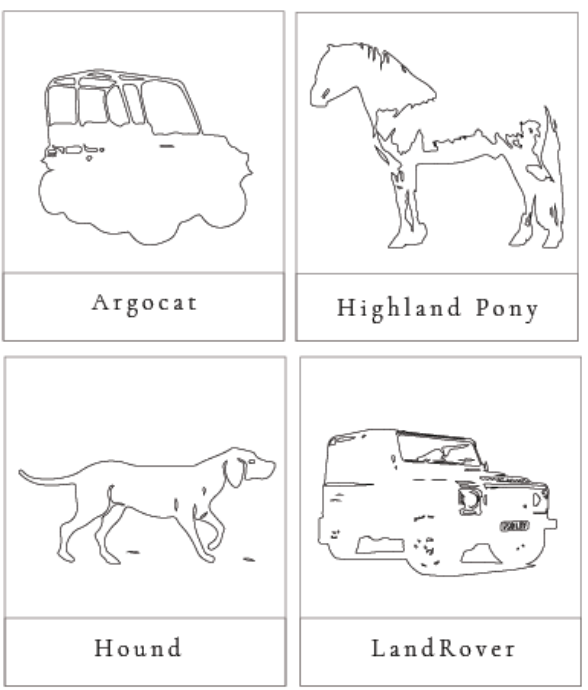

Figure 36

Rannoch Moor

Pluriverse of Relations

County : Highland

(Lochaber), Argyll and Bute,

Perth and Kinross

NATIONAL GRID

REFERENCE: NN 350520

OS 1:50,000 SHEET

NO: Landranger Series

41,42,50,51/1:25,000

SHEET NO: Explorer Series

385

AREA: 10,102.96 ha

NOTIFIED NATURAL

FEATURES:

Biological : Freshwater

habitats Dystrophic loch /

Freshwater

habitats Oligotrophic loch/

Upland habitats Blanket

bog / Birds Breeding bird

assemblage /

\section{Invertebrates Moths}

/ Invertebrates Flies

Invertebrates Beetles /

Vascular plants Vascular

plant

assemblage

Estates : Rannoch Estate \&

Black Corries Lodge

Sport Offered

Shooting - Red Grouse

Deer Stalking/Hunting - Red

Stags / Hinds

Fishing - Salmon and Brown

Trout 


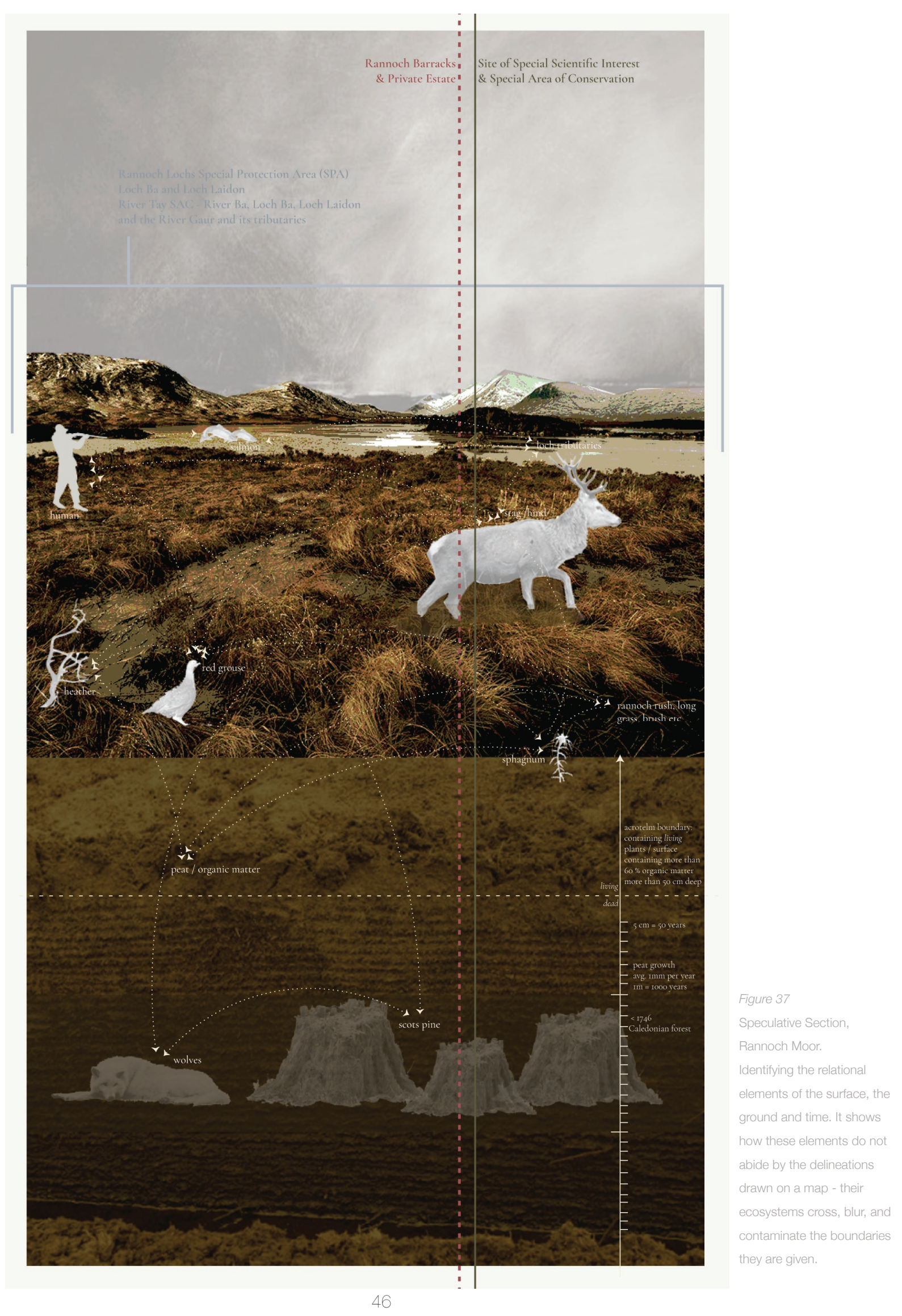


This landscape is inhabited by a range of critters, creatures, and individuals, their relationships weaving in and out of discourses of ownership, access, and ground. As such, this thesis asserts that alternative, multi species narratives must be folded into the spatial understanding of the site. How might the deer, always a pawn in considerations of wilderness management, be reconsidered in its place on the moor? New pathways emerge as attention is given to a wider, more than human demographic. How do the relationships between creatures inform an understanding of place? Ecofeminist scholar Donna Haraway explores these relationships in her work Staying with the Trouble: Making Kin in the Chthulucene. Her term "making kin" offers a way of existing that includes both human and non-human actors in a "thick present", one that acknowledges ideas of mutual endurance in which learning relies on an entwined, sticky, inventive, unfinished understanding of each other ${ }^{75}$. Relatedness carries responsibility, so a shared space or site such as Rannoch Moor needs to consider the creatures involved in order to properly speculate on an imagined, thick, future. Each creature carries consequence; the wolf becomes a symbol of manipulated 'rewilding' and the power monopoly of the landowners; the deer a national icon for wilderness sport and wide open landscapes, involuntarily taking part in a theatrical hunting performance and a key factor in the future of the sporting estate. The predator and the pray become trophies, things to be acquired or collected; manipulated futures versus mutual endurance. 


$$
\text { chapter u }
$$

The Stage

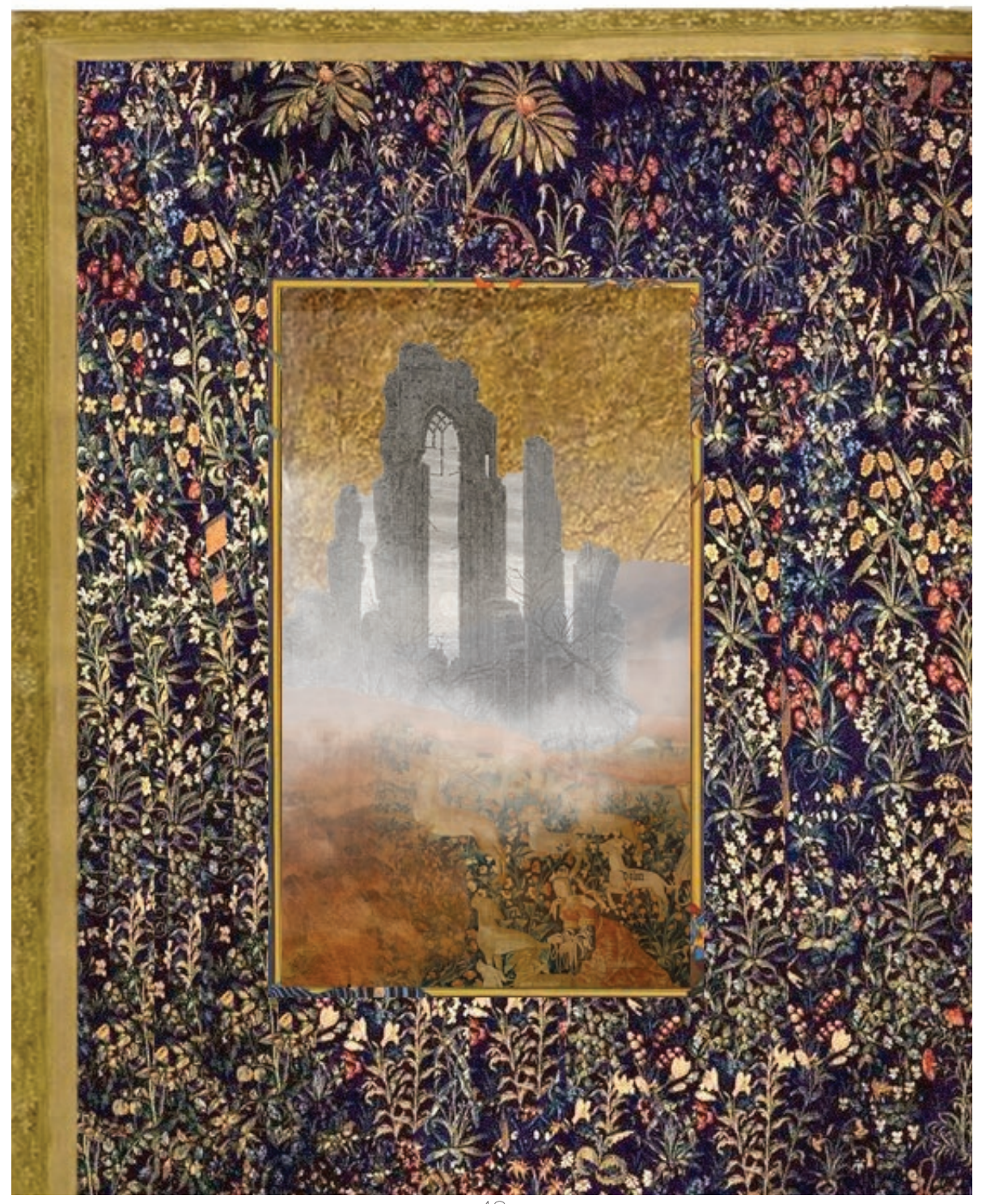

Collage Draft 
U

sing the operations, tools, and dramatis personae (outlined in Chapter I, seen in Fig. 39) that weave themselves through the history, politics and narrative of the site, new stories about space begin to take hold and are bound in layers of access, ownership, and of peat. These stories start to suggest ideas of space and place, drawing on the site's past, its present, and its atmospheres. They began to contemplate the familiar - places such as the manor house and the sporting estate. The singular estate, isolated on a vast landscape of the moor is at once a symbol of ownership, control, access, and of an imperial, cultural imposition, an analogue, in built form of the history of the landscape it sits on. Precedents were drawn, stitched and collaged from several sources. The house in Jordan Peele's Get Out learned from the idea of the sunken place as both a 0.51 metaphorical and literal prompt for a design. The estate from the Haunting of Bly Manor likewise suggested secret spaces, places of darkness and memory, where multiple narratives and times exist in a single space and place. Guillermo del Toro's manor in Crimson Peak depicts a living, sinking house that represent the collapse and decay of the social environment. A spatial analogue - in the same vein of Conan Doyle or Stevenson's descriptions of the moor - these architectural (and atmospheric) casestudies become methods of thinking through experience, narrative, story and storytelling. 
Operations

Figures

O.1 immense distances, vast, forboding

F.1 bard

5

O.2 displacing, to displace

F.2 wolf 16

0.3 vacant, empty, lonely

O.4 command, positions of power, control

0.5 extractive terrain, remove, take from

O.6 theatrical display, performace, a stage, a set

0.7 isolated, in ideas, physically, mentally

O.8 sacredness, hallowed

0.9 unstable grounds, physically and figuratively

0.10 uncertain, spaces of uncertainty

0.11 shifting terrain, shifting literally and figuratively

0.12 unsettled, unfinished, uneasy

0.13 shored up, held up, propped up

F.3 lord

F.4 tenant 16

F.5 wanderer 26

F.6 Sphagnum moss $\quad 27$

F.7 carbon 29

F.8 bog body, creatures of lore $\quad 36$

F.9 An Duine Eagalach (egg faced man) 38

F.10 Baron of Rannoch $\quad 40$

F.11 Buachaille etive mor "The Herdsman" 47

F.12 deer

O.14 facadism, to display, showcase 18

O.15 tangled, snared, bogged down in $\quad 19$

O.16 wetness, damp, wet, soggy conditions 21

0.17 changes of state, indoor to out, positions, etc. 22

0.18 bogged down, stuck, unwavering, downward 25

O.19 stage, scene, performance, spaces of drama $\quad 25$

O.20 discarded symbols, outdated spaces, historical $\quad 26$

0.21 unsure footing, unsure, speculative futures 26

0.22 wandering, movement over, in, and below grade $\quad 26$

0.23 intermediate terrain, inbetween spaces 26

0.24 thin, surreal space, uknown space $\quad 26$

O.25 unearthliness, something fantastical, revered 27

0.26 catotelm, the world of the dead, below, descent 27

O.27 maintenance, controled space, cared for space $\quad 28$

0.28 burial, confined space, small spaces, graves $\quad 29$

O.29 enveloped, surrounded, enclosed 29

O.30 underworld, below, downward, descent $\quad 29$

0.31 porous, contamination, crossover, blured $\quad 29$

O.32 imprint, mark making, memory places $\quad 29$

O.33 fragility, unknown place/space, uncertain position 30

O.34 surveying, watching, vantage point, portal $\quad 34$

O.35 hiding, hidden places, concealed 34

O.36 unseen activity, concealed, spaces of secrecy $\quad 34$

O.37 floating, held up, supported, adnit $\quad 35$

0.38 unsettled vastness, unknown, beyond seeing $\quad 35$

O.39 thickened, heaw, thick, dense, weight 35

0.40 solitude, in ideas, in position, alone $\quad 35$

O.41 footpath, pathways, tunnels, hallways 36

0.42 sentinel, watchful, height, vantage point $\quad 40$

0.43 free of trees and prominent physical markers $\quad 40$

O.44 altered perspective, to disorient, defying physics $\quad 40$

O.45 sink, to sink into, to descend, to fall, downward 42

O.46 foundations, surface engagement, stability 42

O.47 surface, surface conditions, threshold $\quad 42$

O.48 thresholds, boundaries, crossing, passage 44

O.49 envelop, encase, confined, consumed 44

O.50 manipulated, to control, manipulate $\quad 47$

O.51 sunken, sunken spaces, depth, below 49

O.52 decay, ruination, crumble, fade 49

Figure 39

Operations and Figures

The operations expanded

upon to consider the

spatial tools, movements,

and environments that

provide prompts for visual

representation. 
The following images explore and investigate the main themes of the thesis, and use collage as a type of generative spatial storytelling. The collages probe the key actors and their sets - their spaces of narrative and play - through a series of operations (spatial movements, tactics, strategies, etc) and tools (architectural, landscape, programmatic and atmospheric instruments or agents) and their relationship to the pluriverse of the moor. These collages were an attempt to reckon with the spatial implications of an expansive terrain. 

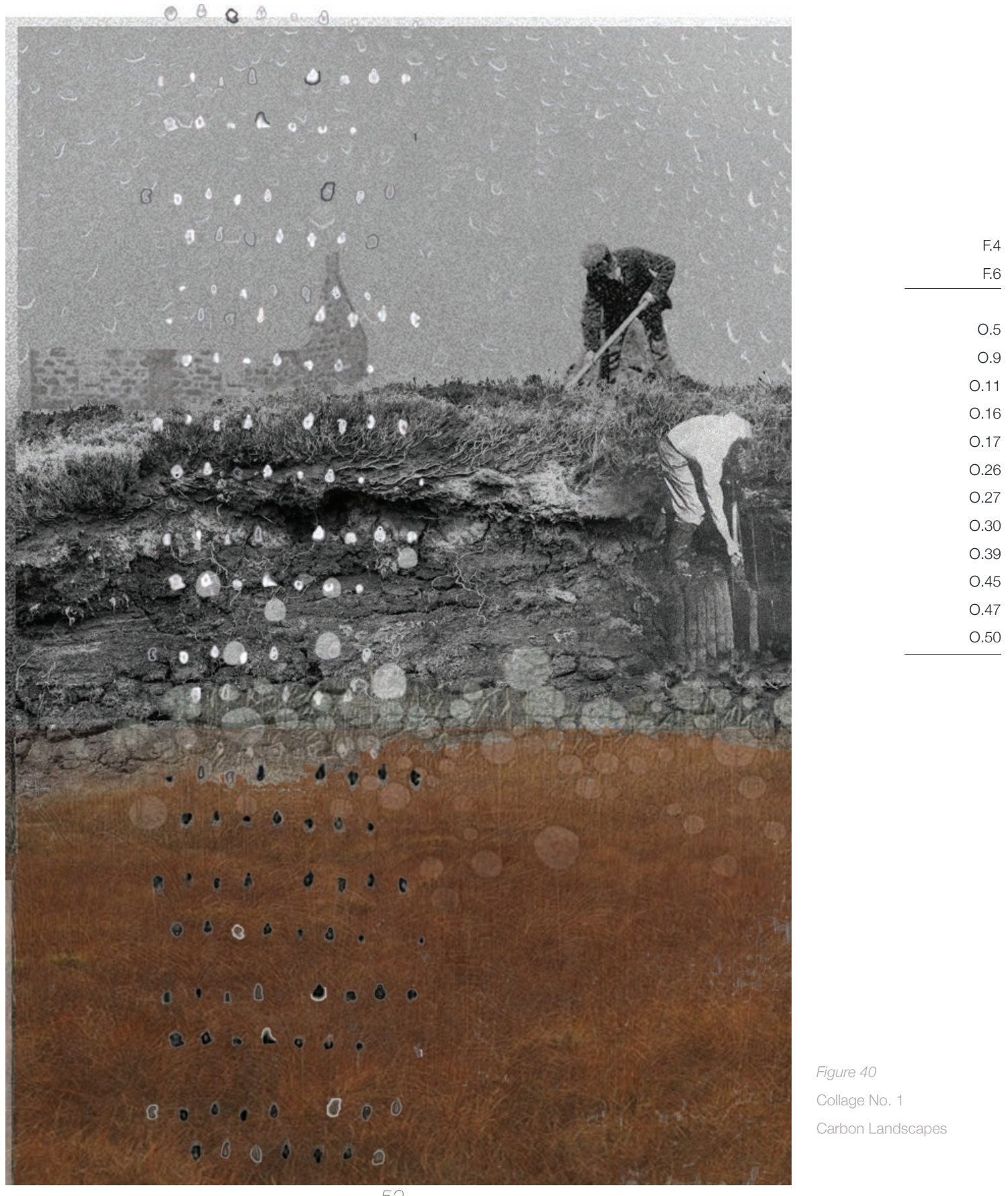

Figure 40

Collage No. 1

Carbon Landscapes 


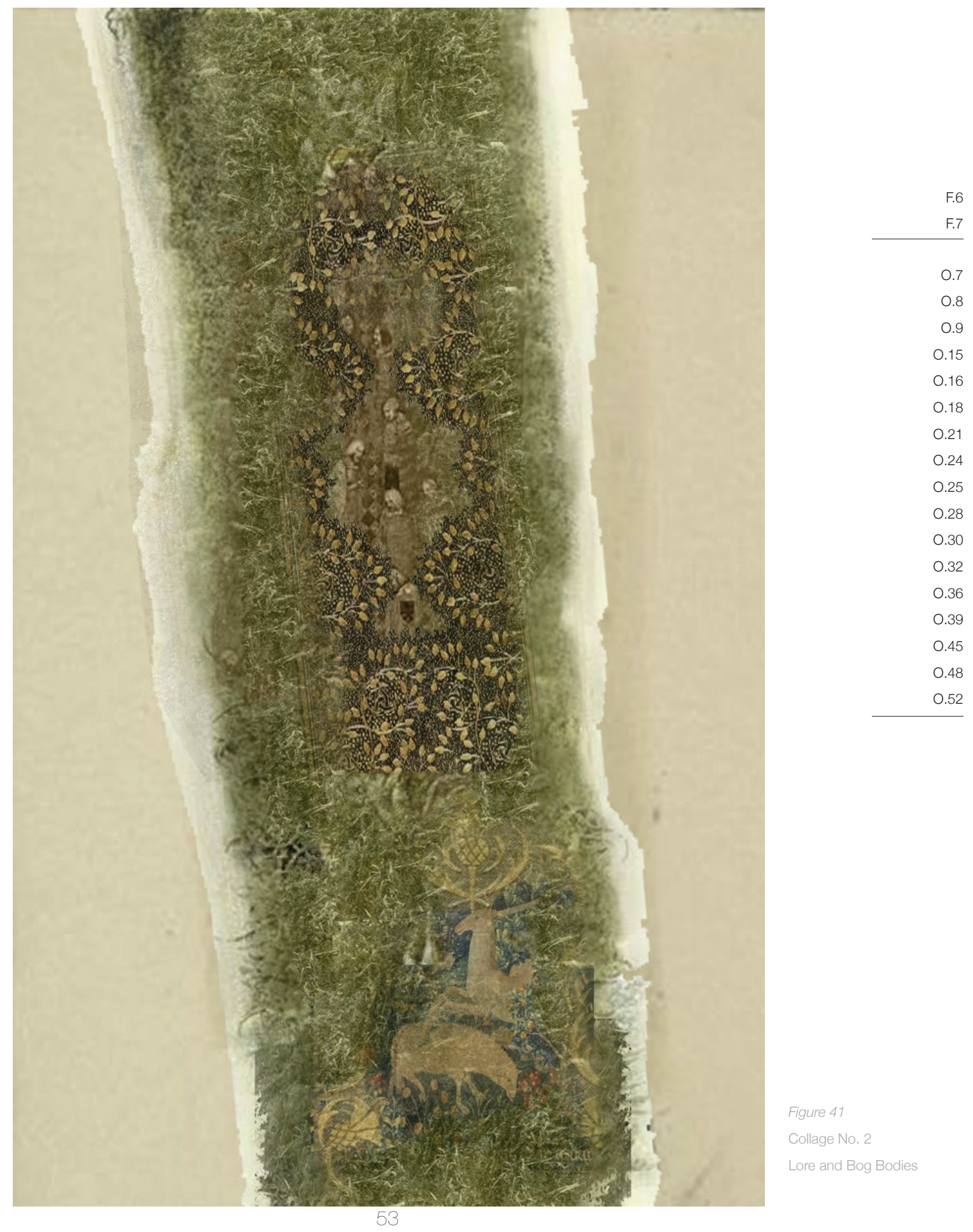




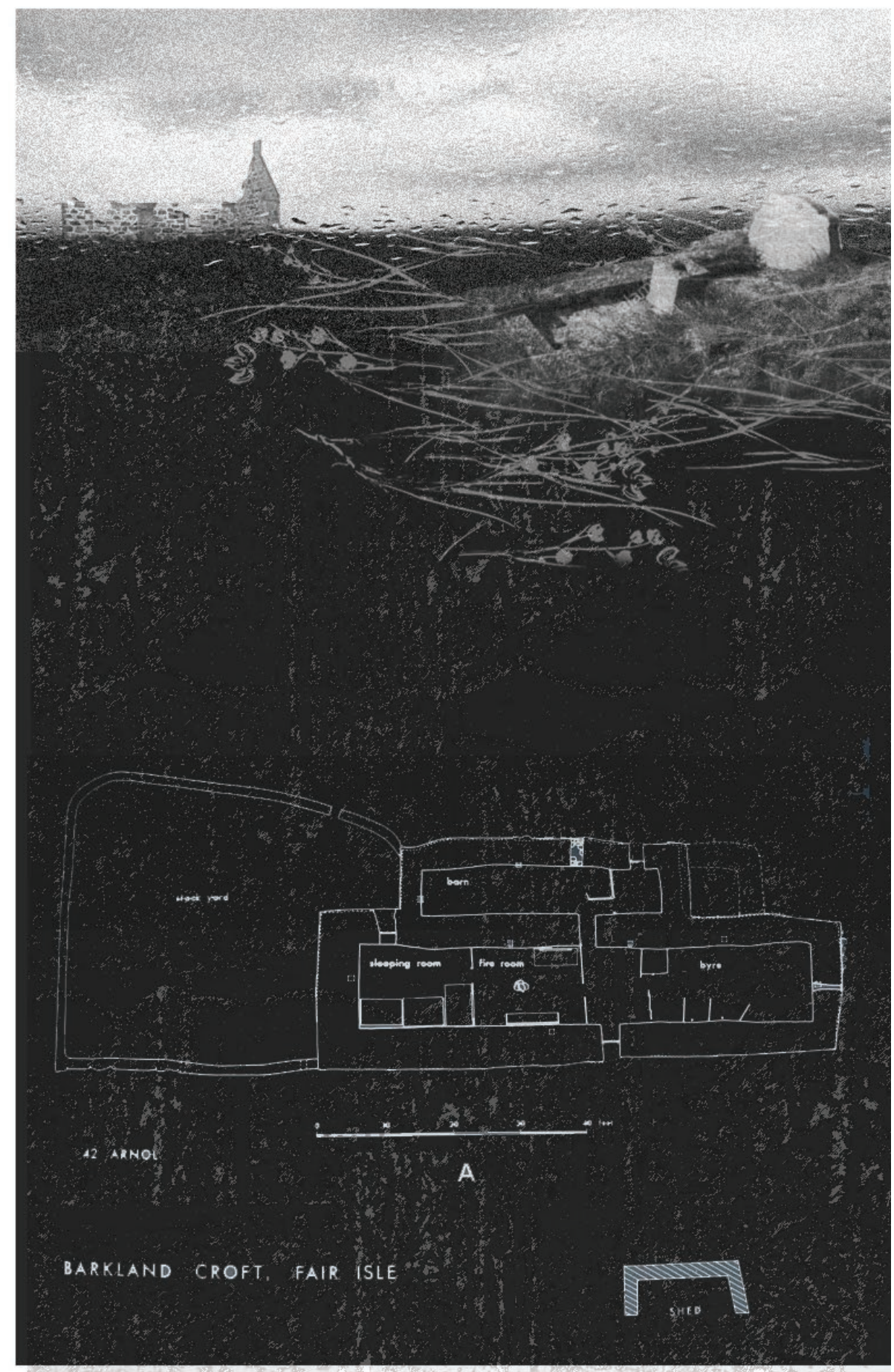

F.6

F.11

0.1

0.7

0.9

0.16

0.18

0.20

0.21

0.24

0.25

0.26

0.28

0.29

0.30

0.31

0.32

0.41

0.46

0.48

0.52

Figure 42

Collage No. 3

Sunken Foundations of

Place 


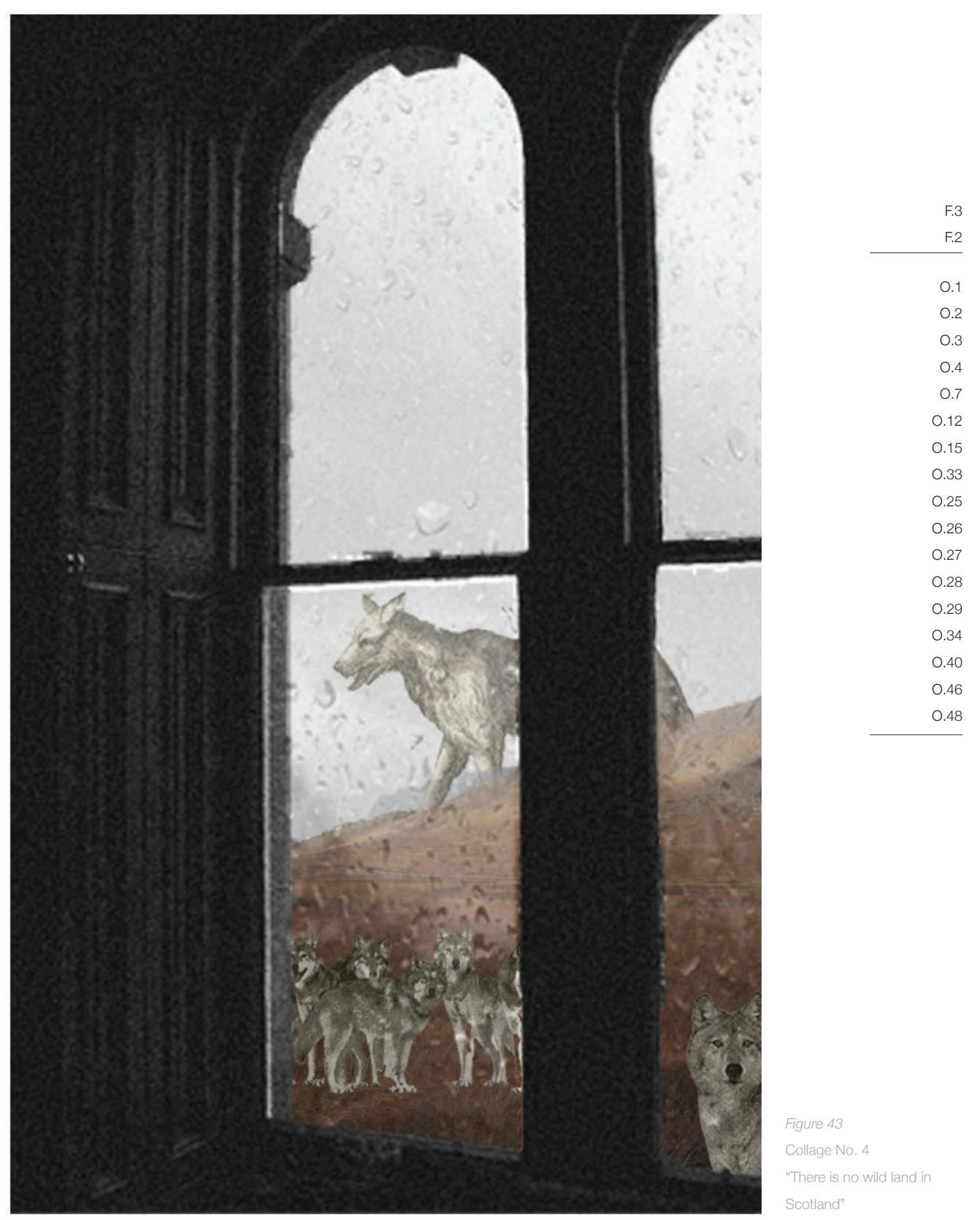




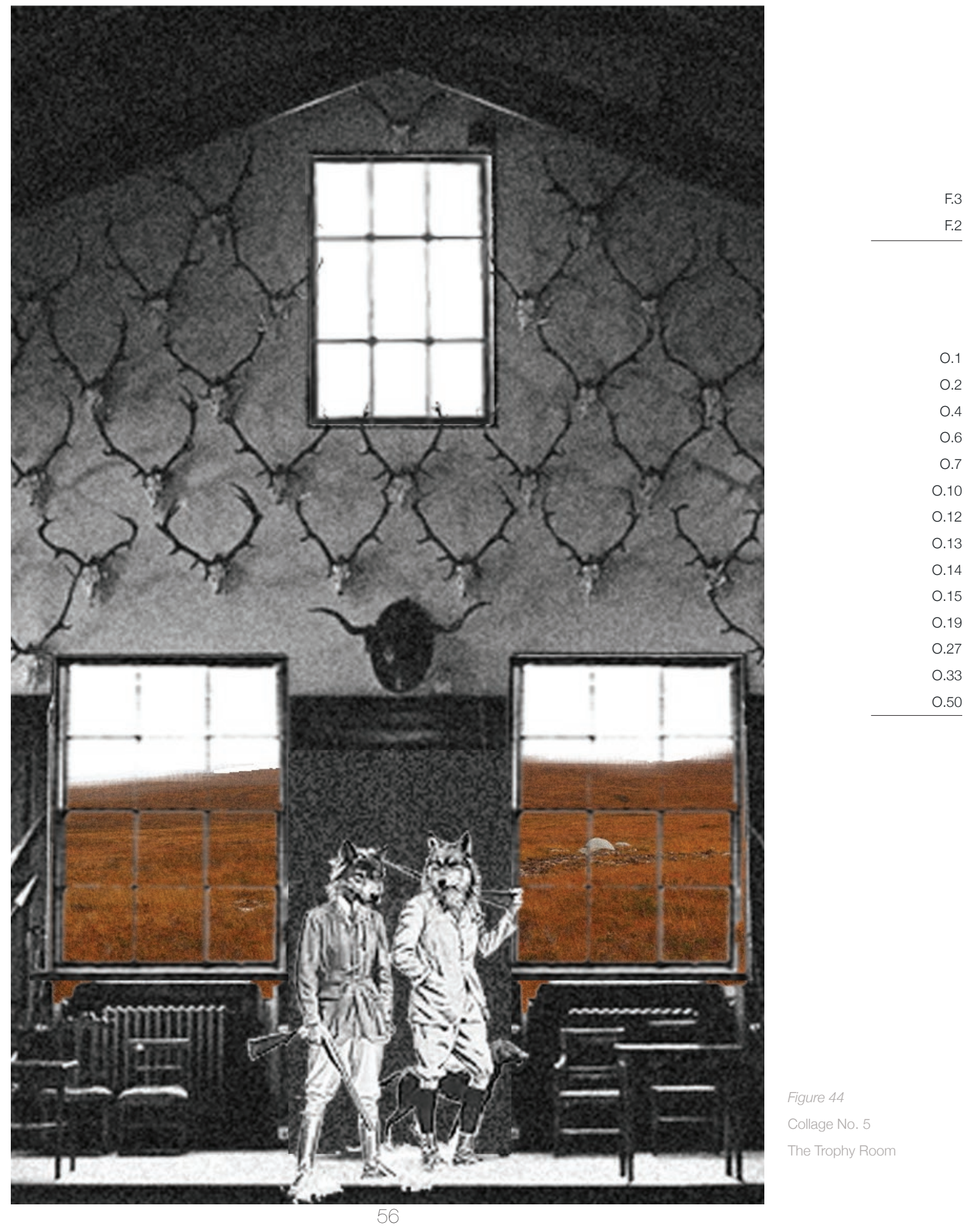




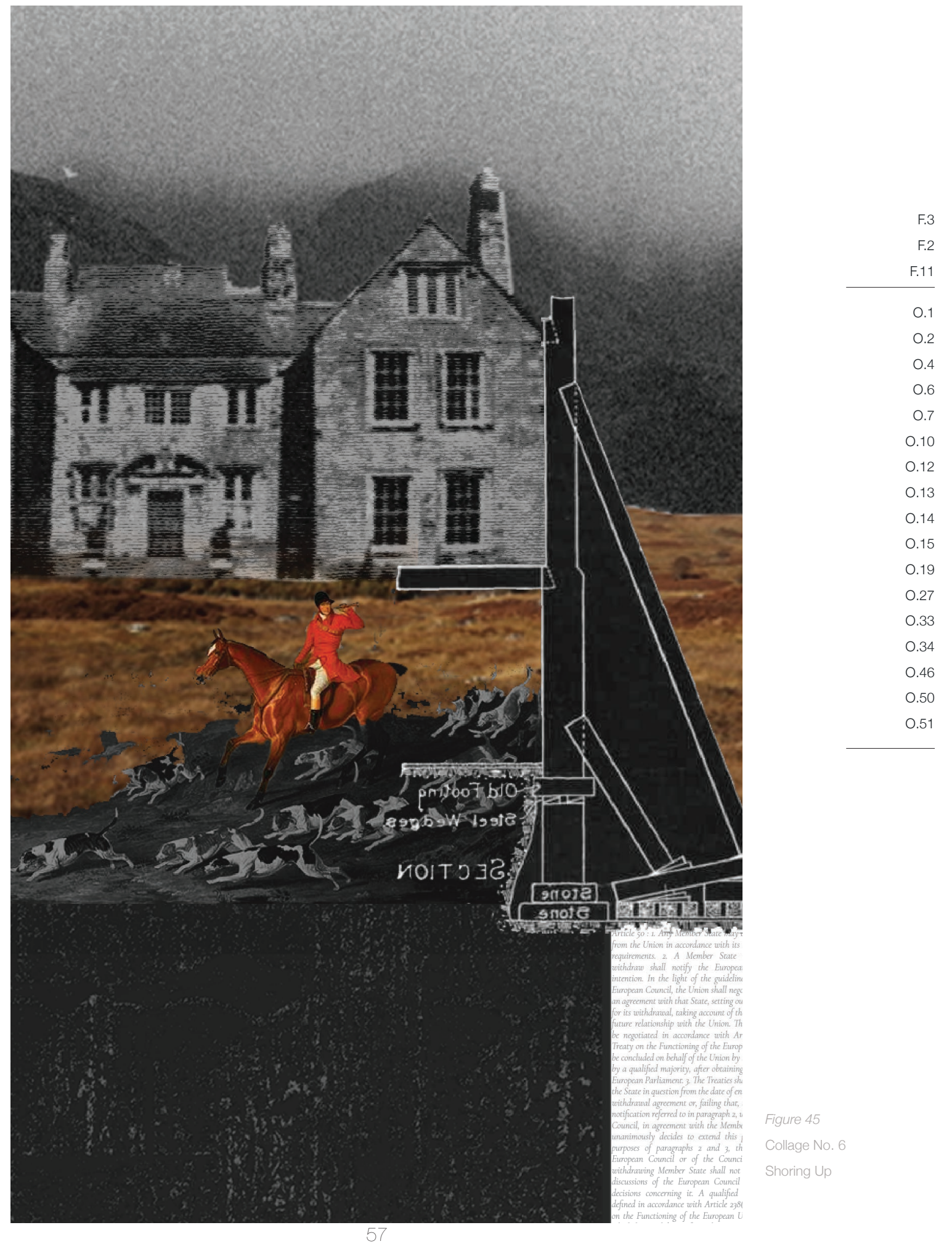




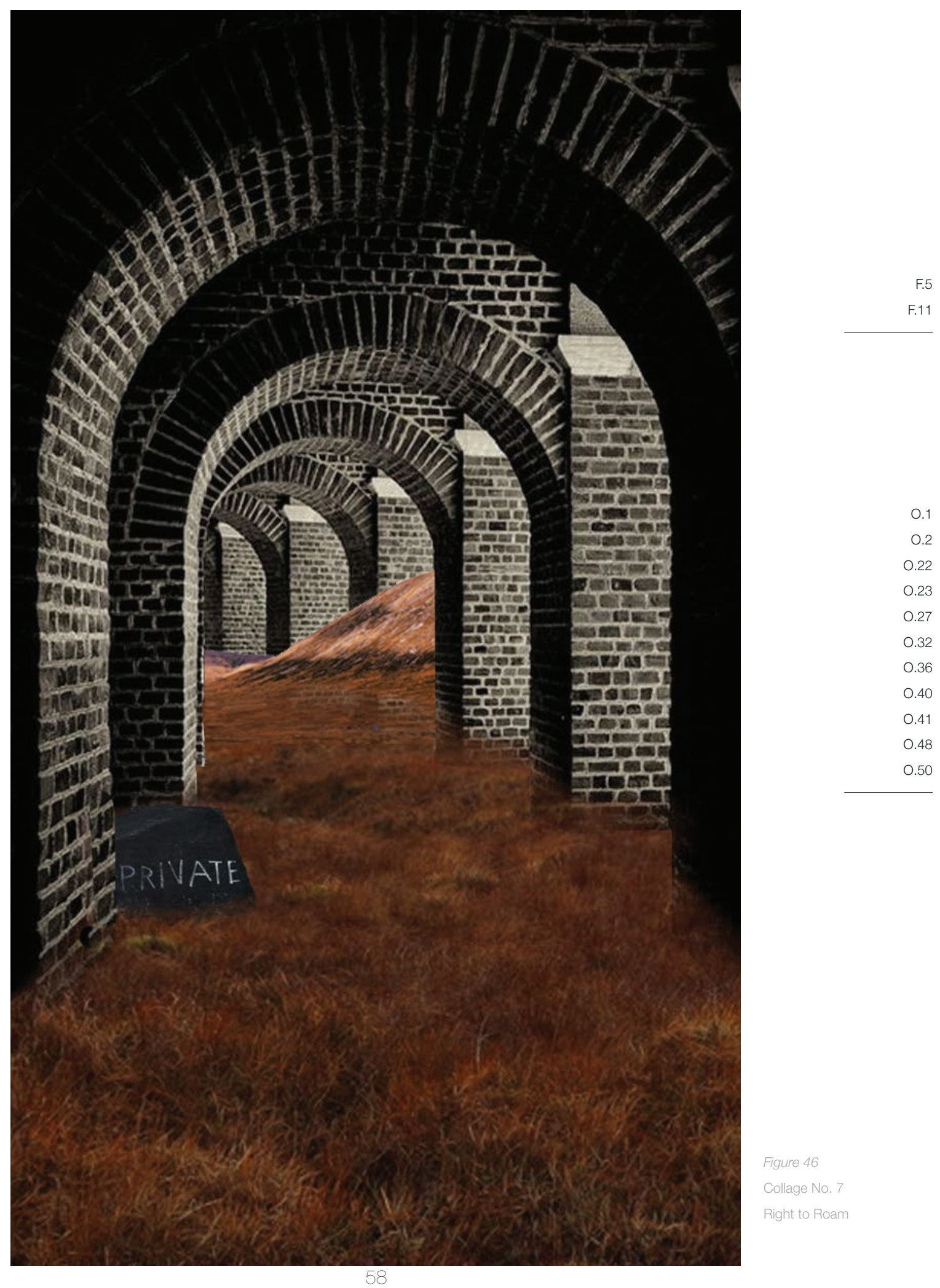




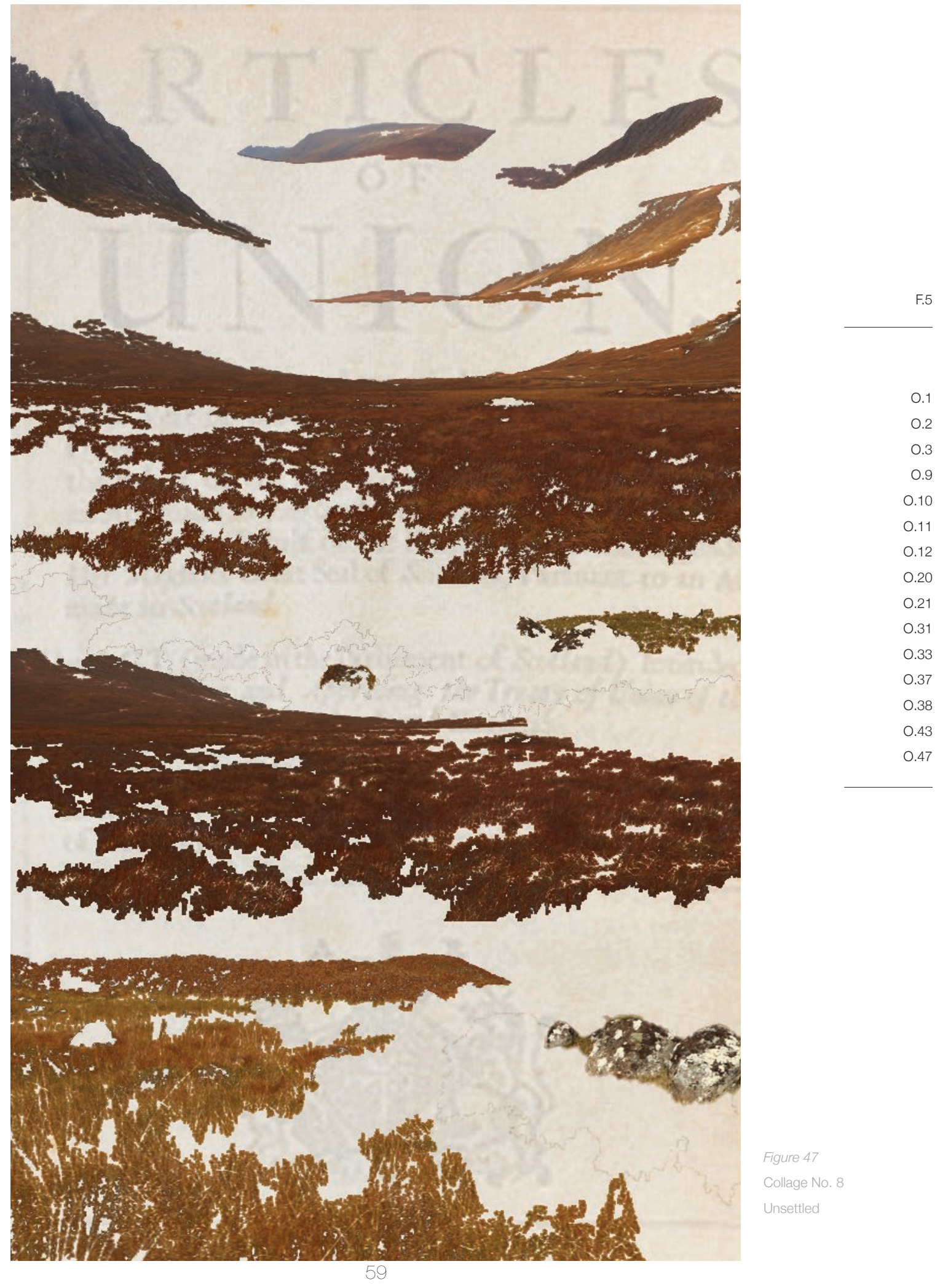




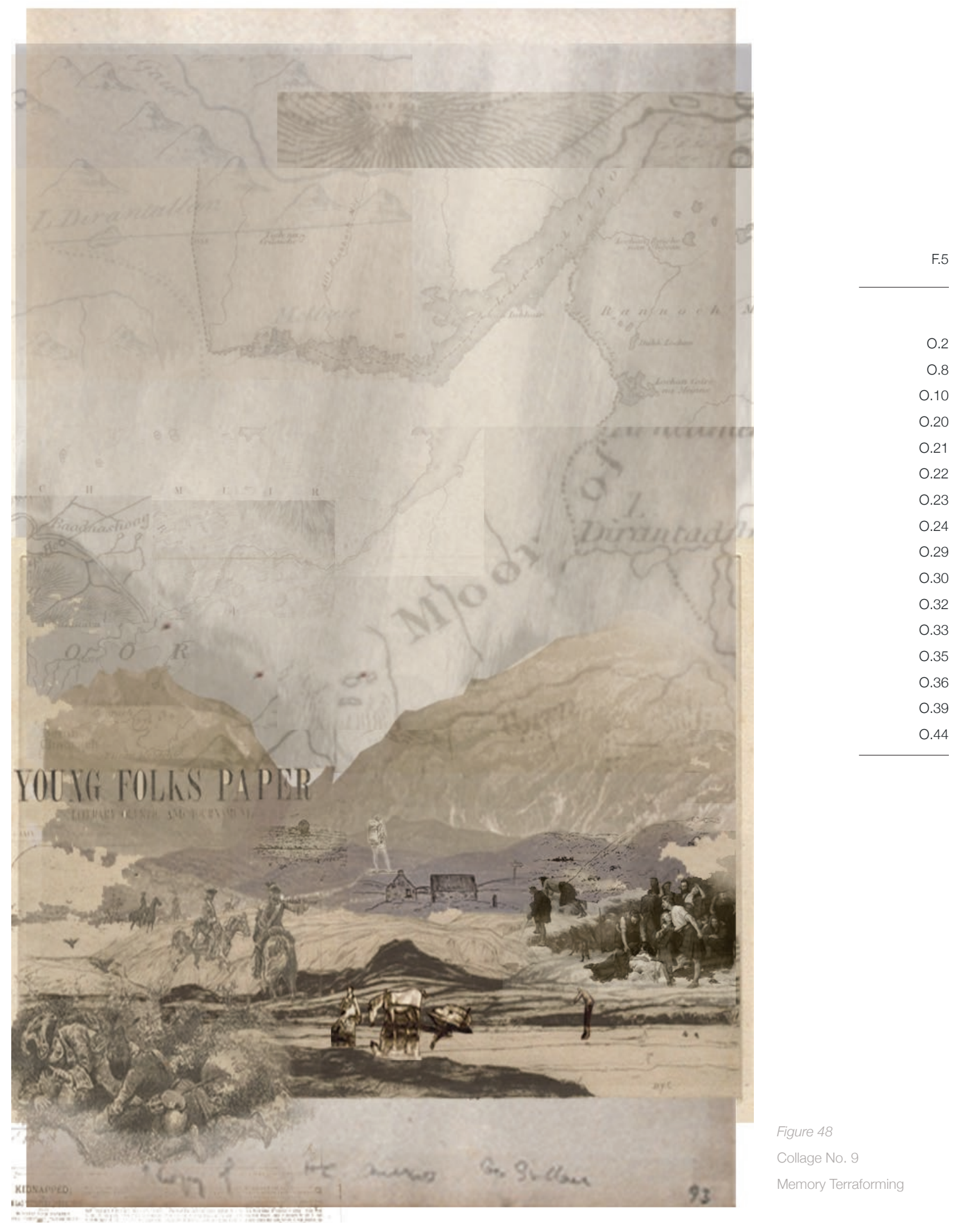


"Ideas-written ideas-are special. They are the way we transmit our stories and our thoughts from one generation to the next. If we lose them, we lose our shared history. We lose much of what makes us human. And fiction gives us empathy: it puts us inside the minds of other people, gives us the gift of seeing the world through their eyes. Fiction is a lie that tells us true things." ${ }^{6}$

-Neil Gaiman, Intro to Fahrenheit 451

Reflecting later on these collages, it occurred to me that I had returned to the space that I was exploring at the beginning of this thesis. Robert Macfarlane's way of understanding a real, lived site through history, geology, mythology and so on helps tell a more multi-faceted story, seemingly larger than life with descriptive and atmospheric moments akin to a fictional tale. Architecture, like fiction, tells a story: a story about place, about people and about the interconnectedness of space. The more I wanted to define and articulate an architectural intervention the more compelled I felt to further probe the stories that had not yet been made visible. Architecture, as a bearer of privileged meaning can suppress and stifle, as much as it can uplift and reveal. Stories, and story-telling, can be used as an agent to excavate alternative meanings about space and place that enrich an immediate architectural composition. Storytelling is a design process. As I learned more and more about the moor, about peat, carbon, Brexit, deep-time, what become increasingly evident was the capacity of storytelling to unsettle typical conventions of program, experience, space, history, time. Like the unstable ground of the moor, the thesis was becoming increasingly thick, storing multiple histories, sequestering thick interpretations, rather than carbon. The thesis peat is full of bog histories.

How can storytelling reveal un-manifested reality to be considered anew? How can we explore alternate methods of understanding a site while also thinking about how to design for a changing landscape? How does architecture describe the world? How can we design with precision - not as an act of probing for answers, for newness or novelty, but as a form of watching and waiting? Prizker Prize recipient Anne Lacaton said 
"Good architecture is open - open to life, open to enhance the freedom of anyone, where anyone can do what they need to do. It should not be demonstrative or imposing, but it must be something familiar, useful and beautiful, with the ability to quietly support the life that will take place within it."77 The 'quiet support' she talks about echoes back to the words of Angela Carter. Can we use storytelling, folklore, and myth to create a wider, richer sense of understanding? Can we use a design for waiting, for deep-time, to reflect on the values and constructions of our world as we build and adapt, and particularly, on the complex relationships that humans have with the ground and the other creatures that fly over, move on, crawl through or swim alongside these grounds. As Neil Gaiman put it: "Fiction is a lie that tells us true things ${ }^{78}$." There is an flexibility within something fictional that encourages a more limitless understanding of space and place, allowing an exploration into a series of curiosities about site and into the contact zones between the imaginary and the real.

Curiosity - An eager desire to know; inquisitiveness. Strangeness. A strange, rare, or interesting object or thing 79 .

This thesis emphasises the word 'curious' rather than the word 'interrogative,' openness, rather than solutionism. Initially I looked for problems to solve: with the ground, with the climate, with property ownership, by trying to understand the layers of a landscape. As the work progressed, it was reframed rather, to consider how we think about problem solving, solutions, and the value of this pursuit. Rob Holmes, a professor of landscape architecture at Auburn University, reflects on this process in his text "The Problem with Solutions." He writes:

"Landscapes everywhere are shaped by complex, asymmetric power relations at different densities and scales. Everything about them is dynamic - forms, structures, cycles, trajectories - and all of it subject to natural and anthropogenic forces that frustrate human desires for stability and control. What appears to be a problem from one angle may be desirable from another, and vice versa. Designers have always understood these truths, on some level, but that hasn't stopped us from endeavoring to solve landscapes, over and over."

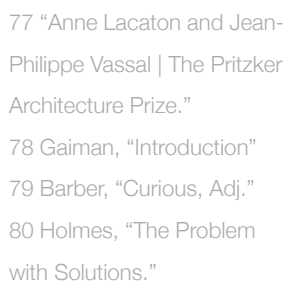


I learned that the exactness or stability I was trying to find had eluded me; the ground of the moor is too wet, too unstable, too liquid. This realization encouraged me to look at space differently; to pursue a series of curiosities that offered a more open ended approach that could acknowledge the plural vitalities of a site.

These curiosities became a set of stories that attempt to understand the moor and its strangeness, its unusualness, its unconventional-ness, its unknown-ness. This peaty imagination was a way to look at how complex things and stories become communicative aids that help us to speculative on the agency of architectural imagination as a way to know and think through - and see the possibilities of - a changing landscape.

\section{V.III The Reflection} ... multispecies storytelling is about recuperation in complex histories that are as full of dying as living, as full of endings, even genocides, as beginnings. ${ }^{81}$

- Donna Haraway, Staying with the Trouble

Haraway tells us that stories contain deep times and deep relations. They hold layered histories and narratives of the past, present and future that are all bound together. This storytelling suggests a movement to look not to the past, or to the future, but to the deepness of the conditions that surround us, weaving together a more complex tapestry towards recuperation and resilience. Amitav Ghosh says that fiction makes possible the imagining of possibilities. ${ }^{{ }^{2}}$ Architecture needs storytelling as a multiverse method of worldbuilding, beyond schematic design drawings, construction document sets or shiny buildings. Stories have the opportunity to shift or widen how architects think about the world and how they work in the world, helping reorient ideas of the discipline. Every proposal of unbuilt work is technically a story of some sort - a fiction based on various input, reflected in a proposed physical form. Until the work is physically realized it remains a fiction. Embracing the notion of storytelling allows the fictional element to stand on its own, not purely as a connection to the empirical. Architecture has the capacity to tell stories through its natural connection to worldbuilding, integrating sources it had not previously considered and representation styles that play to the fantastical elements of space. Worldbuilding considers the future using a much wider lens than

81 Haraway, Staying with the Trouble, 9 . 82 Ghosh, The Great Derangement. 
is traditionally understood in architectural pedagogy, or in conventional practice. Returning back to the example of the Onkalo nuclear waste site in Finland - in which folklore is used to contemplate the nature of buried nuclear waste - the Kalevala tells of the underland, the storage of dangerous materials and warning signs to those that attempt to unearth them $^{8}$. Architecture merges with ancient lore, offering eerie connections to worlds of the past and transcending to future terrains. The Storage Room in New Mexico is another nuclear waste burial site, which in its realization, drew on the assistance of science fiction writers to help imagine an intervention that will be able to warn people far into the future of the dangerous nature of the ground underneath their feet.

"We are going to tell you what lies underground, why you should
not disturb this place, and what may happen if you do.
This site was known as the WIPP (Waste Isolaation Pilot Plant
Site_when it was closed in $2038 A D$.
The waste was generated during the manufacture of nuclear
weapons, also called atomic bombs.
We believe that we have an obligation to protect future generations
from the hazards that we have created. This message is a warning
about danger. We urge you to keep the room intact and buried." ${ }_{4}^{4}$

This thesis proposes a series of fictional narratives, told through the characters and spatial operations highlighted in the previous chapters. The stories are interwoven, to be realized as a whole story that uses a nonlinear timeframe to explore the dynamics of the landscape of Rannoch Moor, through interrelated, but diverging histories. The varied sources that have informed the research provide a pluralistic view for the tales, proposing alternative ways of knowing. They will speculate on the future of Rannoch Moor using characters such as the land owner, the bog person, the crofter, as well as employing a multi species approach with a story told through the eyes of a deer. They will track, trace, and upend - through thick and thin - notions of geological time, history, literature and lore through a speculative imaginary of Rannoch Moor. 
chapter in

The Narrative

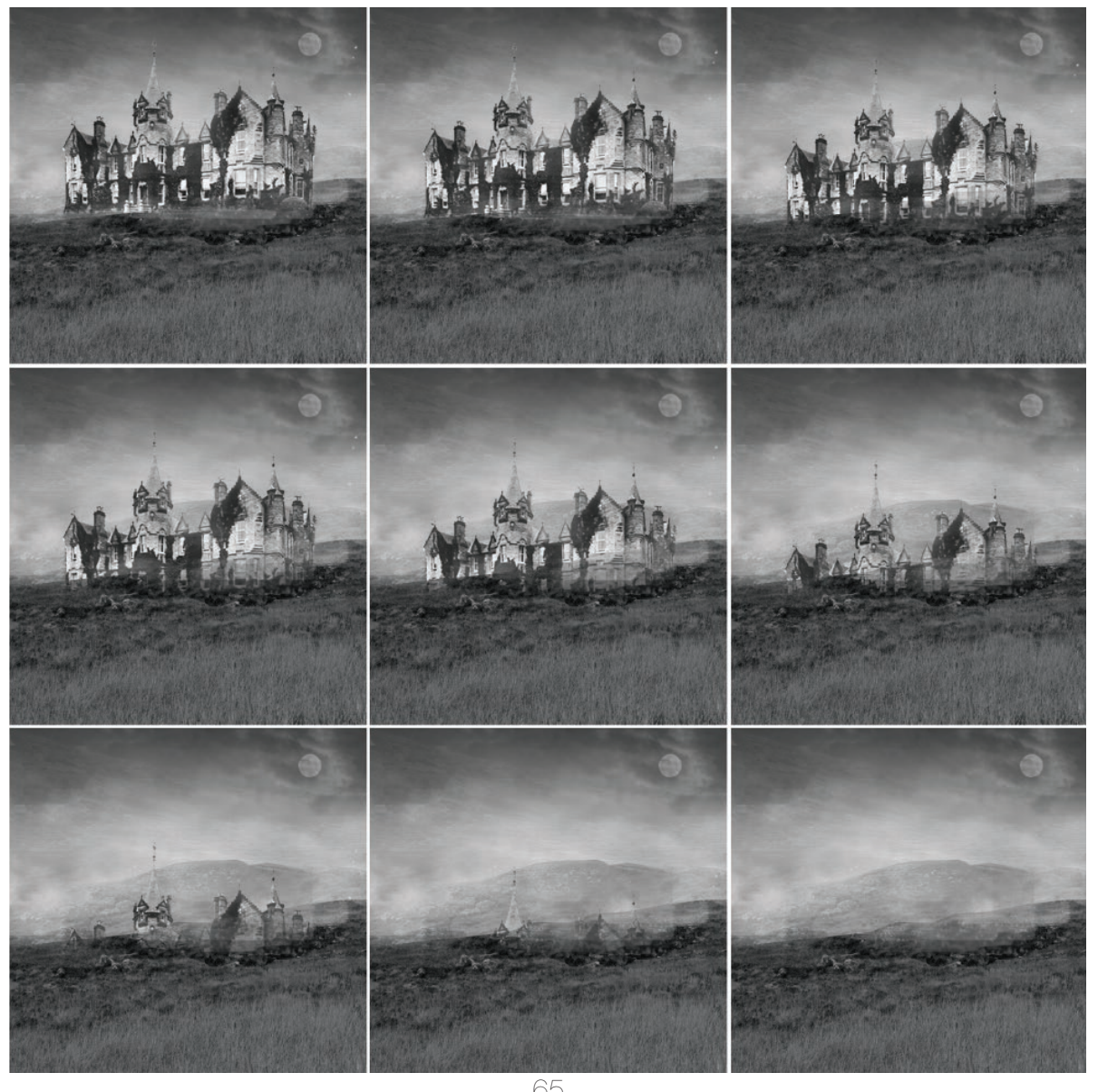

Figure 49

Sunken House 
he tale is a product of taking apart, putting together, twisting,
unfolding, and folding the spatial operations, tools and figures
of this thesis. They employ obscured timeframe in which pasts, presents, and futures melt into each other in the Moor and the House. As mentioned in previous chapters the manor house symbolizes some of the inequitable relationships of the Scottish landscape. It is an almost foreign entity on the moor, a weighty stone structure that imposes itself onto the unstable terrain, importing a particular way of living and of construction with far reaching effects on land management and controls. It is a house that contains ideas, accolades, and artifacts of the past, sitting alone in a vast landscape. The narrative is bound within the Moor and the House, tracing the stories through their origins and destinations, using an obscured time frame to explore the various operations, tools and characters that have been woven through the research. Scholar Kate Bernheimer notes: "Houses in fairy tales are never just houses; they always contain secrets and dreams... [they] presents a new path of inquiry, a new line of flight into architecture as a fantastic, literary realm of becoming." 85 The story follows these paths of inquiry into the dynamic landscape of the moor.

The story is accompanied by a set of collage that explore the spatial conditions of site, employing architectural details, material conditions, literary refernce, discarded symbols, and a register that reflects on the props, items, figures and operations that lend themselves to the narrative 85 Bernheimer, Bernheimer, "Fairy Tale Architecture." experience (Figure 50). 
0.1 immense distances, vast, forboding

0.2 displacing, to displace

0.3 vacant, empty, lonely

O.4 command, positions of power, control

O.5 extractive terrain, remove, take from

O.6 theatrical display, performace, a stage, a set

0.7 isolated, in ideas, physically, mentally

0.8 sacredness, hallowed

0.9 unstable grounds, physically and figuratively

0.10 uncertain, spaces of uncertainty

0.11 shifting terrain, shifting literally and figuratively

0.12 unsettled, unfinished, uneasy

0.13 shored up, held up, propped up

0.14 facadism, to display, showcase

0.15 tangled, snared, bogged down in

0.16 wetness, damp, wet, soggy conditions

0.17 changes of state, indoor to out, positions, etc.

0.18 bogged down, stuck, unwavering, downward

0.19 stage, scene, performance, spaces of drama

0.20 discarded symbols, outdated spaces, historical

0.21 unsure footing, unsure, speculative futures

0.22 wandering, movement over, in, and below grade

0.23 intermediate terrain, inbetween spaces

O.24 thin, surreal space, uknown space

O.25 unearthliness, something fantastical, revered

0.26 catotelm, the world of the dead, below, descent

0.27 maintenance, controled space, cared for space

0.28 burial, confined space, small spaces, graves

0.29 enveloped, surrounded, enclosed

O.30 underworld, below, downward, descent

0.31 porous, contamination, crossover, blurred

O.32 imprint, mark making, memory places

O.33 fragility, unknown place/space, uncertain position

0.34 surveying, watching, vantage point, portal

0.35 hiding, hidden places, concealed

O.36 unseen activity, concealed, spaces of secrecy

0.37 floating, held up, supported, adrift

0.38 unsettled vastness, unknown, beyond seeing

O.39 thickened, heavy, thick, dense, weight

$\mathrm{O} .40$ solitude, in ideas, in position, alone

0.41 footpath, pathways, tunnels, hallways

O.42 sentinel, watchful, height, vantage point

0.43 free of trees and prominent physical markers

0.44 altered perspective, to disorient, defying physics

0.45 sink, to sink into, to descend, to fall, downward

0.46 foundations, surface engagement, stability

0.47 surface, surface conditions, threshold

0.48 thresholds, boundaries, crossing, passage

O.49 envelop, encase, confined, consumed

O.50 manipulated, to control, manipulate

0.51 sunken, sunken spaces, depth, below

0.52 decay, ruination, crumble, fade
F.2 wolf

F.3 lord / landowner/ figures of sovereignty

F.4 tenant

F.5 wanderer / The Stravaig

F.6 Sphagnum moss

F.7 carbon / The Moor

F.8 bog body, creatures of lore

F.9 An Duine Eagalach (egg faced man)

F.10 Baron of Rannoch

F.11 Buachaille etive mor "The Herdsman"

F.12 deer / The Hart

F.13 The Raven

Program/Places

P.1 The Landscape

P.2 Entrance Happ

P.3 Passageway

P.4 Drawing Room

P.5 Catotelm

Items $\quad$ I.1 Door

1.2 Peat

I.3 Tapestry

I.4 Square Rubble

I.5 Chaise Lounge

1.6 Wardrobe

I.7 French Crystal Lamp

1.8 Fauteuil Chair

1.9 Grandfather Clock

I.10 Rosewood Centre Table Dining

I.11 Chippendale Writing Desk

I.11 Savonarola

I.12 Harling

I.13 Coffer

I.14 Oak Panelling

I. 15 Rannoch Moor Map

I.16 Duke of Sutherland Portrait

I.17 Taxidermy Grouse

I.18 Carved Oak Victorian Hall Table

I.19 Persian Hall Runner

I.20 Taxidermy Hart

I.21 Marble Mantle

1.22 Book of Deer

1.23 Land Reform Act

1.24 Window

1.25 Gothic Chair

I.26 Estate Register

1.27 Black Watch Rug

I.28 Stone Masonry

I.29 Brushwood

1.30 Ashlar Dressings

I.31 Veiled Curtain

I.32 Gravestones

Figure 50

1.33 Strata 
This is a Story of The Moor, The House, The Moss,

The Stravaig, The Baron, The Body, and The Hart

read by Kirsten Nicholson 
The Moor

A non-human actor, a force of deep time.

The House

The core, the character of reflection, the mirror. From monument to ruination.

\section{The Moss}

A key agent of the moor.

The Stravaig

Scottish word for wander, often aimless. The wanderer. Unnamed, unidentified figure that traverses The Moor and The House and facilitates the dialog between the characters in his movements.

\section{The Baron}

The landowner, consumed with old ideas of possession and ownership, confined to The House as penance.

\section{The Body}

The bog body, inhabiting the world below the ground living in peaty confines.

The Hart

Adult male deer or stag. A symbol of the desired, of wanted possession and manipulation. 


\title{
The Moor
}

I am the beginning and the end; the veil; the shadows.

The House

\begin{abstract}
"The mansion-house occupies a commanding and beautiful situation, overlooking the richly grounds of Rannoch [Moor], famed for its salubrity of climate and for its charming and romantic scenery. It is a good specimen of the Scottish Baronial style of Architecture. The House faces the south and is sheltered by tree plantations to the east. The views from the windows embrace [Rannoch Moor] and the Glencoe Mountains.
\end{abstract}

The House is furnished with every comfort and convenience, and has been recently improved, painted, and decorated at very great cost. It contains accommodation for a large establishment and the Rooms are large, lofty, and well arranged. There is a spacious Entrance Hall, and there is also an Inner Corridor over sixty feet in length - all beautifully decorated. The Drawing Rooms occupy the south east angle of the House and command magnificent views.

The shootings are among the best and most extensive in Scotland. Last season they yielded about 3400 Brace of Grouse besides large bags of other game, including pheasants, partridges, wild-fowl, roe deer, and brown hares \&C." 86

The Stravaig

The Stravaig, lost, wanders over The Moor.

A thick fog rolls across the boggy terrain. The last rays of daylight linger on the landscape before flickering out, throwing the Stravaig, and the world around 86 Estate Exchanges, "Estate Exchange, No. 1518 him into darkness. Uneasiness creeps across the heather and under the skin. 


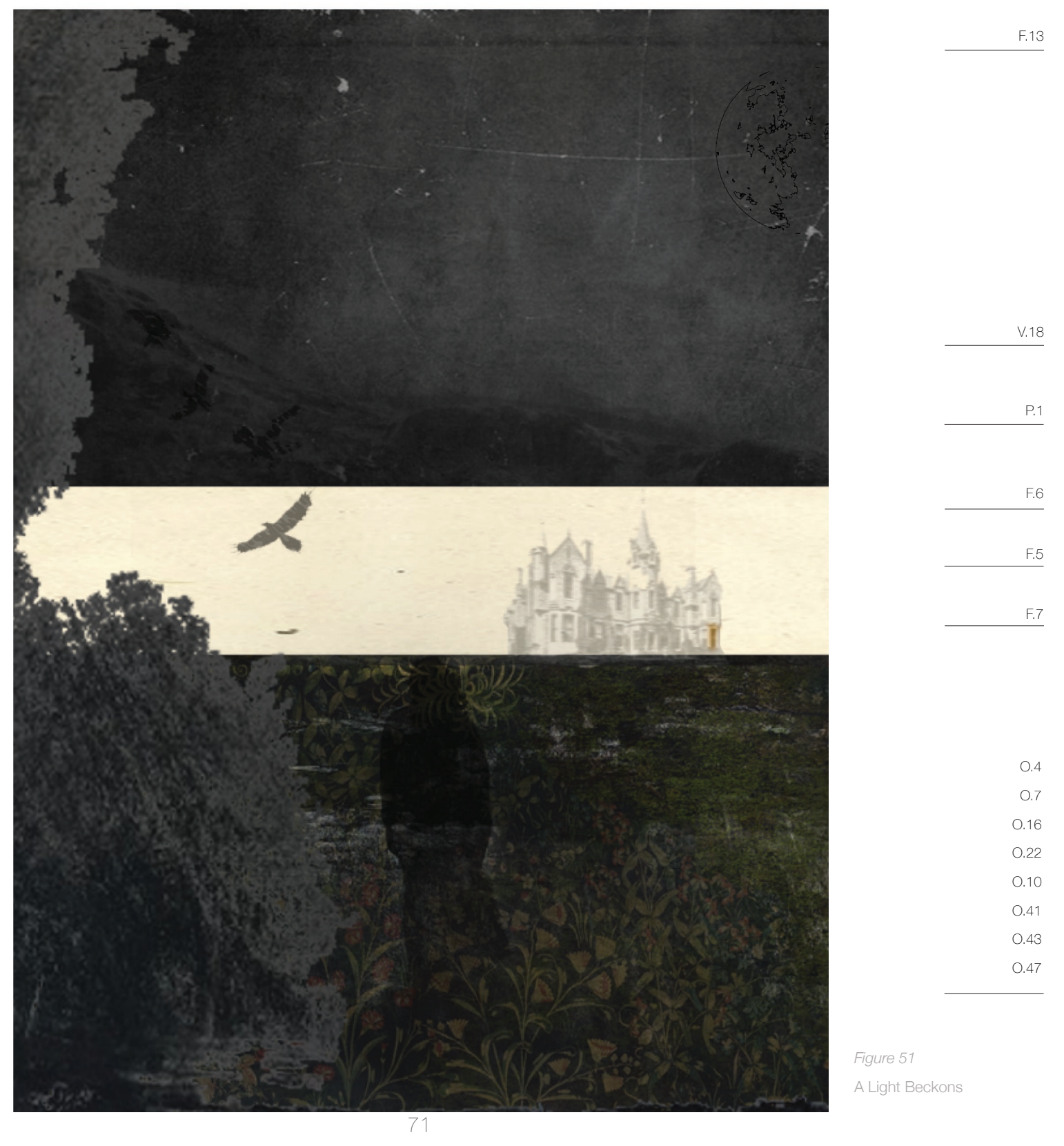


Something watches; he can feel it. The fog curls and eddies like wisps of smoke, or oil in a stream. His steps sink, deeper into the ground with each fumbling step as he struggles to find the footpath. A low wolf howl rises up behind him.

A faint light flickers in the distance, beckoning further into The Moor. The Stravaig moves toward it and a lone structure looms out of the fog, a vestige of the old world, a building half buried in the moor's peaty earth. The Stravaig approaches, and the house door retreats. He moves fast, forward. The door recoils, matching his speed. The land here dissembles, grifts. The Moor is a trickster.

Suddenly, unexpectedly, he is through the door falling downwards into the House. Down through the porous ground. Past the layers of chicken bones and plastic. Past the retreating glaciers. Down. 


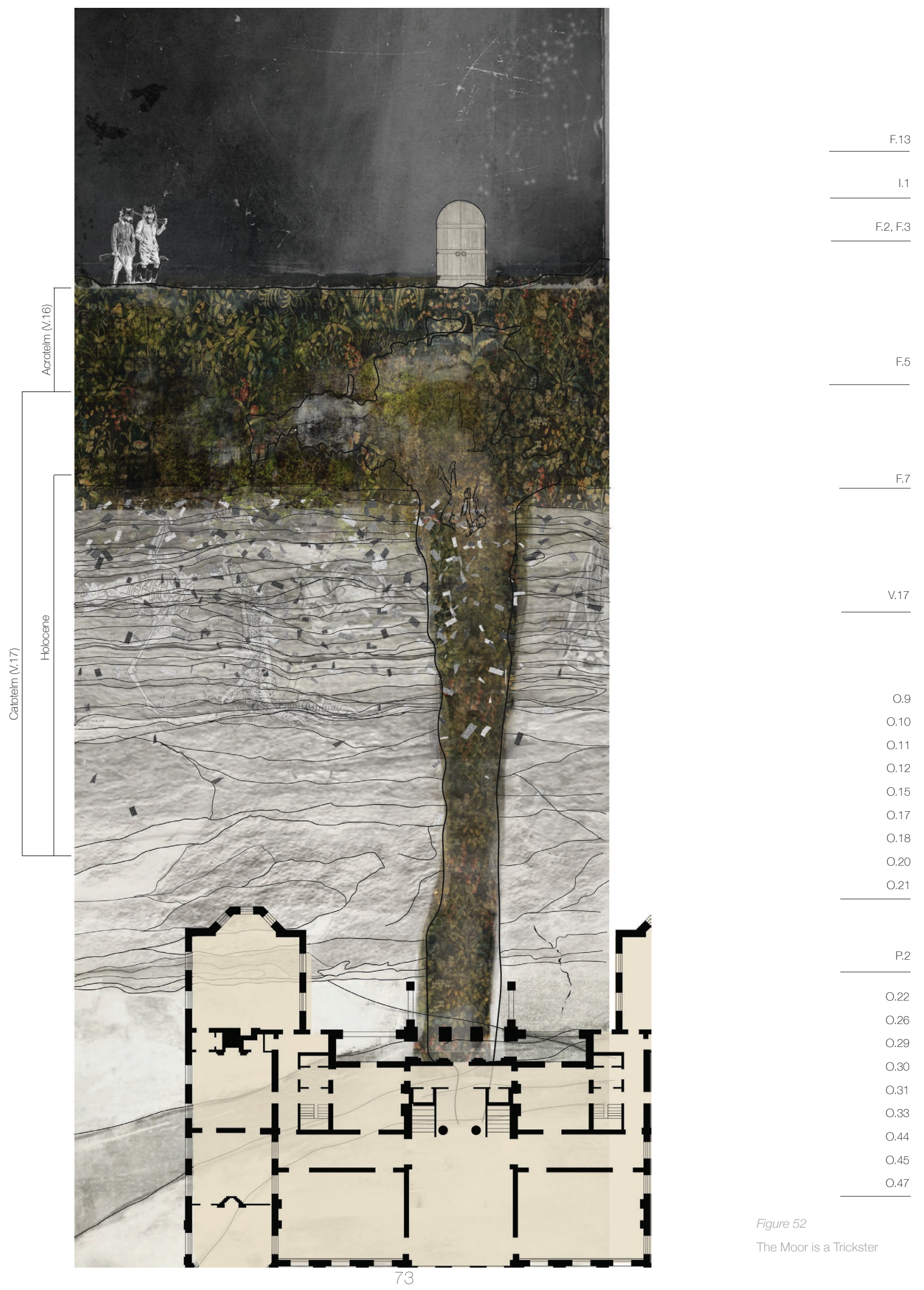


The House

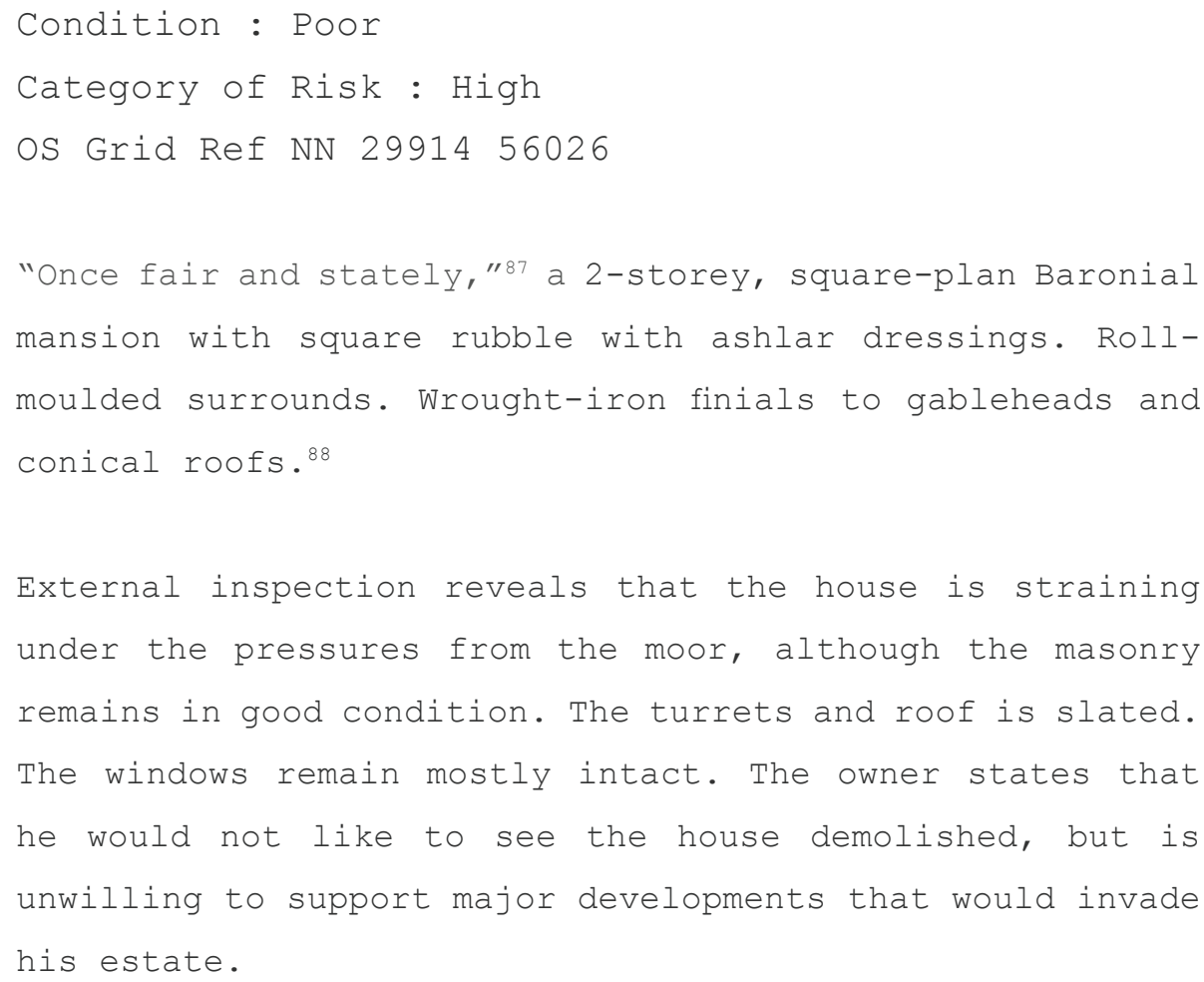

The Moss

The fiercest agent; holder of water, storer of carbon, tomorrow's peat.

The Stravaig

The Entrance Hall of the old baronial estate appears, the walls lined with elaborate furnishings stacked upon one another, leaning against the wall as if keeping something out, barricading against unknown forces. He notices damp, mossy intruders, the smell of the peaty catotelm breathing through the wall. The 
grandfather clocks, Chippendale writing desks, candelabras, tapestries and art are propped up in a seemingly rearguard action against the swell of the Moor. He can almost hear the timber straining along the ceiling, an aging, arthritic Atlas against the forces from the other side. He notices a large crack running through the stones.

He hears footsteps approach him, from the shadows. Suddenly, shockingly, a tall, slender grey man strides up to him, and passes without a word. The Stravaig froze with horror. The man had a grotesque egg shaped head and no face, all of his features had faded away.

The Moor

89 Flanagan, "The Romance

of Certain Old Clothes."

50:08.

Time takes all things. Flesh, stone, even stars themselves. Tis the way of the world...

The past recedes, memories fade, and so too does [The House]. Everything yields to time. ${ }^{89}$ 

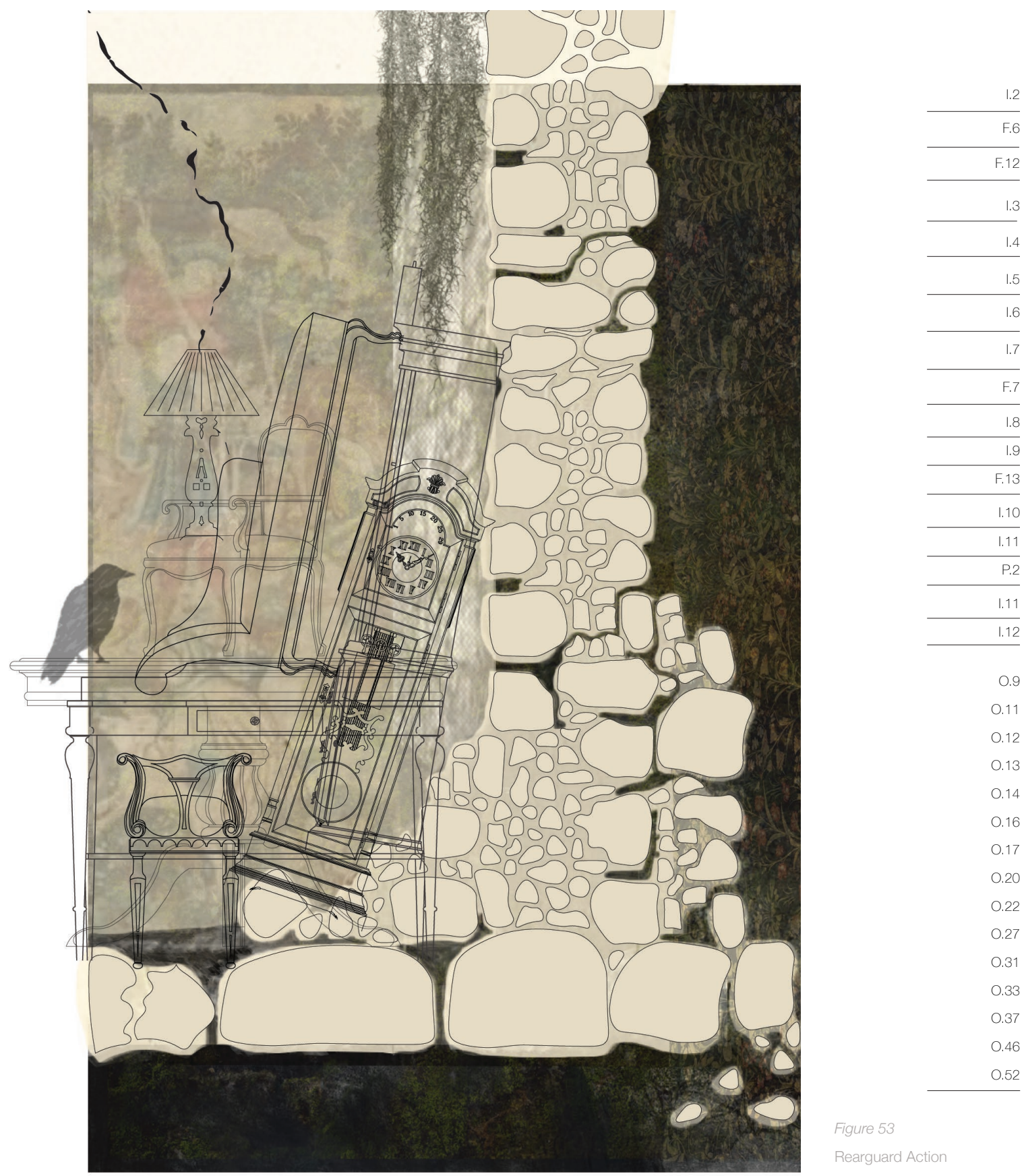

76

Rearguard Action 
The House

External inspection finds the building in overall very poor condition. Part of the roof has collapsed and many of the roof timbers are broken. The roof damage exposes the interior to decay. Foundation walls begin to flood with peat matter from The Moor. The timberwork is in poor condition and in need of repair and maintenance.

The Stravaig

Unsure, he follows the apparition as it glides deeper into the house, losing track of time. The Stravaig finds himself staring down the length of an endless hall, lined with oak panelling, the past framed in figures and flowers in its moulding. The smell of damp is strong, the wooden boards soft and rotted, striated with moss and the wet trails of worms and insects.

At the end of the hall a door is ajar. A light spills out from it. He enters into an elaboratively decorated Drawing Room. Ornate tapestries and art adorn the walls with theatrical and violent hunting scenes. Mounted stags occupy the empty spaces, their antlers reach out from the wall, away from their fastened tartan display. Heavy baroque and Victorian furniture sinks into thick, piled rugs. A large Gothic chair faces out an imposingly large, beautifully paned, stone-framed window. 


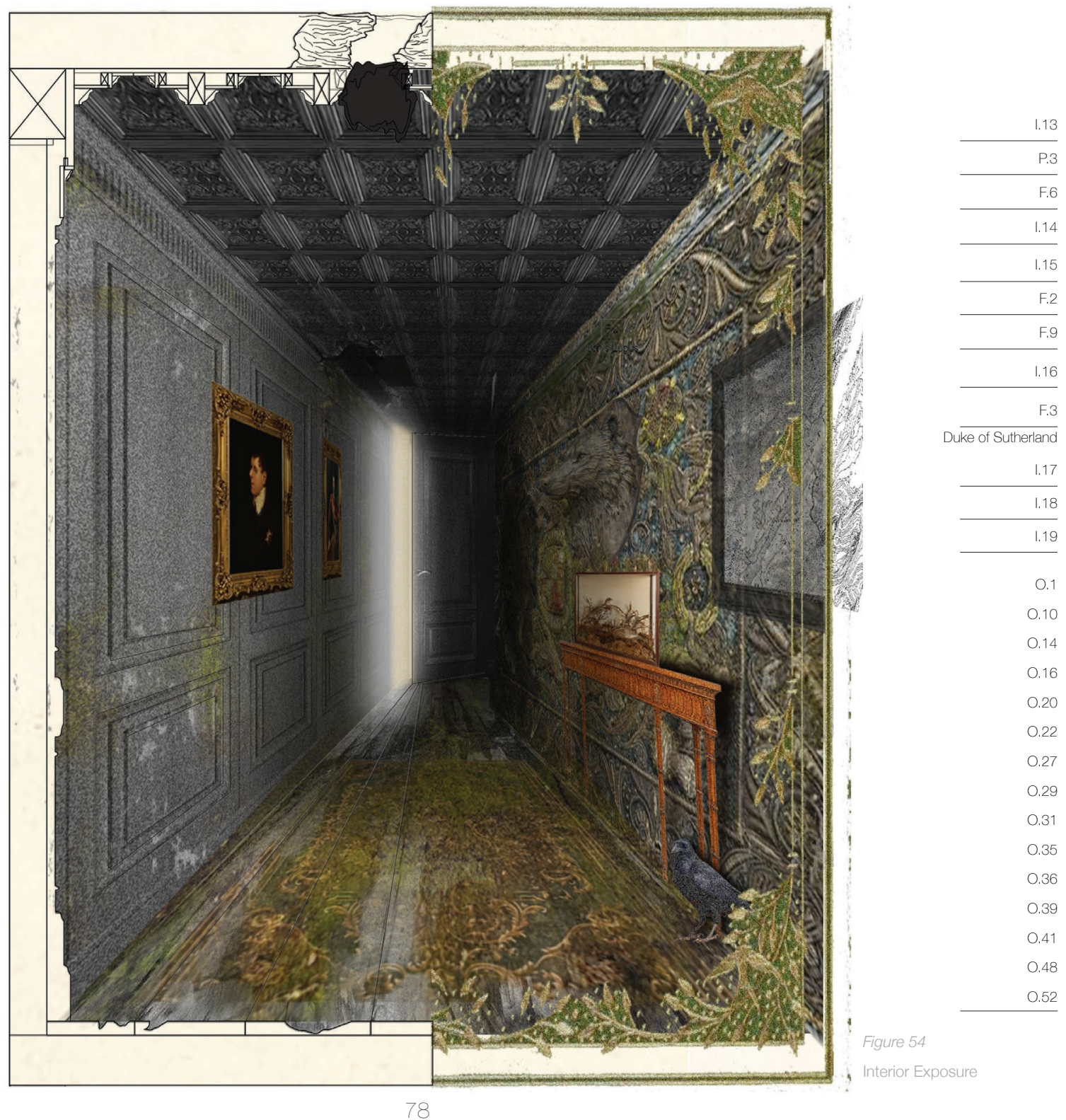




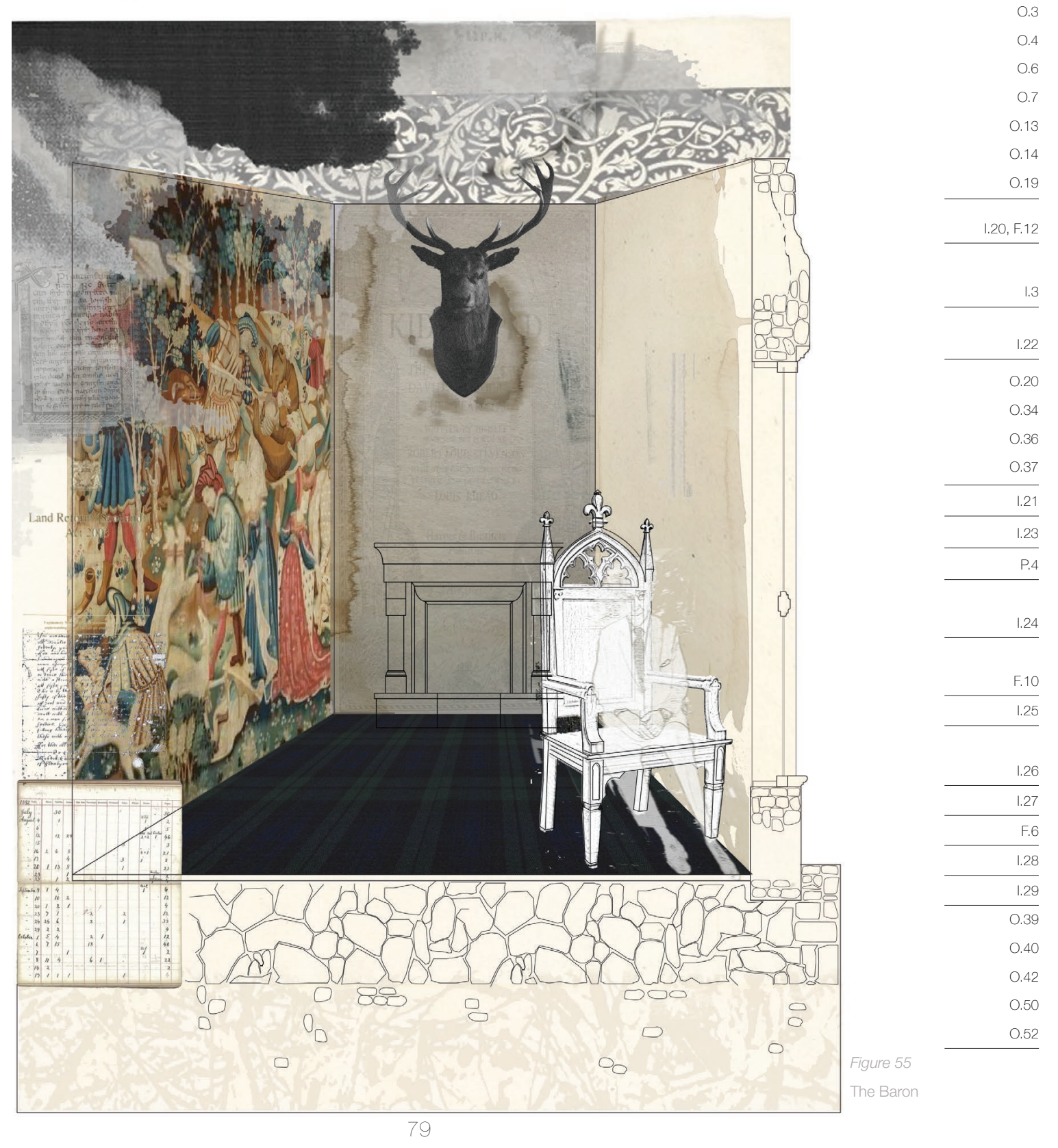




\section{The Baron}

I am losing my mind, here in this dark, surrounded by ghosts. Am I a ghost? Everything that I had is no longer mine. Perhaps the bog will devour me, slowly as the ravens circle above.

My dominion? My Empire? I have lost control, even, of the wolves. All that's left is this house, and the decaying things in it. They, and I, suffocate in dust and damp. Trophies tarnish. We are all Time's mercy. I watch the changing seasons, and watch him change with them, The Hart outside my window. His crown of velvet sheds to sharp, sleek branches for battle. His coat thickens when the frost settles and thins with the spring rain. I see him and he sees me, watching, separated by a pane of glass. He fades into the landscape as if wearing The Moor on his back.

The Baron leans back in his chair, illuminated by the light of a dying fire. Tomorrow he will get up and resume his self-inflicted post, staring out the window onto the vast, endless moor. This is his penance. An ode to The Moor - the "curious volumes of forgotten lore"90. He looks blankly at the doorway. "Are you a wolf or a stag?"

The Moor

Do not think that you, with all your trophies and your crown can escape me.

\section{The Moss}

Moss is a gatherer; collecting imprints of past life, lost footsteps, and rituals.

It gathers absence, recording presence in shallow layers of peat. 


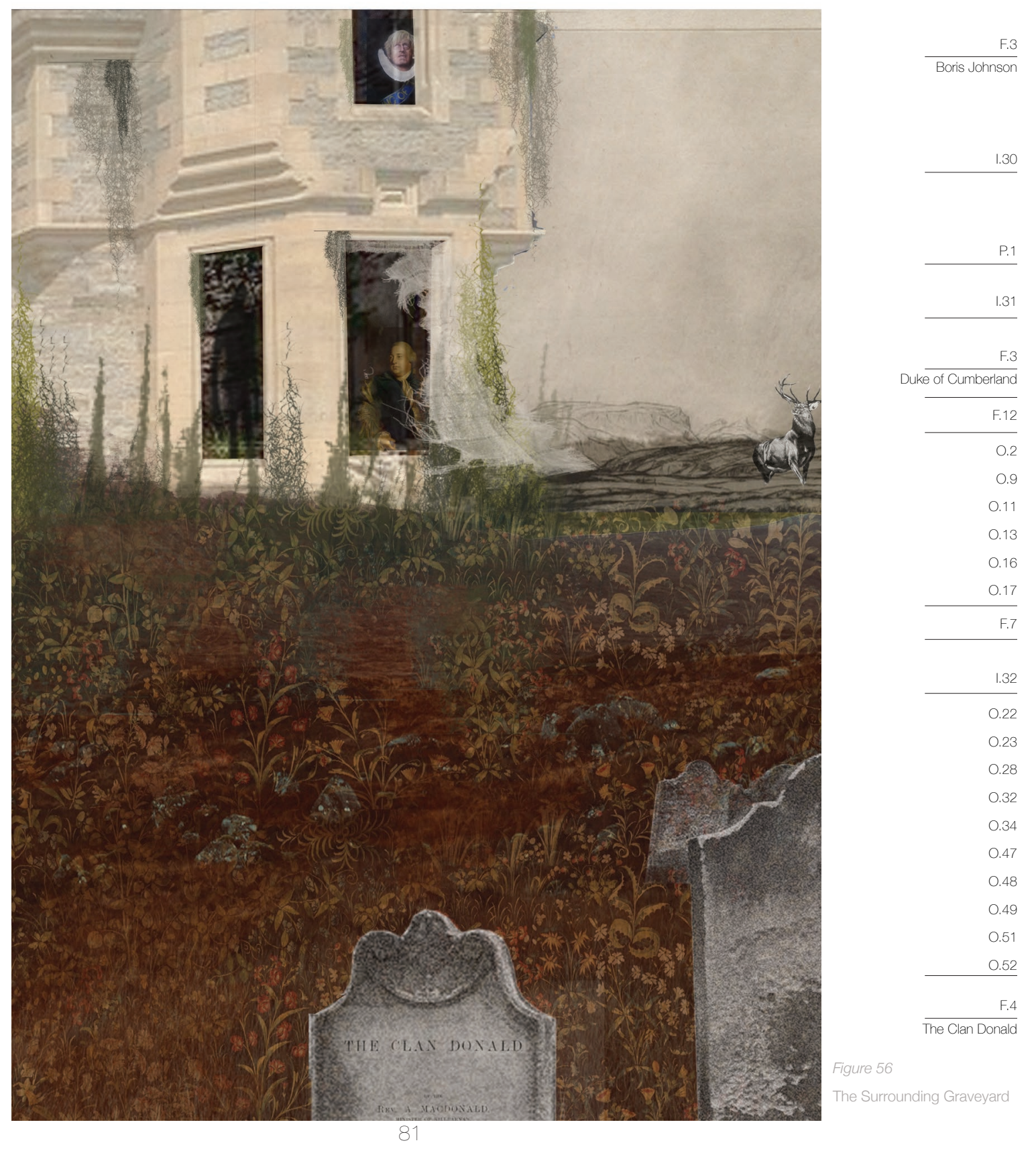


The House

External inspection finds the building in near ruinous condition. Some turrets are still slated but otherwise the roof has been lost. Internal floors are unstable and all windows have been lost. The building is engulfed in moss and the timber beams are in a decayed state. The façade is crumbling and disintegrated. The surrounding graveyard remains in-tact.

The Stravaig

Emerald green moss begins to cover the chair and the walls, inching over tapestries, art and furniture. It carpets the floor and laces the empty window. The fire is extinguished. The room becomes damp, watery. It smells of rain and wet earth. The Stravaig crosses through the window and back out onto The Moor. He notices gravestones as he retreats from the House. He can feel it, falling into the ground. 
Acrotelm (V.16)
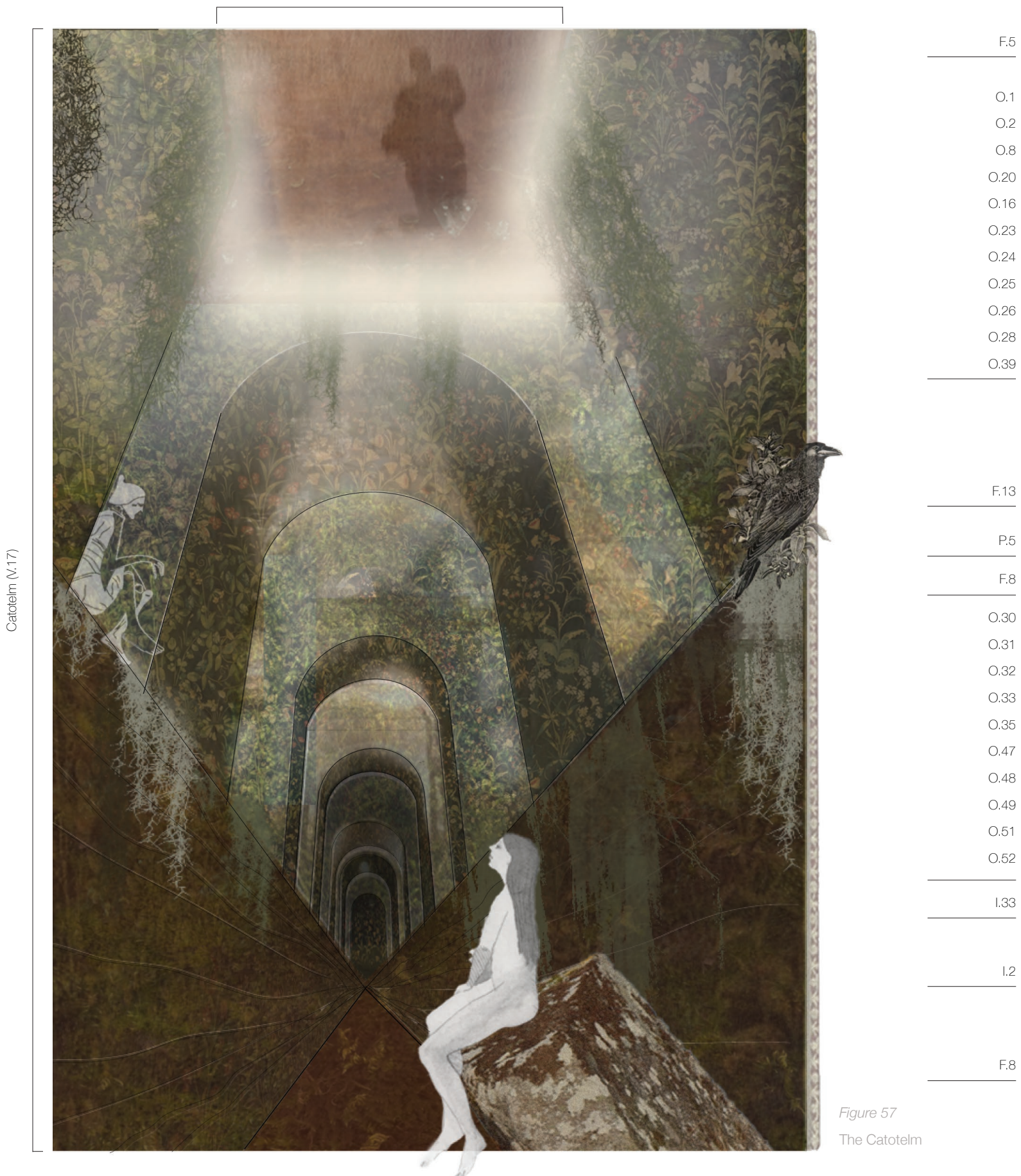

F.13
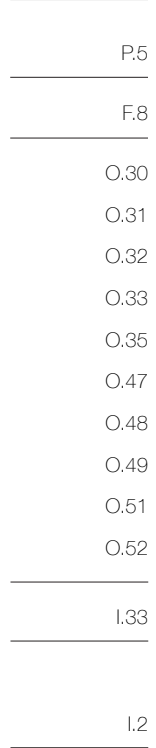

F.8

Figure 57

The Catotelm 
The Body

She inspects her mossy catacomb, tracing her fingers over the faint lines of strata in the ground - delicate wrinkles of time. Like pages in a book. An enchanting, earthy perfume of primeval moss fills the catotelm realm of the non-living. It fills her with memories, of her mother telling stories of the land and creatures that share this earth. Her favourite were the seal folk; the Selkies. Women who lived in the sea as seals, only shedding their skins when they came to shore; living between worlds.

She remembers her other world. The defeat. The Crown's retribution.

That was a different time.

She sees the wanderer up above. He sees her tomb stone, placed in an act of memorial. He looks down as she looks up. It no longer stands upright but lain on a bed of dark rust fabric that coats The Moor. The ground is thin here.

\section{The Moss}

Sphagnum, above all else, remembers.

The Stravaig

Narrowly escaping the collapsing house, the Stravaig turns to watch as the old estate is reclaimed into the moor, bones, histories and all.

He turns and continues, looking for the footpath. Daylight lightens the sky. 


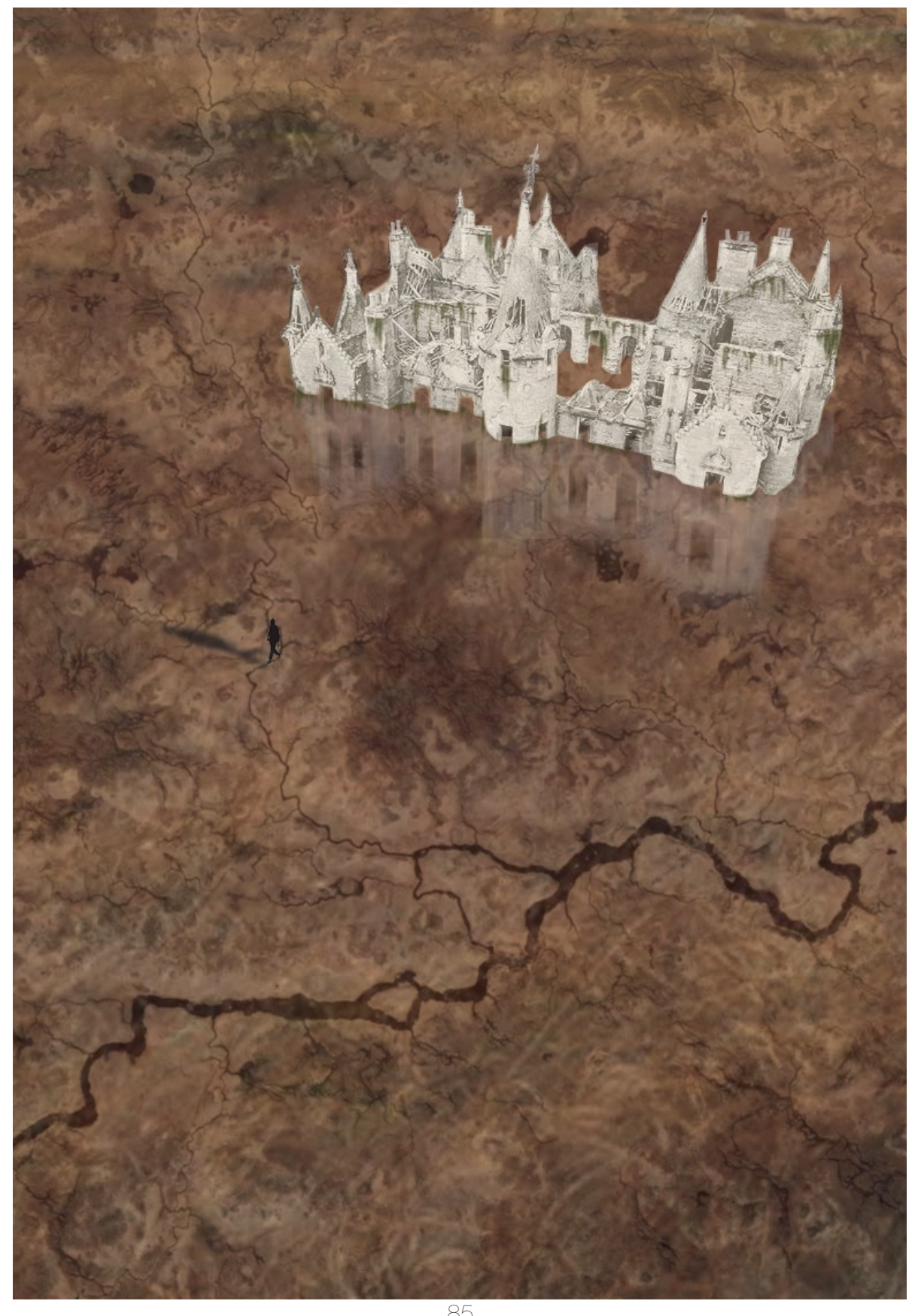

F.13

P.1

F.5 
The House

Condition : Ruinous

The Moor

Ruination is complete. 


\title{
Afterward
}

The Myth

\begin{abstract}
7 he House represents a certain duality - it is at once a monument of an old world and in a process of ruination, collapsing into 1 the moor. The House is a mediation on a world in which various kinds of ruination exist, some as a form of salvation. The Moor consumes the House along with the instability of its creation - decaying empire means perhaps, possibly, a different and emancipated world. It is at once a satire and a tragic-comedy: a tale of demise; of an institution, of a way of life, of a house.
\end{abstract}

The story is inspired by the structures of myth. Figures exist as discarded symbols, movements, transitions, allegories of historical moments, and personified abstractions of place. A metamorphosis occurs, the structure of The House deteriorates, consumed by the natural forces of The Moor. These are the elements of the myth, but what of the myth itself?

This question was posed to me during the discussion in my final defense. It was not about the message or moral of the story, but of the possibility of an enduring imprint, a lasting residue. What were the structural bones of the story that could endure time, past the point in which the characters and allegory no longer hold the same relevance, or the specific symbols have 
faded from memory? I looked towards fables I was familiar with in order to understand the process of untangling meaning from myth. The selkie folk tale, for example, tells a story of an unwilling woman transformed and captured by a male figure. It is a story of the eternal desire to return to a world from which one was taken, of the desire to control something that is not yours to control. These are the frameworks from which the myth is formed; the figures and details shift and deviate over time, through retellings, over different places, from sea to shore. This is the myth's ability to adapt, to endure; it's resiliency lies in its possibility to shift over time, space and memory.

Shift $[\mathrm{verb}]$ - to change or move or
cause to change or move from one
position or state to another ${ }^{91}$

The word shift is of Old English and Germanic origin, rooted in the words sciftan 'to arrange, divide and from schichten which means 'to layer, stratify. ${ }^{92}$ These etymologies embody the very nature of mythos as it can be arranged, divided, rearranged, changed and moved. They can be layered with symbols, information, ideas, and people. The verb shift exists as a state of being, which is applied to the thing, in this case the myth. Based on this understanding, I pondered the shift of my own story. Where was the ability to shift?

91 "Shift, Verb."

92 "Shift, Verb."

93 "Revere, Verb."

In the story of The House and The Moor, the myth lies in a few places. It is in the promise of time taking all things, the fragility of the human in the context of deep-time, of finite human space set against geologic immensity. Time exists in the physicality of the moor, embedded in the moss and peat. It is within the thin place - the contact point between worlds, acknowledging something deeper and older than ourselves. It is not the past, present, or future - it is unfixed, yet still. It is the point at which you meet yourself. It acknowledges and tries to understand our own vulnerability, our fears, our grief, our joy. It holds reverence.

Revere (verb) - to feel deep respect or admiration ${ }^{93}$. 
From the French révérer or Latin

revereri, the root being vereri which

means to feel awe of, or to fear ${ }^{94}$.

The deep time and thinness of our existence provide the myth motifs through which the story is able to shift. It is how I imagine the story to continue to exist in a century or millennia from now, taking on different places, figures, and operations. As the myth resists completion, so too does this thesis. It is a marker on a pathway that has no definitive direction, yet provides stability while moving towards something unknown. There are registers - constants - in the thesis, like the 'brooms' that guide passage out on the tidal path of the Broomway in Macfarlane's Old Ways (see Fig. 59); markers that allow a seemingly directionless place to become tethered on a path that is "... is swept clean of the trace of passage twice daily by the tide." 95 Of this, Macfarlane asks, "What is a path that is no path?" ${ }^{6}$ Like the water that makes the Broomway, the shifting tide changes our landmarks.

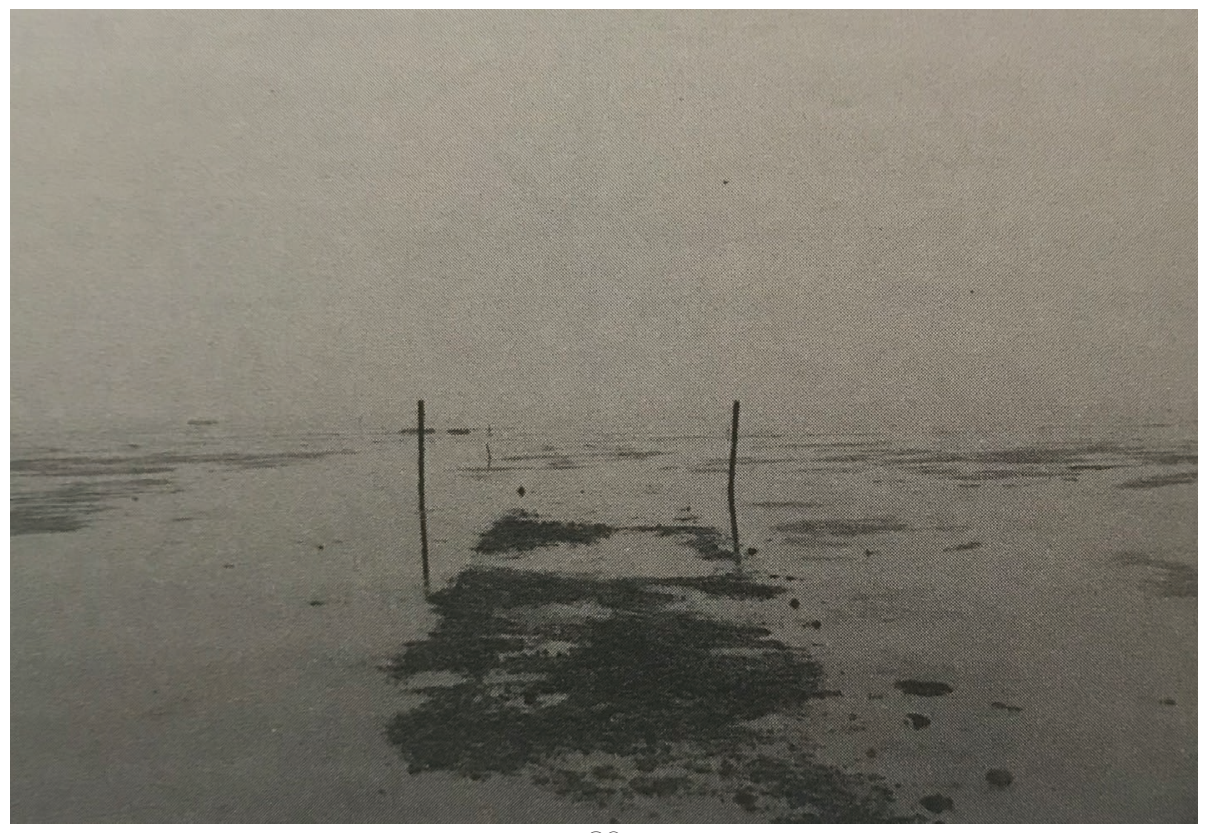




\section{The Language}

"Can you talk about the importance of language within your work?"

This question was also posed during the final defense, and one I feel deserves a little space here in these afterthoughts. It became increasingly evident to me that the way in which we describe, identify, and acknowledge spaces and places is intrinsically linked to language. Language grabs our attention, engages us, and enables the complexity of the conditions that surround us to become deeper and clearer through description. Words are linked to place, poetically denoting aspects and details, and are also deeply 97 Macfarlane, Landmarks, 98 Macfarlane, 6. denotative and functional. One hundred words for rain are less likely to exist in the desert. Perhaps one hundred words for sand or stars. Macfarlane notes in his book Landmarks the profound relationship between words and the non-human elements of our world, and the competence, empathy and understandings that grow from this connection. Words seek to give meaning and illuminate understanding. They leave traces in literature, stories, and language through their etymology. Macfarlane uses the example of the verb to consider, its root from the Latin con-siderare which means 'to study or see with stars', "...a mundane verb is suddenly starlit."97 By tracking their origins, meanings and possibilities shift into wonderous new directions. Macfarlane calls these "tiny poems that conjure scenes."98 
Given the ability of architecture to create worlds and scenes through narrative and construction, the ability to describe and 'conjure' them would seem non-negotiable. As Macfarlane points out the importance of language to reconnect and re-imagine our relationship with the earth, could architecture not also apply this to the design of spaces? A discipline known for buzzwords, could there be a more nuanced approach that enables us to connect more vividly or harmoniously to our spaces? As the gaelic prahse rionnach maiom describes the shadow of a cloud over the moor on a sunny day, could there not be a word that captures the shadow cast by a building of a certain height? In cities where towers rule, should we not be able to describe in detail the conditions they create?

These thoughts have embedded themselves my mind, opening up different possibilities and pathways of inquiry. My thesis pursued the notion of how architecture describes the world - but in doing so I have found myself asking 'how do I describe the world?' 
Thank You

Tapadh Leibh 


\section{Bibliography}

"Abolition of Feudal Tenure Etc. (Scotland) Act 2000." Scottish Government. Accessed November 4, 2020. https://www.legislation.gov.uk/asp/2000/5/contents.

Agus, Fahmuddin. Measuring Carbon Stock in Peat Soils: Practical Guidelines. Bogor, Jawa Barat, Indonesia: World Agroforestry Centre, 20 or.

Andrews, Travis M. "Man Finds 22-Pound Chunk of Butter Estimated to Be More than 2,ooo Years Old in Irish Bog." Washington Post. Accessed November 4, 2020. https://www.washingtonpost.com/news/morning-mix/wp/2016/06/14/manfinds-22-pound-chunk-of-butter-estimated-to-be-more-than-20oo-years-oldin-irish-bog/.

The Pritzker Architecture Prize. "Anne Lacaton and Jean-Philippe Vassal| The Pritzker Architecture Prize." Accessed March 3I, 202I. https://www.pritzkerprize.com/ laureates/anne-lacaton-and-jean-philippe-vassal.

Armbrecht, Ann. Thin Places: A Pilgrimage Home. Columbia University Press, 20o8. https:// doi.org/10.73I2/armbi4652.

Armitt, Lucie, and Lucie Armitt. Twentieth-Century Gothic. History of the Gothic 3. Cardiff: Univ. of Wales Press, 20Ir.

Atkins, William. The Moor: Lives, Landscape, Literature. London: Faber \& Faber, 2014.

Barber, Katherine, ed. "Curious, Adj." In Canadian Oxford Dictionary. Don Mills, Ontario: Oxford Univ. Pr, 2004.

Berkes, Fikret. Sacred Ecology. 3rd ed. New York: Routledge, 20 2.

Bernheimer, Kate, Andrew Bernheimer, and Radic. "Fairy Tale Architecture: Gripho."

Places Journal, no. 2016 (December 2I, 2016). https://doi.org/Io.22269/I6I22I.

Black, Ronald, ed. An Lasair: Anthology of 18th Century Scottish Gaelic Verse. Edinburgh: Birlinn, 200I.

Blaikie, Andrew. The Scots Imagination and Modern Memory. Edinburgh University Press, 2010. https://doi.org/10.3366/edinburgh/9780748617869.001.000I.

"Blashy Adj." In Dictionary of the Scots Language. Scottish Language Dictionaries Ltd, 2004. https://www.dsl.ac.uk/entry/snd/blashy.

"Brexit - Gov.Scot." Accessed January II, 202I. https://www.gov.scot/brexit/.

Bruneau, P.M.C, and S.M. Johnson. "Scotland's Peatland - Definitions and Information Resources." Scottish Natural Heritage Commissioned Report No 70I., 2014. 
Bryden, John, and Charles Geisler. "Community-Based Land Reform: Lessons from Scotland." Land Use Policy 24, no. I (January 2007): 24-34. https://doi.org/Io.Ior6/j. landusepol.2005.09.004.

Buildings at Risk Registar for Scotland. "Dunalastair House, Kinloch Rannoch." Register, n.d. https://www.buildingsatrisk.org.uk/details/893475.

Burns, John D. Bothy Tales: Footsteps in the Scottish Hills, 2019.

Burns, Robert, and May Kramer-Muirhead. Tam O'Shanter. [Corte Madera, CA: ANRO Communications], 1984 .

Butlin, Ron. Little Book of Scottish Rain. Place of publication not identified: BIRLINN LTD, 2018.

Carrell, Severin. "Scottish Village Buys Large Part of Langholm Moor from Duke of Buccleuch." The Guardian, November 2, 2020, sec. UK news. http://www. theguardian.com/uk-news/2020/nov/o2/scottish-village-langholm-moor-dukeof-buccleuch.

Castree, Noel. "The Production of Nature." In A Companion to Economic Geography, 275-89. John Wiley \& Sons, Ltd, 2017. https://doi.org/10.1002/9781405166430.ch17.

Cathcart, Alison. "The Statutes of Iona: The Archipelagic Context." Journal of British Studies 49, no. I (January 2010): 4-27. https://doi.org/I0.1086/644533.

Clark, Domini. "A Spooky Scottish Story Straight out of Outlander - The Globe and Mail." The Globe and Mail, 20I8. https://www.theglobeandmail.com/life/travel// article-hiking-across-scotlands-rannoch-moor-will-leave-you-questioningwhat/.

Cooper, Susan, and Warwick Hutton. The Selkie Girl. ist ed. New York: M.K. McElderry Books, 1986 .

Cronon, William J. "The Trouble with Wilderness; or, Getting Back to the Wrong Nature," n.d., 24.

Cunha, Dilip da. River Vs Rain Dilip Da Cunha. Lecture. Columbia University, 2018. https://www.arch.columbia.edu/events/804-river-vs-rain-dilip-da-cunha.

Cunningham, A.D. A History of Rannoch Moor. The Shed Gallery, Kinloch Rannoch, 1989. - - . Tales of Rannoch. The Shed Gallery, Kinloch Rannoch, 1989.

Davidson, John. "Magnus Davidson Becomes Youngest Member of Community Land Scotland Board." JohnOGroat Journal, March 7, 2021, sec. Latest News. https:/www.johnogroat-journal.co.uk/news/far-north-man-joins-board-of- 
community-ownership-group-2303gi/.

Deutinger, Theo, and Brendan McGetrick. Handbook of Tyranny. Zürich: Lars Müller Publishers, 2018.

Devine, T. M. The Scottish Clearances: A History of the Dispossessed, 1600-19oo. UK: Allen Lane an imprint of Penguin Books, 2018.

"Dictionary of the Scots Language." Accessed January I8, 202I. https://dsl.ac.uk/aboutdsl/.

Doyle, Arthur Conan. The Hound of the Baskervilles. New York, N.Y.: Viking/Penguin Young Readers Group, 2004.

Dyakonov, K. N., E. Yu. Novenko, N. G. Mazei, and M. V. Kusilman. "The Age of Peatlands and Peatland Formation Stages in Polesie Landscapes of the East European Plain." Doklady Earth Sciences 492, no. 2 (June 2020): 464-7o. https:// doi.org/IO.II34/SIO28334X20060069.

Estate Exchanges. "Estate Exchange, No. I518 Sales Brochure." Canmore: National Record of the Historic Environment, I890. https://canmore.org.uk/site/2509I/ dunalastair.

"EU Referendum Results - BBC News." Accessed January II, 202I. https://www.bbc.co.uk/ news/politics/eu_referendum/results.

"Europe's Famed Bog Bodies Are Starting to Reveal Their Secrets | Science | Smithsonian Magazine." Accessed November 4, 2020. https://www.smithsonianmag.com/ science-nature/europe-bog-bodies-reveal-secrets-I80962770/.

Fenton, Alexander. Scottish Country Life. Edinburgh: Donald, I976.

Flanagan, Mike. "The Romance of Certain Old Clothes." The Haunting of Bly Manor. Netflix, October 9, 2020.

Fletcher, Susan. Corrag. London: Fourth Estate, 2oro.

Frearson, Amy. "We Banned Renders' from the Design Process Says Tatiana Bilbao." Dezeen, December 4, 2019. https://www.dezeen.com/20Ig/I2/o4/tatiana-bilbaobanned-renderings-architecture-interview/.

Gaiman, Neil. "Introduction." In Fahrenheit 451, by Ray Bradbury. New York: Simon \& Schuster, 2012.

Gairn, Louisa. Ecology and Modern Scottish Literature. Edinburgh: Edinburgh University Press, 2008. http://site.ebrary.com/id/I0405I6I. 
Ghosh, Amitav. The Great Derangement: Climate Change and the Unthinkable. Paperback edition. The Randy L. and Melvin R. Berlin Family Lectures. Chicago London: The University of Chicago Press, 2017.

Goodare, Julian. "The Statutes of Iona in Context." The Scottish Historical Review 77, no. I (April 1998): 31-57. https://doi.org/I0.3366/shr.1998.77.I.31.

"Goselet n." In Dictionary of the Scots Language. Scottish Language Dictionaries Ltd, 2004.

Grant, Kevin James. "'And in Every Hamlet a Poet': Gaelic Oral Tradition and Postmedieval Archaeology in Scotland." Historical Archaeology 48, no. I (2014): 30-45.

Hall, Stuart. "Constituting an Archive." Third Text 15, no. 54 (March 2001): 89-92. https:// doi.org/10.1080/09528820108576903.

Handa, Rumiko, James J. Potter, and Iain Borden, eds. Conjuring the Real: The Role of Architecture in Eighteenth- and Nineteenth-Century Fiction. Lincoln: University of Nebraska Press, 20II.

Haraway, Donna Jeanne. Staying with the Trouble: Making Kin in the Chthulucene. Experimental Futures: Technological Lives, Scientific Arts, Anthropological Voices. Durham: Duke University Press, 2016.

Hewitt, Rachel. Map of a Nation: A Biography of the Ordnance Survey. London: Granta, 2010.

Hoad, T.F., ed. "Revere, Verb." In The Concise Oxford Dictionary of English Etymology. Oxford University Press, 2003.

_-_, ed. "Shift, Verb." In The Concise Oxford Dictionary of English Etymology. Oxford University Press, 2003.

Holmes, Rob. "The Problem with Solutions." Places Journal, no. 2020 (July I4, 2020). https://doi.org/10.22269/2007I4.

RAMSAR. "Homepage | Ramsar." Accessed March 29, 202r. https://www.ramsar.org/.

Institute, Swiss. Lecture / Jason W. Moore on Our Capitalogenic World: Humanity, Nature, and the Making of a Planetary Crisis, 2017. https://vimeo.com/226581628.

Jamie, Kathleen. Findings: Essays on the Natural and Unnatural World. Saint Paul, Minn: Graywolf Press, 2007.

-_- Surfacing. New York: Penguin Books, 2019.

"Land Reform (Scotland) Act 2003." Scottish Parliament, 2003.

Registers of Scotland. "Land Register of Scotland." Accessed January II, 202I. https:// www.ros.gov.uk/our-registers/land-register-of-scotland. 
Lutsky, Karen, and Sean Burkholder. "Curious Methods." Places Journal, May 23, 2017. https://doi.org/I0.22269/170523.

Macfarlane, Robert. Landmarks. London: Penguin Books, 2016.

-_- . The Old Ways: A Journey on Foot. London]: Penguin Books, 2013.

- - . The Wild Places. New York: Penguin Books, 2008.

- - Underland: A Deep Time Journey. UK: USA: hh | Hamish Hamilton an imprint of Penguin Books, 2019.

Macfarlane, Robert, Stanley Donwood, Dan Richards. Ghostways: Two Journeys in Unquiet Places. First American edition. New York, NY: W.W. Norton \& Company, 2020.

Mackenzie, A. Fiona D. "A Working Land: Crofting Communities, Place and the Politics of the Possible in Post-Land Reform Scotland." Transactions of the Institute of British Geographers 31, no. 3 (2006): 383-98.

Mackinnon, Iain. "Colonialism and the Highland Clearances." Northern Scotland 8, no. I (May 2017): 22-48. https://doi.org/I0.3366/nor.2017.0125.

Madrigal, Alexis. "Bogosphere: The Strangest Things Pulled Out of Peat Bogs." Wired. Accessed March I0, 202I. https://www.wired.com/2009/o8/bogosphere/.

Maguire, Gregory, and Kate Bernheimer. My Mother She Killed Me, My Father He Ate Me: Forty New Fairy Tales. New York: Penguin Books, 20I4. http://rbdigital. oneclickdigital.com.

Manguel, Alberto, and Gianni Guadalupi. The Dictionary of Imaginary Places. Newly updated and Expanded. New York: Harcourt Brace, 2000.

Mathur, Anuradha, and Dilip da Cunha. "Wetness Is Everywhere: Why Do We See Water Somewhere?" Journal of Architectural Education 74, no. I (January 2, 2020): I39-40. https://doi.org/Io.1080/10464883.2020.1693843.

McDonnel, Alec. "Scottish Independence Polling." Accessed January II, 202I. https://yougov.co.uk/topics/politics/articles-reports/2020/II/I2/scottishindependence-yes-51-49-no.

McGregor, James. "THE ARCHITECT AS STORYTELLER: Making Places in John Hedjuk's Masques." Architectural Theory Review 7, no. 2 (November 2002): 59-70. https://doi.org/10.1080/13264820209478457.

McKenna, Kevin. "Scotland Has the Most Inequitable Land Ownership in the West. Why?" The Guardian, August Io, 20I3. http://www.theguardian.com/uknews/20r3/aug/ro/scotland-land-rights.

Milton, John. Paradise Lost, 2017. 
MRS. ANN GLOAG v. PERTH AND KINROSS COUNCIL+THE RAMBLERS ASSOCIATION (Sheriffdom of Tayside Central and Fife at Perth June I2, 2007).

"National Life Tables - Life Expectancy in the UK - Office for National Statistics." Office for National Statistics, 2020. https:/www.ons.gov.uk/ peoplepopulationandcommunity/birthsdeathsandmarriages/lifeexpectancies/ bulletins/nationallifetablesunitedkingdom/20I7to20Ig.

Parnell, Edward. Ghostland: In Search of a Haunted Country. London: William Collins, an imprint of HarperCollins Publishers, 2019.

Participation, Expert. "Scotland Act 1998." Text. Statute Law Database. Accessed November 4, 2020. https://www.legislation.gov.uk/ukpga/1998/46/section/30.

Patel, Raj, and Jason W. Moore. A History of the World in Seven Cheap Things: Guide to Capitalism, Nature, and the Future of the Planet. University of California Press: Oakland, California, 2017.

Perry, Dennis R., and Carl Hinckley Sederholm. Poe, "The House of Usher," and the American Gothic. Ist ed. New York: Palgrave Macmillan, 2009.

Poe, Edgar Allan, and C. H. Sisson. The Raven : Poems and Essays on Poetry. Manchester, UNITED STATES: Carcanet Press Ltd., 20I4. http://ebookcentral.proquest. com/lib/oculcarleton-ebooks/detail.action?docID=I66rogr.

Rannoch Visitors Centre. "Building the West Highland Line." Rannoch Rail Station, November 2020.

"Roy Military Survey of Scotland, I747-I755 - National Library of Scotland." Accessed November 4, 2020. https://maps.nls.uk/roy/originals.html.

Saadi, Suhayl. "Songs of the Village Idiot: Ethnicity, Writing and Identity." Third Text 2I, no. 5 (September 2007): 589-97. https://doi.org/I0.I080/0952882070I599727.

Sanders, Scott Russell. "The Power of Stories." The Georgia Review 5I, no. I (I997):

II $3-26$.

Schama, Simon. Landscape and Memory. Ist ed. New York: A.A. Knopf: Distributed by Random House, I995.

"Scottish Government Gaelic Language Plan 2016-202r." The Scottish Government, May 2017. https://www.gaidhlig.scot/en/gaelic-language-plans/the-national-gaeliclanguage-plan/

Visit Scotland. "Scottish Highlands Holidays \& Things To Do." Accessed January 8, 2O2I. 
https:/www.visitscotland.com/destinations-maps/highlands/.

"Scottish Independence Referendum - Results - BBC News." Accessed January II, 202I. https://www.bbc.co.uk/news/events/scotland-decides/results.

Shepherd, Nan. The Living Mountain: A Celebration of the Cairngorm Mountains of Scotland. Edinburgh: Canongate, 20II. http://www.vlebooks.com/vleweb/product/ openreader?id $=$ Aberdeen\&isbn $=9780857863607$.

Simpkins, Fiona. "Twenty Years of Devolution in Scotland: The End of a British Party System?" Revue Française de Civilisation Britannique XXIV, no. 4 (November I8, 2019). https://doi.org/10.4000/rfcb.4938.

Simpson, Ted. The Cull: Scotland's Deer Dilemna. Documentary, 2020.

"Spindrift n." In Dictionary of the Scots Language. Scottish Language Dictionaries Ltd, 2004.

Staff, Guardian. "Hallaig by Sorley MacLean, Translated by Seamus Heaney." The Guardian, November 30, 2002, sec. Books. https://www.theguardian.com/books/2002/ nov/30/featuresreviews.guardianreview35.

"Statutes of Iona | Exploring Celtic Civilizations." Accessed November 4, 2020. http:// exploringcelticciv.web.unc.edu/statutes-of-iona/.

Stevenson, Robert Louis, and Ian Duncan. Kidnapped. Oxford World's Classics. Oxford: Oxford University Press, 20I4.

"The Land of Scotland and the Common Good: Report - Gov.Scot." The Scottish Government, May 20I4. https:/www.gov.scot/publications/land-reformreview-group-final-report-land-scotland-common-good/pages/86/.

The Oxford Scottish song book: sixty songs for unison or solo singing with piano. London: Oxford University Press, 1969 .

Turetsky, Merritt R., Sturt W. Manning, and R. Kelman Wieder. "Dating Recent Peat Deposits." Wetlands 24, no. No.2 (2004): 324-56. https://doi.org/I0.1672/0277$52 \mathrm{I} 2(2004)$

"UK Climate Change Risk Assessment 2017 Evidence Report -Summary for Scotland." Committee on Climate Change, 2017.

Wightman, Andy. The Poor Had No Lawyers: Who Owns Scotland and How They Got It, 2013.

Withers, Charles W. J. "Place, Memory, Monument: Memorializing the Past in Contemporary Highland Scotland." Ecumene 3, no. 3 (July 1996): 325-44. https:// doi.org/I0.II77/I474447409600300304. 
Womack, Peter. Improvement and Romance: Constructing the Myth of the Highlands. Language, Discourse, Society. Houndmills, Basingstoke, Hampshire: Macmillan, I989.

Wright, Peter. "So What Is the Watershed? | Ribbon of Wildness." Ribbon of Wildness (blog), August 22, 20Iо. http://www.ribbonofwildness.co.uk/watershed. 